\title{
GOBIERNO MUNICIPAL Y VENTA DE OFICIOS EN LA ASTURIAS DE LOS SIGLOS XVI Y XVII
}

por

\author{
M. ÁNGELES FAYA DÍAZ \\ Universidad de Oviedo
}

RESUMEN: Los Austrias utilizaron de modo continuado la venta de oficios con el fin de conseguir recursos para su política hegemónica. A través del análisis de este expediente bemos podido establecer las graves consecuencias que trajo tanto desde un punto de vista económico-social como político y la oposición institucional y social que generó. El proceso de patrimonialización de lo público y de oligarquización de la vida municipal propició abusos y corrupción, produciendo la degradación más completa de la institución municipal. Para la capa más alta de la nobleza supone una afirmación de su poder y una dignificación como clase. La nobleza responde a sus ansias de riqueza y poder invirtiendo en cargos, señoríos y alcabalas que la Corona vende.

Mientras los Austrias obtienen unos 300.000 ducados por la venta de oficios, la inversión en bienes improductivos y la inmobilización de capitales de la nobleza es una causa de que no se cree riqueza en Asturias. El gasto de la clase dominante en adquisición de bábitos y títulos así como su lujo y ostentación, actúan en el mismo sentido. Además, los costes de pleitos, tanteo y consumo de cargos produjo el endeudamiento de los municipios asi como, junto con otras formas de presión fiscal, un coste social importante.

Palabras clave: Gobierno municipal. Oficios. Nobleza. Asturias. Corona de Castilla.

ABSTRACT: The kings of the Austria dynasty used widely the sale of officess with the purpose of arbitrating resources for their hegemonical politics. Through the analysis of this sales we have been able to settle down the serious economic and social consequences they brought as well as the institutional opposition generated.

The process of patrimonialization of the public thing and the oligarchic way taken by the municipalities propitiated abuses and corruption, causing the complete degradation of the municipal institution. For the highest layer of the nobility, it supposed a statement of their power and his dignificacion as a class. To satisfy their longings of power the nobility will invest in offices, dominions and taxes ("alcabalas») sold by the kings. 
While the Crown obtains about 300.000 ducados from the sale of offices, the investment in unproductive goods and the inmobilization of the capitals of the nobility caused a lack of wealth creation in Asturias. The expense of the dominant class adquiring babits and titles as well as his luxury and ostentation, they act in the same sense. In addition, the costs of cases, rescues and consumption of offices produced the indebtedness of the municipalities and, together with other forms of fiscal pressure, an important social cost.

KEY WORDS: Municipal government. Offices. Nobility. Asturias. Crown of Castile.

Este estudio responde a un objetivo prioritario: analizar uno de los expedientes arbitrados por los Austrias para obtener recursos y evaluar las consecuencias que trajo sobre la sociedad asturiana tanto desde un punto de vista socioeconómico como político. Anteriormente ya hemos analizado otro de los arbitrios utilizados, la venta de jurisdicciones eclesiásticas y las repercusiones tan importantes que tuvo en la Asturias de finales del siglo XVI ${ }^{1}$. Pretendemos ahora abordar la venta de oficios municipales que la Corona va a llevar a cabo en el Principado desde los años cuarenta del siglo XVI hasta avanzado el siglo siguiente. El tema es aún escasamente conocido, los estudios son parciales e insuficientes y es necesario un estudio general ${ }^{2}$. El incremento del intervencio-

1 FAYA DíAZ, Mª A.: Los señoríos eclesiásticos en la Asturias del siglo XVI, Oviedo, 1992.

${ }^{2}$ El tema de la venta de oficios en la Corona de Castilla ha merecido la atención de diversos historiadores. Debemos citar los estudios de DOMínGuez ORTIZ, A.: «La venta de cargos y oficios públicos en Castilla y sus consecuencias económicas y sociales», en Anuario de Historia Económica y Social, 3 (1975) y «Poder estatal y poder municipal en Castilla bajo los Austrias», en Centralismo y descentralización. Modelos y procesos históricos en Francia y en España, Madrid, 1985; TOMÁS Y VALIENTE, F.: «Las ventas de oficios de regidores y la formación de oligarquías urbanas en Castilla, s. XVIIXVIII", en Actas de las I Jornadas de Metodología aplicada de las Ciencias Históricas, t. III, Santiago, 1975 y Gobierno e instituciones en la España del Antiguo Régimen, Madrid, 1985; GONZÁlez AlonSO, B.: «Sociedad urbana y gobierno municipal en Castilla (1450-1600)», en Sobre el Estado y la administración de la Corona de Castilla en el Antiguo Régimen, Madrid, 1981, "Notas sobre los acrecentamientos de oficios en los municipios castellanos hasta fines del siglo XVI», Centralismo y autonomismo en los siglos XVI-XVII, en Homenaje al profesor Jesús Lalinde Abadía, Barcelona, 1989 y «Peripecias de los oficios municipales en la Castilla de Felipe II", en RiBOT GARCíA, L.A.: La monarquía de Felipe II a debate, Valladolid, 1999; CUARTAS, M.: «La venta de oficios públicos en el s. XVI», en Actas del IV Symposium de Historia de la Administración, Madrid, 1983 y «La venta de oficios públicos en CastillaLeón en el s. XVI», en Hispania, 158 (1984); GeLABERT, J.E.: "Tráfico de oficios y gobierno de los pueblos en Castilla (1543-1643), en RiBOt, L.A. (dir.): Ciudad y mundo urbano en la Época Moderna", Madrid, 1997, entre otros. Se estudia el tema en un contexto más general en DoMínGUEZ ORTIZ, A.: Política fiscal y cambio social en la España del s. XVII, Madrid, 1984; GELABERT, I.E.: La bolsa del rey. Rey, reino y fisco en Castilla (1598-1648), Barcelona, 1997; FORTEA, I.: Monarquía y Cortes en la Corona de Castilla. Las ciudades ante la política fiscal de Felipe II, Salamanca, 1990; y GARCÍA SANZ, A.: "Castilla, 1580-1650: crisis económica y política de reformación», en La España del Conde-Duque de Olivares, Valladolid, 1987.

Hispania, LXIII/1, núm. 213 (2003) 75-136 
nismo regio en el régimen municipal, apelando al derecho de regalía que le faculta para acrecentar y perpetuar oficios, está motivado sobre todo por las necesidades de la hacienda real y, en último extremo, por los imperativos de la política exterior.

La venta de cargos tuvo lugar en casi todos los países europeos durante los siglos XVI y XVII. Desde un punto de vista comparativo se le ha concedido más relevancia a este fenómeno en Francia, mientras se han minimizado y desatendido las enajenaciones llevadas a cabo en la Corona de Castilla, donde no sólo se vendieron oficios municipales sino muchos y relevantes cargos de la administración central, sobre todo en el siglo XVII. Además, la importancia que tienen los poderes locales, últimamente resaltada a través de diversos estudios $^{3}$, nos exige un análisis minucioso y una valoración sobre las consecuencias de las ventas en la vida local. Este expediente es clave para entender la formación de las oligarquías municipales y, por tanto, un mecanismo básico para comprender las relaciones de dominación en el Antiguo Régimen.

Por tanto, uno de los objetivos perseguidos es identificar y definir la élite provincial y las élites locales del Principado, que son quienes compran los cargos a la Corona. La aplicación de este arbitrio va a traer la patrimonialización y la oligarquización de los gobiernos municipales. Pero además, puesto que el poder económico y el poder político están íntimamente unidos, queremos profundizar en esas relaciones. La compra de cargos es solamente uno de los aspectos a tener en cuenta en un análisis global sobre las estrategias y el comportamiento económico seguidas por las principales familias del Principado. En este sentido, este trabajo forma parte de un proyecto más amplio sobre la nobleza asturiana, aún muy poco conocida ${ }^{4}$. Las características de un tema tan complejo

3 Así últimamente hay que destacar, entre otros: MARcos Martín, A.: «Oligarquías urbanas y gobiernos ciudadanos en la España del siglo XVI», en BELENGUER, E. (coord.): Felipe II y el Mediterráneo, vol. II, Madrid, 1999; Hernández, A.: A la sombra de la Corona. Poder local y oligarquía urbana, Madrid, 1995; GUerrero MAYllo, A.: El gobierno municipal de Madrid (1560-1606), Madrid, 1993; BURGOS ESTEBAN, F.M.: Los lazos del poder. Obligaciones y parentesco en una élite local castellana en los siglos XVI y XVII, Valladolid, 1994; PORRES MARIJUÁN, R.: Las oligarquías urbanas de Vitoria entre los siglos XV y XVIII: poder, imagen y vicisitudes, Vitoria, 1994; CHACÓN, F. y HERNÁNDEZ FRANCO, J. (eds.): Familia, poderosos y oligarquías, Murcia, 2001; VV.AA.: Oligarquías y municipio en la España de los Austrias, monográfico de Revista de Historia Moderna. Anales de la Universidad de Alicante, 19 (2001); THOMPSON, I.A.A., "Patronato real e integración política en las ciudades castellanas bajo los Austrias», en FORTEA, J.I.: Imágenes de la diversidad. El mundo urbano en la Corona de Castilla (s. XVI-XVIII), Santander, 1997. Entre los numerosos estudios referentes a la Baja Edad Media hay que citar últimamente la obra coordinada por J.A. Bonachía: La ciudad medieval Aspectos de la vida urbana en la Castilla Bajomedieval, Valladolid, 1996; el monográfico Oligarquías políticas y élites económicas en las ciudades bajomedievales (siglos XIV-XVI), Revista d'Història Medieval, Valencia, 1998 y el estudio de JARA FUENTE, J.A.: Concejo, poder y élites. La clase dominante de Cuenca en el siglo XV, Madrid, 2000;; igualmente hay que tener presente los trabajos de H. Casado, M.I. Val Valdivieso y J.M. Monsalvo.

4 «La nobleza en la Asturias del Antiguo Régimen», es un ambicioso proyecto en equipo, subvencionado por la Universidad de Oviedo, y del que este trabajo es su primer fruto. 
nos obliga al uso de diversas metodologías, procedentes tanto de la historia económica, como de la social y política. Métodos cuantitativos, análisis de redes sociales, estrategias familiares, vínculos clientelares, genealogías, etc. nos ayudan en una investigación cuya finalidad es, en definitiva, interdisciplinar y multifocal.

En cuanto a este trabajo, la documentación existente es abundante; procede básicamente de los actos administrativos y jurídicos llevados a cabo por la burocracia de los Austrias y se encuentra principalmente en el Archivo General de Simancas, aunque también se han utilizado documentos procedentes de los archivos municipales y de los nobiliarios 5 .

Nos interesa conocer la geografía y la cronología de las ventas, cargos vendidos y precio y demanda de los mismos, sociología de los compradores y trámites jurídicos seguidos para la compra y uso del cargo. En definitiva, queremos evaluar el monto económico de estas enajenaciones y sus consecuencias económicas y sociales, así como los cambios que van a introducir en el gobierno de los municipios. Intimamente relacionado con esta cuestión debemos analizar y sopesar la resistencia de la sociedad y de las instituciones asturianas a la puesta en práctica de este expediente.

\section{EL RÉGIMEN MUNICIPAL ANTERIOR A LAS VENTAS}

En primer lugar, es importante conocer cómo se gobernaban los concejos asturianos antes de 1544, fecha de comienzo de la venta de oficios, ya que es un referente básico para evaluar los cambios habidos posteriormente. Los oficios tenían un carácter electivo y anual, aunque la nobleza tenía una mayor participación en el gobierno.

Sabemos por algunos estudios de la existencia de bandos a comienzos de la Edad Moderna y las tensiones que había en torno a las elecciones ${ }^{6}$. No tenemos datos suficientes para evaluar el control que tenían los caballeros asturianos sobre los gobiernos municipales; sería importante poder precisar el grado de acaparamiento del poder en los diversos concejos, que sin duda era grande, tal como ex-

\footnotetext{
5 Las secciones más consultadas de Simancas han sido Dirección General del Tesoro, Cámara de Castilla. Oficios y Consejo y Juntas de Hacienda, en especial los Libros Registro. En los archivos nobiliarios se han consultado datos sobre nuestro tema relativos a las casas de Argüelles, Queipo de Llano, el Archivo Revillagigedo (casa Ramírez, casa Omaña, casa Canalejas, casa Estrada-Nevares, Morteras, Grado, Inclán) y Marcenado (casas de La Rúa y Navia Osorio) y los archivos privados depositados en el Archivo Histórico Provincial de Asturias (Posada, Cutre, Labra y Sobrino), que aportan información sobre estas casas, así como sobre los Cebos, Intriago, Junco y Prieto, entre otros. Igualmente se han consultado archivos municipales, en especial el de Oviedo, así como las Actas de ia Junta General del Principado.

6 Así lo constata Cuartas Rivero, M.: Oviedo y el Principado de Asturias a fines de la Edad Media, Oviedo, 1983. Lo mismo sucede en el resto de España; respecto al País Vasco puede verse $\mathrm{R}$. PORRES, «Oligarquías y poder municipal en las villas vascas en tiempos de los Austrias, Revista de Historia Moderna. Anales de la Universidad de Alicante, 19. 2001, pp. 315-317.
}

Hispania, LXIII/1, núm. 213 (2003) 75-136 
presan diversas órdenes emanadas de los Reyes Católicos en $1493^{7}$. Las ordenanzas de Hernando de Vega de 1494, al introducir el sistema de suertes, debieron dificultar el control de cargos por la capa alta de la nobleza y traer, al mismo tiempo, una disminución de la conflictividad. No obstante, $M$. Cuartas opina que con el sistema insaculatorio hubo un amaño de las elecciones a favor de algunas familias que tenían derechos consuetudinarios en los concejos de Villaviciosa, Nava, Carreño y Candamo (los Balbín, los Nava, los Carreño y los Miranda).

En Oviedo, los ocho regimientos que existían se nombraban cada año por los regidores del año anterior. En 1520 Alonso de Huergo acusa que

«de ciertos años a esta parte algunas personas principales del concejo de Oviedo traían entre sí los juzgados con formas y maneras que tenían, gozando dello y dándolos a deudos y criados y a personas inhábiles, los cuales diz que vendían los dichos oficios a vecinos del concejo y procuraban que viviesen con ellos y los sirviesen y acompañasen tomándoles sobre ello juramento que al tiempo que salieren elijan e nombren a quienes ellos quisieren»8.

Por su parte, en Grado los linajes nobles (los Gremios) habían llegado a un acuerdo para acaparar los cargos municipales, alternándose pacíficamente en el poder desde 1450 , costumbre que lograron mantener a lo largo del tiempo. En 1562 con el fin de que la Corona les vendiera un regimiento perpetuo aducen prevalencia en las elecciones anuales de los concejos donde tenían solar Juan de Carrio (Carreño), Alonso de Inclán (Pravia), Fernán Alvarez de Grado (alfoz de Candamo), Alonso de Carreño (Avilés) y Pedro de Valdés de Manzaneda $\left(\right.$ Gozón) ${ }^{10}$.

\footnotetext{
7 En una de ellas se manda que los procuradores de la Junta los elijan libremente los pueblos y no los caballeros y escuderos, que «atemorizando y amenazando para que se haga en la Junta lo que ellos quieran ... van con gentes que les acompañan y muchas veces resulta escandalos y riñas». Igualmente, otra provisión del mismo año ordena que los caballeros y personas principales de Asturias no se entrometan en los juzgados y oficios, dejando a los pueblos ponerlos libremente. Archivo Ayuntamiento de Oviedo, Libro de Pragmáticas, t. I, fols. 1, 8 v. y 10. No hay en la Asturias del siglo XVI otros grupos sociales con fuerza para luchar por el poder, como parece que existió en muchas de las ciudades castellanas y andaluzas, especialmente las que tenían una economía más floreciente, tal como reflejan los estudios de B. González Alonso, A. Marcos Martín y M.I. Val Valdivieso entre otros.

8 CuARTAS, M.: op. cit., p. 263. Avala la escasa participación existente en las elecciones y la tensión que ello debió producir el que en 1584 la justicia y regimiento de la ciudad diga a S.M. que se sienten agraviados de la solicitud que le hicieron los vecinos de Oviedo contra la costumbre y prerrogativa que la corporación tenía de entrar en la elección de alcaldes y alguaciles mayores de las jurisdicciones de la ciudad conjuntamente con los demás vecinos y solicita no se perjudique sus derechos. A.M.O., C-10.

9 Fernández De Miranda, A.:, Grado y su concejo. Grado, 1982, p. 160 y ss.

10 A.G.S., C.J.H., lgs. 53, fols. $12-13$ y 14; lg. 46, fol. 198; lg. 54, fol. 203; lg. 20, fol 77 y lg. 41 , fol. 75 bis. Pedro de Valdés dice que la casa de Manzaneda nombraba desde tiempo inmemorial la mitad de los oficios de Gozón (la tierra de Manzaneda) y que al crear el alferazgo en la otra
} 
Sucedía en Oviedo, tal como dice Gonzalo de Argüelles en 1543, año de comienzo de la venta de regimientos, que

«en la dicha ciudad siempre ha abido y al presente hay dos parcialidades y linajes, el uno de la casa de Arguelles y el otro de la casa de la Rua y entre ellos siempre se han partido los dichos regimientos».

Sabemos por diversas informaciones que, al menos en algunos concejos, aún existían «parcialidades» en la segunda mitad del siglo XVI y que el propio Felipe II procuró vender los regimientos, tanto en los años sesenta como en los ochenta, haciendo un reparto entre los diversos bandos existentes. La propuesta del corregidor al Consejo de Hacienda en 1561 sobre las personas más convenientes en quienes perpetuar los regimientos busca un equilibrio entre las diversas «parentelas» 0 «linajes» ${ }^{11}$; algunos excluidos de la lista, con los mismos argumentos, aducen agravio para su bando y la necesidad, para que hubiera "paz y sosiego" en el gobierno, de un reparto equitativo de las regidurías ${ }^{12}$. Por estas informaciones sabemos que se producía esta situación en Lena, Sariego, Corvera, Carreño y Siero ${ }^{13}$.

También en 1581 el corregidor hace referencia a la existencia de «parcialidades» en Siero, en Cangas de Tineo y en Gozón y considera que deben venderse regimientos a todas ellas. Así pide que en Cangas se den por mitad a Arias de Omaña y a Diego García de Tineo y respecto a Gozón dice que había rivalidad entre el linaje de los Pola y el de los Valdés, que éstos últimos son "gente principal» y están agraviados porque sólo tienen uno o dos oficios y deberían dárseles más porque "parece estaria mejor gobernado»"

Además como dice Alonso de Guergo en 1561 «las personas prencipales controlan el nombramiento de oficios y ... son rexidores por fulano y fulano

\footnotetext{
mitad del concejo (La Pola de Luanco) ya no había igualdad entre las dos mitades del concejo en cuanto a número de regidores; pide que para que no se rompa esa igualdad se acreciente un regidor en Manzaneda y se le conceda a él.

11 A.G.S., C.J.H., lg. 41, fols. 72 y 74.

${ }_{12}$ Gutierre de Hevia cree deben dividirse los regimientos a perpetuar entre las parcialidades de los concejos «porque si los lleva una seria mayores pendencias».

13 Aducen ser cabezas de bando y que cesarán los escándalos si se les nombra Alonso Fernández de Riba en Sariego y Pedro de Solís en Corvera. Juan de Carrio, con solar en Carreño, dice que «biene en disminucion la dicha casa y sus deudos y parientes»; por su parte, Gutierre de Hevia, el mayorazgo, pide ser nombrado regidor de Siero y aduce que hay tres linajes principales en el concejo, los Vigil, los Argüelles y los Hevia y que, al no ser propuesto, resulta «agraviado el y sus deudos y parientes». C.J.H., lgs. 44, fol. 32; 51, fols. 103 y 122 y 53, fols. 12 y 13 . Igualmente un argumento aducido para pedir el acrecentamiento de escribanías es que debería haber dos, al menos, en cada concejo "por las parcialidades que en ellos hay». C.J.H., lg. 130, fol. 3.

14 Informe mandado en 1581 al Consejo de Hacienda por el doctor Pernia, corregidor del Principado, pedido por Felipe II para llevar a cabo el fuerte acrecentamiento de oficios en los años siguientes. A.G.S., D.G.T., lg. 321, fols. 9 y 24.
}

Hispania, LXIII/1, núm. 213 (2003) 75-136 
tiene tantos rexidores» ${ }^{15}$. Pero a pesar de la redes de clientelismo que existían, no cabe duda que el gobierno de la nobleza se veía obstaculizado por diversos motivos - muy en especial, el procedimiento insaculatorio-y que los intereses del resto de los grupos sociales estaban más o menos representados. Aunque sin duda existía la compra de los votos y fraude en las elecciones, no obstante, como dice en 1561 un testigo de la información del corregidor «son mejores los regimientos cadaneros que los perpetuos porque caerian en personas prencipales y la tierra es pobre y vendria daño a los vezinos pobres» ${ }^{16}$. Prueba de esta participación popular es la frecuente referencia a la baja extracción social y falta de cultura de muchos regidores a lo que aluden con malestar y desprecio muchos miembros de las élites; donde hay cadaneros, dice Pedro Menéndez de Oviedo, «son personas baxas e personas rusticas por la mayor parte». Con el fin de argumentar un mejor gobierno a través de regimientos perpetuos, algunos miembros de las clases superiores aluden a la facilidad con que estas personas son atemorizadas e, incluso, compradas por los ricos y poderosos, así como al poco tiempo que pueden dedicar al ejercicio de su cargo: «haçen las eleçiones por dadivas e por miedo ... y por no saber leer los rregidores syenpre ay fraude en las heleçiones». La disminución de la participación popular en el gobierno municipal de los concejos de realengo, se acentúa a partir del comienzo de la patrimonialización de los cargos en los años cuarenta, como enseguida veremos.

El control del gobierno municipal por unos pocos era, sin duda, menor en los concejos redimidos, antiguas jurisdicciones eclesiásticas vendidas por Felipe II en los años ochenta. Su estatuto de exención les va a preservar un tanto de la oligarquización que se estaba produciendo en los concejos de realengo; si antes de la redención la presencia de un señor dificultó la toma de importantes cuotas de poder por la nobleza, posteriormente van a verse libres de la venta y perpetuación de cargos. A pesar de las fuertes tensiones sociales existentes en el momento del cambio de estatuto jurídico de lugar de señorío a concejo exento, debido sobre todo al control del poder que intentaron las principales familias, la realización de ordenanzas para regirse va a traer una mayor participación social en el gobierno municipal. Aunque algunos intentaron que el rey les vendieran cargos no lo van a conseguir ${ }^{17}$.

\footnotetext{
15 A.G.S., C.J.H., lg. 41, fol. 72.

16 A.G.S., C.J.H., lg. 41, fol. 72.

17 Algunos particulares intentaron que el rey les vendiera un cargo. Así, Hernán Montes Vigil, Alonso García Riaño y Gutierre García Riaño, vecinos de Langreo, solicitan un oficio de regidor ante el Consejo de Hacienda, argumentando que «a caussa de que la mayor parte del concexo es gente comun y de poca hacienda en cada un año en la elecion de los oficios de justicia y administracion della ay muchos alborotos y escandalos». Proponen además que con el dinero de éstas y otras ventas se podría pagar parte del dinero que costó el rescate del concejo y se ofrecen a nombrar "personas prenzipales aviles y suficientes y en quien concurren las calidades necesarias para los dichos oficios». Sobre el gobierno de los concejos redimidos puede verse con más amplitud FAYA DíAZ, $\mathbf{M}^{\mathrm{a}}$
} 
Un buen indicador de las dificultades que tiene la nobleza para monopolizar los oficios en los concejos exentos lo expresa ante la Junta General del Principado el diputado por el concejo de Langreo (Gabriel Argüelles, de la casa de su nombre); opina en 1622 (momento en que se estaban elaborando unas nuevas Ordenanzas para el Principado) que no le gustaba cómo se hacían las elecciones en los concejos redimidos, ya que se daban los oficios a "personas pobres de poco aver y poco suficientes y desavonados para el uso dellos, de que se siguia daño"; sin embargo, el representante de Teverga diçe que en su concejo se eligen los oficios "por botos de la mayor parte y que asta aquí no se an allado mal con ellos». A pesar de que se debatió en dicha Junta si en los concejos redimidos la elección debía ser por concordia de todos los vecinos o por suertes se acordó esta última opción en contra de lo que opinaba el citado Pedro Argüe$1 l e s^{18}$. Efectivamente el sistema que va a prevalecer es una combinación de insaculación y representatividad indirecta a través de electores elegidos en concejo abierto por todos los vecinos.

\section{OFICIOS VENDIDOS, PROCEDIMIENTOS Y TRÁMITES SEGUIDOS}

Los Reyes Católicos habían abolido por el Ordenamiento de 1480 la perpetuidad de oficios disponiendo además el consumo de los acrecentados desde 1440. Va a ser a partir de 1543 cuando se comienzan a vender oficios de modo continuado como una forma de conseguir dinero. Pero la enajenación de cargos públicos no estuvo regulada legalmente ni en su faceta pública (venta de la Corona a particulares), ni en su faceta privada (transmisión entre particulares). Por esta razón las ventas revisten formas ficticias, toman la forma de donativo (a veces justificado en los títulos concedidos por necesidades financieras y militares), mientras las transmisiones entre particulares adquieren la de renuncia ${ }^{19}$. Esta es una de las razones de los problemas para investigar el tema; Tomás y Valiente considera que hay dificultad para cuantificar y hacer una síntesis general, que he podido constatar ${ }^{20}$.

A.: Los señoríos eclesiásticos en la Asturias del siglo XVI, op. cit., pp. 341-361. Igualmente, en 1594 Min de Miranda quiere que se vendan en el concejo de Quirós seis regimientos y un alferazgo y pide información del corregidor sobre su conveniencia, pero Gutierre Bernaldo, mayorazgo de la casa de Quirós, contradijo por sí y otros vecinos esta solicitud.

${ }_{18}$ Actas ... op. cit., t. II, pp. 270-271 (sesión de 3-11-1622).

${ }_{19}$ La renuncia debía ser aprobada por la Corona; estaba sometida a unos plazos estrictos para evitar el tráfico de oficios, debiendo realizarse, al menos veinte días antes de morir. No obstante, por causa de muerte o por otras muchas (ausencia, posesión de varios cargos, propiedad de mujer viuda o soltera o de un menor de veinticinco años, incompatibilidad con su profesión) el sistema va a ser muy utilizado.

${ }^{20}$ Gobierno e instituciones ..., op. cit., p. 155. Mi interés de disponer de todos los datos para poder cuantificar el tema y, en definitiva, para llevar a cabo un análisis exhaustivo, se ha visto frustrado en alguna medida. A pesar del importante número de legajos consultados en diversas secciones de

Hispania, LXIII/1, núm. 213 (2003) 75-136 
Se vendieron en Asturias oficios de carácter muy diverso, algunos ya existentes, otros de nueva creación. Hay que distinguir, por un lado, los de carácter general con competencias en el conjunto del Principado (alférez mayor, merino mayor, depositario de las rentas reales, tesorero de las rentas reales, procuradores de número) y, por otro, los cargos propiamente municipales. Entre éstos últimos hay que diferenciar, en primer lugar, aquellos que tienen voz y voto en los ayuntamientos (oficios de poder les llama Tomás y Valiente), tales como reximientos, alferazgos, alguacilazgos y alcaidías de cárcel. En segundo lugar, están las escribanías (número, puridad, millones, diezma de la mar) y las procuradorías de número. En tercer lugar, están aquéllos oficios con competencias directamente económicas, tales como depositarías generales de los concejos $^{21}$, tesorerías de rentas reales y receptorías de penas de cámara, contaduría de millones, fieldades y corredurías.

Algunos de estos oficios eran de nueva creación, otros antiguos y de provisión de la Junta del Principado, de la ciudad de Oviedo o de los gobiernos locales. En ambos casos, las instituciones afectadas sienten vulnerados sus derechos y consideran que no se respecta la legalidad. Aunque la Corona recurre a la venta de cargos como un recurso financiero más, va a justificar este tráfico de oficios con distintos argumentos y no sólo como una forma de arbitrar dinero para los gastos militares derivados de su política exterior.

Se suele aducir a menudo no tanto motivos financieros, como razones de paz social, de buena gobernación y de eficacia en el ejercicio del cargo. Ya las primeras ventas en Asturias las justifica la Corona diciendo que ha sido informada

«de los daños y inconvenientes y diferencias que se siguen en algunos pueblos destos reinos y señorios de la corona de Castilla donde los oficios de regimiento heran cadañeros y añales especialmente al tiempo de las eleçiones de los dichos oficios y que de los dichos yncovinientes cessaria haziendolos perpetuos como los ay en otros pueblos de los dichos reinos».

No obstante, puntualiza que su voluntad es que, si se aumenta el primitivo número de regidores, éstos deben de consumirse a la muerte de sus propietarios.

Felipe II inicia a comienzos de su reinado las primeras perpetuaciones «por juro de heredad», así como el acrecentamiento del número primitivo de regimientos y escribanías de los concejos. Tanto en 1558 al crear los alferazgos en muchos concejos, como en 1560 en que perpetua los regimientos en los mismos, utiliza argumentos de buena gobernación y de paz social; dice que

\footnotetext{
Simancas y del cotejo con informaciones de otros archivos han quedado lagunas y puntos oscuros que limitan el objetivo inicial.

21 Vendidas con voz y voto en el ayuntamiento, en realidad venían a ser una regiduría más; aunque enajenadas en principio por dos vidas, en 1614 y años siguientes se les dio la posibilidad de perpetuación.
}

Hispania, LXIII/1, núm. 213 (2003) 75-136 
«quiere que los pueblos dese Prenzipado sean bien gobernados que donde los reximientos son anales se criasen e hiziesen perpetuos... para que con ygualdad e sin parzialidad ni pasion sean rexidores y gobernados los dichos pueblos».

También justifica su decisión en que así lo desea el Principado; notifica al corregidor que éste se lo pidió «para evitar muchos desasosiegos parzialidades y otros ynconbinientes que podian resultar» y le encarga que indague las personas que fueren más convenientes para proveer dichos cargos ${ }^{22}$. Tampoco hay cambio de argumentos en los acrecentamientos de los años ochenta y no es frecuente que se aduzcan necesidades financieras. En 1583 la Corona informa al corregidor que son hechos

«por escusar los daños e ynconvenientes que sobre las eleçiones de los dhos. officios an sucedido y cada dia subceden» y que quiere «el buen gobierno y quietud de los dhos. concejos que no aya en ellos divisiones ni parcialidades» ${ }^{23}$.

En los títulos de procuradores de causas que el rey vende a comienzos de los años setenta se utilizan argumentos de profesionalidad y eficacia; dice que

«Conviene y es necesario que aya numero dellos para que los negocios que se ofrecieren a los vs. y forasteros de la dha. ciudad se puedan seguir con mas comodidad de las partes y que ellos y no otros den las peticiones y agan los autos ante cualquier juezes y justicias della como lo hacen los otros procuradores que ay en las demas ciudades y villas y lugares destos Reynos».

Igualmente al vender la alcaidía de la cárcel de Oviedo en 1581 se justifica la enajenación de este cargo diciendo que en la guarda de los presos no hubo «ni ay la buena custodia y recaudo que convernia» ${ }^{24}$.

Las depositarías de los concejos van a ser justificadas del mismo modo en 1617:

«Por quanto por esperiencia se an visto los ynconbimientes y escandalos que an sucedido y suceden cada dia a causa de proveerse y nombrarse personas por no ser conocidos ni abonados ni dar las fianzas necesarias para seguridad de los dichos depositos para remedio de lo qual y por otras algunas justas causas abemos acordado nombrar personas que sean aviles y suficientes y abonadas en cuyo poder se pongan los depositos en lugar de los que asta aquí lo an echo» 25 .

${ }^{22}$ A.G.S., C.J.H., lg. 41, fol. 72. En los títulos de perpetuación se insiste en que se trata de que haya «mas quietud sosiego y paz e no aya pasiones». Título de regimiento a Urbano de Huergo de 20-12-1562. A.U.O., Casa de Argüelles, caja 47. Igualmente se justifica la perpetuación de los regimientos del concejo de Illas en 1569 diciendo que «suele aber sobre la eleçion dellos muchos ruydos y escandalos que para lo remediar convernia que los dhos. offiçios se perpetuasen como en las otras villas y concejos de dho. Principado». A.G.S., C.J.H., lg. 91, fol. 229.

23 A.G.S., C.C., Oficios, lg. 3

24 A.G.S., C.J.H., Registros, lib. 353.

25 A.G.S., C.J.H., lg. 548, fol. 2.

Hispania, LXIII/1, núm. 213 (2003) 75-136 
El fuerte acrecentamiento de oficios que tuvo lugar en los años treinta del siglo XVII se justifica tanto en el permiso concedido por el Reino como en los agobios militares derivados de la política exterior en esos años. En los títulos concedidos a fines de los años treinta se justifica como donativo

«para suplir parte de los grandes e inescusables gastos que tengo en defensa de mi monarchia y de mi sagrada religion por aberse coligado tantos contra ello sustentando yo por esta causa gruesos exercitos y armadas».

En la enajenación de oficios se van a seguir varios procedimientos para obtener dinero ${ }^{26}$. En las primeras etapas de las ventas, se venden cargos que eran anuales (estuvieran o no vacantes) generalmente por la vida del comprador. Pero pronto se van a acrecentar el número antiguo de los existentes, al mismo tiempo que se crean nuevos oficios y, en ambos casos, con carácter de renunciables. La Corona daba, previo pago, las licencias de renuncia para que el propietario de un cargo pudiera pasarlo a otra persona. Finalmente, a los cargos vitalicios se les va a conceder la perpetuidad a cambio de dinero, con lo que van a pasar a patrimonio de sus propietarios, que los pueden vincular y transmitir al igual que el resto de sus bienes ${ }^{27}$. Aunque nos constan algunas perpetuaciones «por juro de heredad» a fines de los años cincuenta del siglo XVI, será en 1614 y años siguientes cuando se van a perpetuar la mayoría de los cargos renunciables anteriores, imponiéndose además en las nuevas ventas esta característica.

Era el Consejo de Hacienda quien tomaba la iniciativa sobre las ventas a realizar y el encargado de todos los trámites. En primer lugar, pedía informes a los corregidores sobre posibles oficios a enajenar, precios y personas a quienes se podían vender.$^{28}$ El Consejo de Hacienda se informaba de los cargos que ya iban vendidos en un municipio y los precios de los mismos y, tras consulta de los Libros de la Razón, decidía nuevas ventas y fijaba los precios, aprobando o no los solicitados por algunos particulares. El procedimiento facilitaba la especulación y el favoritismo ${ }^{29}$.

La forma de pago podía ser al contado, aunque también se aceptaba el pago aplazado (en dos o tres plazos a lo largo de un año o año y medio), previa carta de obligación del comprador. El tesorero general era quien normalmente

${ }^{26}$ A veces es un factor quien adelanta a la Hacienda dinero, o bien ésta salda con él sus deudas autorizándole a vender oficios en cantidad equivalente a dicha deuda.

27 A partir de 1631 la media annata es una carga que afecta también a los oficios (generalmente un $2,5 \%$ del valor del cargo); todo nuevo propietario, sea por compra sea por herencia, debía satisfacerla a Hacienda.

${ }^{28}$ Para Asturias es especialmente importante el enviado por el Dr. Pernia en 1581, aunque hubo otros anteriores. Así en 1543, 1544, 1547, 1557, 1561 y 1566; igualmente va a ser decisivo, como luego veremos, el enviado por Pedro López de Mesa en 1561. En los años ochenta hubo también otros informes y en el siglo XVII nos consta el realizado en 1630.

${ }^{29}$ Los que vivían en la Corte compraban y luego revendían oficios; otras veces, dada su información privilegiada, compraban cargos para sus parientes o amigos. 
recibía el dinero recaudado de la venta de oficios, pero a veces era un factor quien se encargaba de vender y cobrar; a veces el dinero iba directamente a la cuenta de un asentista de la Corona. Muchos pagos de compras de oficios no aparecen registrados por éste u otros motivos. Finalmente el Consejo de Hacienda expedía el título, aunque debía ser firmado por el rey y refrendado por la Cámara de Castilla.

Ante estas operaciones de venta muchos concejos negocian con la Corona para que no se acrecienten oficios ni se creen otros nuevos y piden su supresión o que sea el concejo quien los pueda proveer, bien pagando a la Corona, bien al comprador la cantidad que ya había satisfecho. A menudo, sobre todo la Junta del Principado y la ciudad de Oviedo se aventuran en pleitos, como luego veremos, especialmente respecto a los cargos considerados más perjudiciales; otras, aunque menos, se intenta el consumo de todos los cargos.

El malestar de los pueblos también va a permitir a la Corona sacar dinero a través de la composición entre ambas partes. Ante las quejas de las Cortes de 1570 que pedían derogase la obligación de pleitear por medio de los procuradores que Felipe II había creado en las ciudades, éste accede al consumo a cambio de que dieran a los compradores el dinero que habían pagado por estos cargos. Como dice Domínguez Ortiz éste es «el primer paso en una larga serie de chantajes contra las haciendas municipales» ${ }^{30}$. Podían pedir el tanteo, comprometiéndose la Corona a no volver a vender el oficio resumido, aunque también es cierto que no siempre respetó esta promesa.

A comienzos de los reinados de Felipe III y Felipe IV se dieron leyes de reducción de oficios de carácter general, que expresan la buena intención inicial de ambos reyes y sus deseos de reforma. Así la pragmática de 21-1-1602 permite consumir regimientos, juradurías y escribanías en lugares de menos de 500 vecinos, que hubieran sido creados o acrecentados a partir de 1540, la de 1609 faculta para consumir depositarías, tesorerías de alcabalas y otros semejantes y las de 10-2-1623 y 29-1-1638 también mandan reducir oficios concejiles. El 29-5-1669 Mariana de Austria decreta la extinción de los oficios vendidos con posterioridad a 1630 y que tuvieran voz y voto en los ayuntamientos, así como que no se vendan más en adelante; se justifica

"por la opresion que padecen los pueblos debajo del gobierno perpetuo de los mas poderosos, recayendo la mayor carga en los pobres, de que nace despoblarse los lugares y el descaecimiento de las rentas reales».

Pero esta pragmática exceptúa del consumo los cargos de las ciudades con voto en Cortes y de las cabezas de partidos. Sabemos que, en base a esta ley, se trataron de resumir en Asturias oficios de regimiento; en la sesión de 25-11672 de la Junta General del Principado se pide que la Corte concrete cómo

30 Domínguez Ortiz, A.: «La venta de cargos...», art. cit., p. 112.

Hispania, LXIII/1, núm. 213 (2003) 75-136 
satisfacer a los dueños el coste que tuvieron con su compra, así como los medios que debían arbitrarse para que los concejos pudieran pagarles. Domínguez Ortiz considera que, en general, apenas debió aplicarse esta cédula por confabulación de los corregidores con los interesados ${ }^{31}$.

\section{Cronología y geOgRAFía de LAS VENTAS}

En los concejos y cotos de titularidad señorial y en los concejos exentos no van a producirse ventas, salvo algunas escribanías en algunos de éstos últi$\operatorname{mos}^{32}$. Las enajenaciones van a realizarse en los concejos de realengo de la corona castellana, comenzando por las ciudades y villas más importantes (ver MAPA 1). Hay una estrecha relación entre el incremento de las ventas y el de las necesidades del Estado y, en definitiva, con la política exterior de los Austrias ${ }^{33}$.

La acumulación de deudas en los últimos años del reinado de Carlos V, unido a la continuación de las campañas militares, le lleva a recurrir a diversos arbitrios, entre ellos la venta de oficios ${ }^{34}$. Comienza la enajenación de modo titubeante ${ }^{35} \mathrm{y}$, en el caso de Asturias, se va a centrar en los oficios de regimientos y escribanías. Aunque ya en 1543 se venden muchos oficios en Castilla y en Andalucía, en Asturias empiezan en 1544. En este año empiezan las ventas de los regimientos de algunos de los concejos más importantes (Oviedo, Avilés, Gijón, Villaviciosa, Colunga, Pravia y Gozón); en los años siguientes, especialmente en 1549, hay acrecentamientos en estos mismos municipiòs (se crean dos nuevos regimientos en Oviedo, Gijón, Avilés y Villaviciosa) ${ }^{36}$.

31 Domínguez Ortiz, A.: «La venta de cargos...», art. cit., pp. 124-125.

32 Así sucede en Navia (1567), Pronga (1587), Sobrescobio (tanteada tras compra de Diego de Solís en 1592 y perpetuada en 1619), Castropol, Langreo y Ribera de Arriba (escribanía de millones, 1635 y 1636 ).

33 Puede seguirse la cronología de las ventas de modo pormenorizado en los CUADROS 2 y 3. La extensión de esta publicación nos impide poder ofrecer la información sobre la venta de escribanías, aunque se ha utilizado en el análisis global realizado.

${ }^{34}$ En 1544 había un déficit de 414.500 ducados y para saldar las deudas se pensó -entre otros arbitrios- en la venta de oficios; se consideró en Hacienda que «de las facultades para rrenunciar los oficios lo que pareçe la cosa mas sin perjuycio del rreyno de todas las que se puedan ofreçer porque solamente se quita a su magestad la provision de los ofiçios por una vez en lugar de esto se acrecienta por otra parte la provision de todos los ofiçios que eran cadañeros y se hazen perpectuos». A.G.S., C.J.H., lg. 17, fol. 1-3.

${ }^{35}$ En realidad, ya en 1523 hubo un intento de ventas, tal como denunciaron las Cortes de ese año.

36 Según las cuentas del tesorero Alonso de Baeza se recauda por este arbitrio en el conjunto de la corona de Castilla 195.600 ducados en $1543,151.828$ en 1544 y posteriormente va bajando el monto de las ventas hasta fines de su reinado, salvo en 1549 en que sube a 123.246 ducados. Pero se utilizan también otros arbitrios, especialmente en los años cincuenta; así en 1553 ascienden a un total de 150.724 ducados (villazgos a aldeas que se separan de su cabecera 110.300 ducados, venta de jurisdicciones de monasterios 12.000 ducados, venta de hidalguías 5.000 ducados, venta de oficios 2.570 ducados); además en juros se allegan 20.854 ducados. A.G.S., D.G.T., lg. 490, C.C. Relación, lib. 7 y C.J.H., lg. 38, fol. 153. Entre 1543 y 1556 se vendieron regimientos de lugares de las Ordenes Militares por un valor de 134.158 ducados. A.G.S., C.C., lg. 23.

Hispania, LXIII/1, núm. 213 (2003) 75-136 


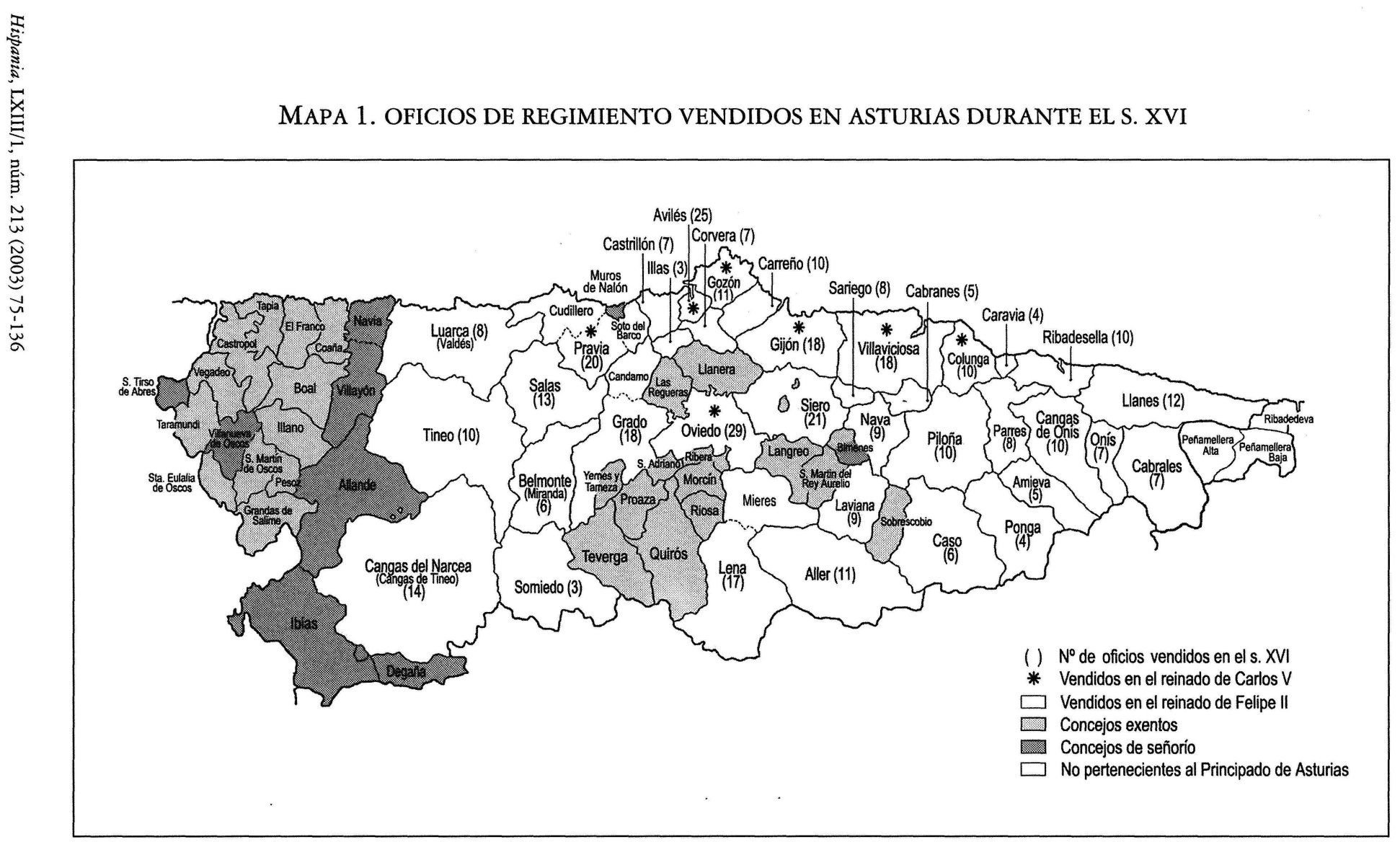


A partir del comienzo del reinado de Felipe II la venalidad de oficios cobra nuevo impulso. Se van a vender en 1557 y 1558 cargos en el conjunto de la corona castellana por un valor de 324.808 ducados en 1557 y de 187.837 ducados en $1558^{37}$. En Asturias, se enajenan regimientos y escribanías en los concejos antes citados y, además, se crean los alferazgos, que se van a vender en 24 concejos $^{38}$.

El cuarto acrecentamiento de oficios tiene lugar de 1562 a 1568, fechas en que se venden nuevamente un número importante de cargos en Asturias, tanto regimientos como escribanías, y se crean procuradurías, así como la receptoría general de las rentas reales del Principado ${ }^{39}$ y las depositarías generales de Oviedo y de otros trece concejos ${ }^{40}$. Tras información pedida a fines de 1560 al corregidor Pero López de Mesa sobre el número antiguo de regimientos de los concejos donde se habían creado alferazgos y sobre precios y personas a quienes se les podían vender, se inicia en 1562 una importante operación de perpetua-

37 En 1557 se venden regimientos, veinticuatrías y escribanías (276.989 ducados), así como procuradurías y escribanías en las Chancillerías ( 47.819 ducados). En este año también se recurre a otros arbitrios que suben a 223.997 ducados (venta de jurisdicciones 204.301 ducados e hidalguías 12.176 ducados y juros 7.520 ducados). En 1558 se enajenan los mismos oficios, además de tenencias y alcaidías de fortaleza y oficios de las Chancillerías (éstos suben a 6.888 ducados). Otros arbitrios usados son venta de jurisdicciones y de términos eximidos (187.837 ducados) e hidalguías (9.000 ducados); además se ingresó por sede vacante y expolio del arzobispado de Toledo 68.722 ducados. A.G.S., D.G.T., lg. 491, 1299, 815 y 1458 y C.J.H., lg. 35, fols. 224-226 y 231 bis.

${ }_{38}$ Sabemos que, al menos algunos regimientos, fueron vendidos perpetuamente por juro de heredad con facultad de ser incluidos en el mayorazgo y trasmitidos por herencia. Por otro lado, el alférez era responsable del mando militar en el concejo, así como debía alzar el pendón de la villa y tener en su poder tambores, banderas, pendones y otras insignias; además se le concede la misma calidad que a los regidores, pero lugar preferente sobre ellos en el ayuntamiento. Hay que destacar, desde la creación de este oficio -y también posteriormente-- el frecuente cambio de titularidad, así como pleitos sobre la misma. Así el alferazgo de Gozón, comprado por Rui González de la Pola, fue renunciado en Benito Carreño, pasando luego a Pedro de Prendes y, tras venta judicial por deudas de éste, recayó en 1611 en Lucas Peláez Pola. En 1633 Juan de Granda Prendes aduce ser suyo y pleitea con la viuda de Lucas Peláez Pola. A.G.S., C. C., lg. 2139. Igualmente el alferazgo de Gijón fue motivo de litigio entre la casa Jovellanos y la de los Ramírez. A. G. H., Archivo Revillagigedo, casa Ramírez, ms. 302, L. $13, \mathrm{n}^{\circ} 7$ y 8.

39 Asciende su venta a 2.035 ducados; se incluye en el cargo la tesorería de alcabalas y tercias y otras rentas ordinarias y la receptoría de penas de cámara. Se vende a Juan de Robles, regidor del concejo de Aller, por dos vidas y salario de 96 ducados anuales, además de 10.000 al millar por lo que recaudare cada año por las penas de cámara. Éste lo va a traspasar a Juan de Carrio Valdés y por fallecimiento pasa, finalmente, a Fernando de Valdés Bernardo, ambos regidores de Oviedo. Debido a sus deudas, el juez de comisión Esquivel Dávila lo remató en 1593 en Gabriel Valenciano en precio de 1.000 ducados, cediéndoselo por los días de vida del último poseedor del oficio. A.G.S., C.J.H. Registros, lib. 359.

10 Sobre estos años puede verse A.G.S., D.G.T., Igs. 492, 493 , 494 y 321. Los concejos donde se venden depositarías son los de Avilés, Carreño, Gijón, Ribadesella, Villaviciosa, Cangas de Onís, Lena, Onís, Pravia, Siero, Corvera, Gozón y Sariego. Se venden por dos vidas y con voz y voto en el ayuntamiento -al igual que los regidores- y en los cinco primeros concejos citados se incluye en el cargo la receptoría de penas de cámara. 
ción de regimientos, que afecta a muchos concejos del centro y oriente de Asturias (Aller, Laviana, Lena, Parres, Piloña, Cabranes, Sariego, Siero, Cangas de Onís, Onís, Ribadesella, Caravia, Carreño, Castrillón y Corvera ${ }^{41}$. El objetivo de la Corona era sacar de estas perpetuaciones seis mil ducados ${ }^{42}$. Durante los años setenta las ventas de regimientos y escribanías se reducen de modo importante, especialmente desde 1574; las fieldades creadas en Oviedo y Carreño, así como las procuradurías de número de Oviedo fueron pronto tanteadas por la ciudad y el Principado ${ }^{43}$.

También a comienzos de los ochenta hay operaciones de venta en gran escala que siguen durante toda la década ${ }^{44}$, lo que origina enérgicas protestas de muchas ciudades castellanas y andaluzas, incluida Oviedo. Basándose en la información pedida al corregidor del Principado y que envió a Madrid en 1581, Felipe II comisiona a D. Alonso de Acuña en 1583 para vender oficios en Asturias. El Consejo de Hacienda había decidido el 5 de mayo de 1582 los cargos a vender en los distintos concejos, que llegan a un total de 116 regidurías, 57 escribanías, 8 alferazgos y 14 depositarías generales ${ }^{45}$. Es ahora cuando se comienzan a enajenar los regimientos de los concejos de Cangas de Tineo, Tineo, Valdés, Salas, Miranda, Nava, Cabrales, Amieva, Ponga, Caso y Llanes ${ }^{46}$.

Se perpetúan y acrecientan cargos y además se crean las escribanías de la diezma de la mar y se vende la alcaidía de la cárcel de Oviedo ${ }^{47}$. Entre 1583 y 1584 - periodo álgido de las ventas en Asturias - se vendieron 86 regimientos y 44 escribanías y entre 1585 y 1588 se perpetuaron 46 regidurías y 55 escribanías.

${ }^{41}$ A.G.S., C.J.H., lg. 41, fol. 72.

$42 \mathrm{El}$ rey informa al corregidor en junio de 1563 de que se han despachado los títulos de los oficios a las personas nombradas por él y que los envía a Asturias para evitar costas a los compradores; le pide que nombre persona que recaude el dinero, el cual sube a un total de 6.619 ducados, y lo lleve a la Corte. Le informa también que ha acrecentado dos regimientos en Siero y Corvera para Hernando de Somonte y Juan Bernaldo de Quirós, personas a su servicio en la Corte. A.G.S., C.J.H. Registros, lib. 351.

${ }_{43}$ Para los años setenta tenemos A.G.S., D.G.T., lg. 495 , 496, 497, 352 y 321 (fols. 2 y 5) y C.J.H., Registros, lib. 350 y 351.

44 Sobre las ventas en los años ochenta puede verse A.G.S., D.G.T., lgs. 321, 322, 499, 500 , 501 y 570; C.J.H. Registros, lib. 353, 355 y 357 y C.J.H., lg. 192, fol. 1.

45. A.G.S., C.J.H., lg. 192, 1, D.G.T., lg. 321, 9 y C.C., Oficios, lg. 3. A 2 de julio de 1583 ya llevaba vendidos oficios por valor de 2.771 ducados y el 26 de ese mes ya había sacado otros 1.700 ducados.

${ }^{46}$ Felipe II manda a Alonso de Acuña que tantee la posibilidad de enajenar oficios en este último concejo, pero que, de momento, se informe solamente, porque aduce que tiene la jurisdicción y oficios por privilegio de hace 300 años y porque le prometimos anteriormente - dice el rey- que no se los quitaríamos, ya que «es puerto de mar y frontera de enemigos y tierra muy esteril y que se guarda y defiende a su costa teniendo para este efecto atalaya de dia y de noche mucha gente que la velan y guardan». Finalmente, se van a vender regimientos en este concejo en 1587-1588. A.G.S., C.C. Oficios, lg. 3.

47 En 1581 se vende la alcaidía de la cárcel del Principado (donde iban los presos hechos en Asturias por el corregidor o su teniente) a Toribio de la Ribera en 1.500 ducados. A pesar de los intentos de enajenar también la alcaidía de la cárcel -donde iban los vecinos presos por la justicia ordinaria de la ciudad- no hubo comprador. Oviedo se resistió repetidamente a la venta de este cargo que llevaba incorporado el de merino de la ciudad. 
Donde primero y en mayor cantidad se perpetuaron y acrecentaron oficios a lo largo del siglo XVI fue en la ciudad y en algunas de las villas más importantes. Oviedo pasa de los ocho regimientos antiguos (vendidos de por vida en 1544 ) a 21 regimientos en 1581 y a 26 en 1600 . Del mismo modo, otros muchos concejos de la zona central de Asturias van a ver vendidos y aumentados de modo importante sus regimientos y escribanías. Durante el reinado de Felipe II con el incremento de las ventas se va a dar un paso definitivo hacia el dominio de la nobleza en los cabildos municipales.

Hubo municipios que se resistieron a la venta y perpetuación de sus oficios. Es el caso de Llanes ${ }^{48}$ y de Grado. En ambos concejos la Corona hizo varios intentos de perpetuación, —en Grado el último en $1591^{49}$ — pero pronto fueron resumidos los cargos vendidos. También Caravia redime los oficios en $1612^{50}$.

En la última década del reinado de Felipe II decreció en Asturias la venta de oficios municipales ${ }^{51}$ y a comienzos del de Felipe III algunas medidas a favor

${ }^{48}$ Llanes se va a oponer con fuerza a la privatización de sus oficios. F. CANELla dice que se redimieron los regimientos hacia 1600 , pero que el alferazgo sigue en manos de los Posada en el siglo XVII: Historia de Llanes y su concejo, México, 1996 (facs. de la edic. de 1896), pp. 166-167. También Llanes va a pleitear contra D. Fernando Duque de Estrada a quien Felipe IV concedió la alcaidía de la fortaleza de la villa en 1628; a pesar de la oposición se le perpetuó en 1636. D. Fernando adujo que había sido gozada por su casa durante muchos años tras donación del rey D. Enrique. A.G.S., C.C., $\lg .2139$.

${ }_{49} \mathrm{El}$ concejo antes de 1581 había resumido cinco regimientos perpetuos, pagando sesenta ducados por cada uno; igualmente había redimido en 300 ducados el alferazgo mayor, vendido por la Corona en 1557. En 1581 había cuatro regimientos anuales; diversos informes de los corregidores entre 1586 y 1588 dan su parecer sobre el número de regidurías que se podrían acrecentar, así como su reparto entre la villa y sus alfoces. Se trataba de tener en cuenta que la villa solo contaba con 50 vecinos y el resto 1.200. En 1591 la Corona, por comisión a Cristóbal de Quesada, vendió 18 regimientos por un precio de 9.000 ducados, despachándose los títulos ese mismo año. Pero los Gremios consiguieron, finalmente, que se anularan las ventas y siguiera gobernado el concejo por los linajes tradicionales como sucedía anteriormente. Las escribanías de este concejo se van a vender a partir de 1587. A.G.S., D.G.T., lg. 321, fol. 24.

so Este concejo pagó 1.347 ducados a la Corona en 1612. Del Llano, A.: El libro de Caravia, Oviedo, 1980, p. 92.

51 En estos años difíciles, la Corona sigue vendiendo oficios municipales en toda Castilla y su importe lo consigna directamente a los asentistas. Además, aunque disminuye la venalidad de oficios municipales, en gran parte por saturación, se enajenan muchos cargos de la administración central. A.G.S., C.J.H., Registros, lib.358, 359, 362, 373 y 374; también puede verse D.G.T., lgs. 506, 507 y 508. En Asturias también se intenta vender oficios, tarea que se encarga en 1588 al factor Fernando López de Campo y en 1590 a Antonio Guevara. En 1589 el corregidor D. Lope Zapata informa que se podrían vender escribanías de los registros de censos en 19 concejos asturianos, oscilando los precios propuestos entre los 400 ducados de la de Oviedo y 150 de la de Aller. A.G.S., D.G.T., lg. 321; igualmente en 1599 el rey pide al corregidor que informe en un plazo breve sobre la conveniencia de vender el oficio de guardamayor de ciudad o villa lo que, dice, «parece ser conveniente y poderse criar y instituir en las otras ciudades y lugares cercados deste Reino que hasta agora no le hay»; considera que si se le da a los compradores voz y voto en el ayuntamiento y se les perpetúa «avra muchos que huelguen de entrar en el». A.G.S., C.J.H., lg. 91, fol. 229.

Hispania, LXIII/1, núm. 213 (2003) 75-136 
del consumo hicieron pensar que seguiría la misma tónica. Pero, por otro lado, también se estaba pensando en perpetuar oficios renunciables pagando una cantidad a la Corona y se van a vender cargos de ámbito estatal, como contadores y receptores del Consejo de Hacienda, entre otros. En la segunda década de este siglo (a partir de 1614 y hasta fines de este reinado) se van a perpetuar de modo masivo «por juro de heredad» regimientos, escribanías y otros cargos renunciables en Asturias, además de acrecentar otros ${ }^{52}$. Ver MAPA 2.

Del mismo modo, uno de los capítulos de Reformación de 1623 disponía la reducción a la tercera parte de los oficios allí donde, por ser excesivos, causaban graves daños; pero su aplicación fue escasa y, además, el cese de las ventas no fue total en los comienzos del reinado de Felipe IV. Al contrario, va a ser a partir de 1630 cuando llegue a su culmen la venalidad de oficios. Los gastos y el incremento de las deudas derivados de la política internacional de Olivares llevan a un aumento de la fiscalidad en todas sus formas. Las enajenaciones, con licencia del Reino, tienen por fin abonar al factor general, Bartolomé Espínola, los 600.000 escudos enviados a Flandes y Alemania, ventas que él gestiona directamente. Se le va a facultar la venta de un regimiento perpetuo en cada ciudad, villa y lugar del reino; igualmente un oficio de alguacil mayor en cada ciudad y villa, con voz y voto como los regidores, pero con preeminencia sobre ellos $^{53}$; desde comienzos de 1633 se le consiente vender las tesorerías y escribanías del servicio de millones. Nuevamente en 1634 se le concede a Espínola por vía de factoría la venta de un regimiento acrecentado y otros oficios para la paga de 1.290 .000 escudos y ducados. En 1635, tras la declaración de guerra de Francia, aumentan aún más los gastos. Con consentimiento de las Cortes, se sigue recurriendo a la venta de oficios en ese año y en los siguientes, tanto cargos de la administración central (contadores de Hacienda y de la Armada), como municipales.

En la Asturias de los años treinta se venden regimientos y escribanías de millones en la ciudad y en la mayoría de los concejos, así como la tesorería y la contaduría de millones y el alferazgo mayor del Principado ${ }^{54}$. Aunque la demanda de cargos va a ir poco a poco disminuyendo, sin embargo los precios de algunos alcanzan cifras verdaderamente exorbitantes dentro de un ambiente

52 A.G.S., C.J.H., Registros, lib. 363, 364 y 365.

53 La calidad de este oficio es similar al del alférez, inmediatamente tras él a todos los efectos y precediendo a los regidores en todos los actos públicos, pudiendo nombrar teniente que ejerciera el cargo y llevando las décimas de las ejecuciones a medias con el corregidor. Se trataba de facilitar las ventas y vender a precios altos a través de ofrecer calidades que antes no tenían los cargos y de evitar impedimentos debido a pujas y tanteos de los pueblos. Así, por ejemplo, a D. García de Doriga se le vende en 1634 un regimiento de Salas en 550 ducados con calidad de entrar con armas en el ayuntamiento, al igual que el alférez mayor y el alguacil mayor. A.G.S., C.J.H.., Registro, lib. 360. Con las mismas condiciones se vende a Juan de Palacios un oficio de regidor de Nava en 1635.

51 Tras petición de las Cortes, en 1647 se suprimieron las contadurías de millones, aunque la indemnización a los compradores corrió a cargo de las ciudades.

Hispania, LXIII/1, núm. 213 (2003) 75-136 


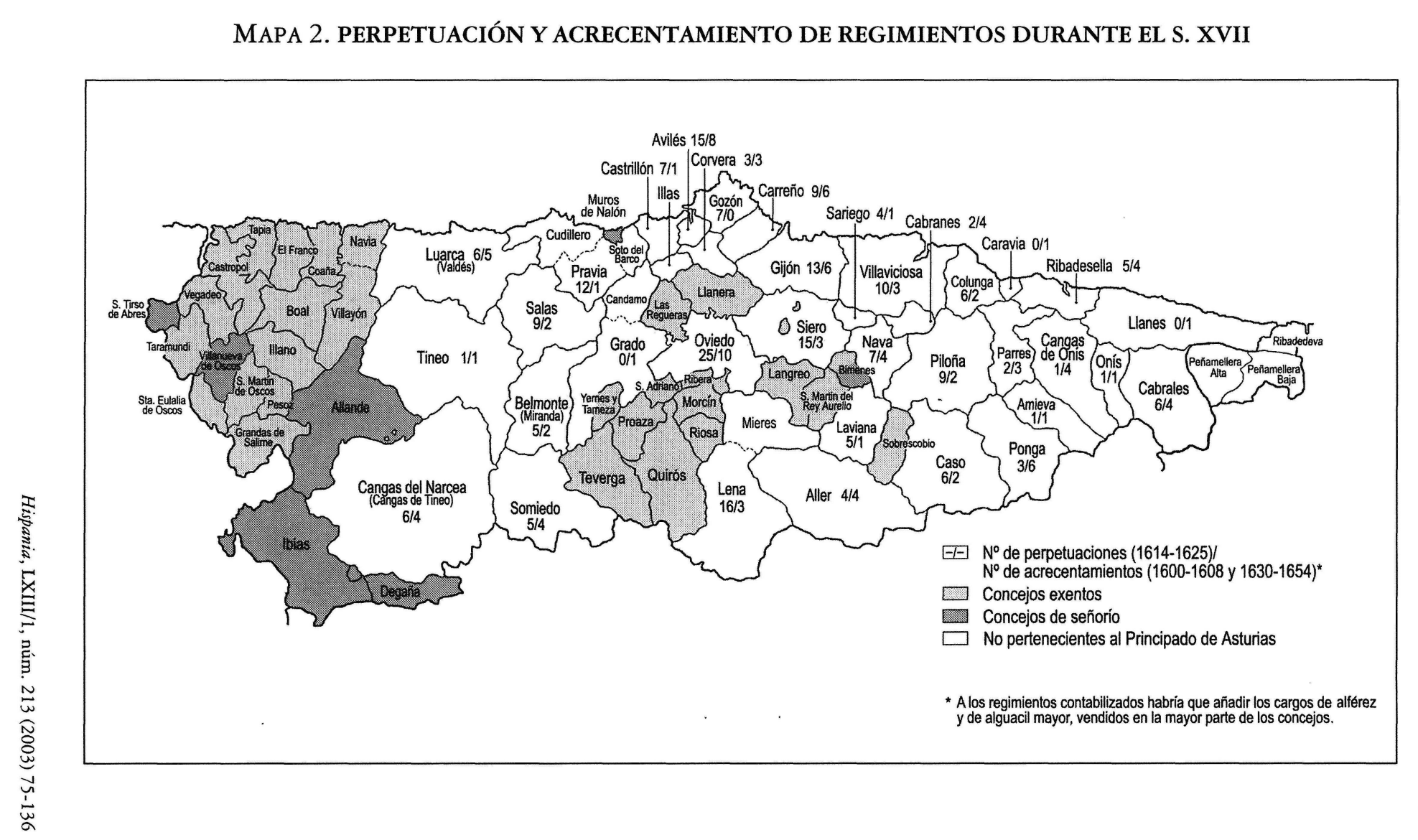


claramente especulativo55. Es de destacar la presencia de compradores que viven en la Corte, algunos de origen asturiano, tales como D. Alvaro Queipo de Llano (alferazgo mayor del Principado) ${ }^{56}$ y D. Fernando de Valdés (contaduría de millones). Se concede la preeminencia de que el cargo comprado no se pueda consumir, pujar ni tantear salvo si se ofrece el doble, aunque con un plazo amplio para ello $0^{57}$.

En 1638 las Cortes autorizan otra vez enajenar dos millones de ducados en oficios y jurisdicciones, de los que en 1643 aún no se habían vendido medio millón. Diversas prerrogativas justifican los altos precios. Así, por ejemplo, se quitan obstáculos que faciliten las renuncias: no hace falta que haya un plazo antes de la muerte como sucedía anteriormente; igualmente se vende el derecho a ejercer el cargo a través de un teniente. En los años 1639 y 1640 sigue la venalidad de cargos municipales, aunque Hacienda se queja de la debilidad de la demanda ${ }^{58}$. Desde los años cuarenta se enajenan, sobre todo, cargos estatales a precios muy altos (contadores de mercedes y de la Contaduría de Cuentas, contadores de resultas, Escribano mayor de rentas, los cargos de Portero, Relator y Alguacil mayor del Consejo de Hacienda, etc. $)^{59}$.

En los años cuarenta la venalidad de cargos continúa a menor ritmo y así sucede hasta final del reinado; a partir de 1645, año en que el Conde Duque fue apartado del gobierno, disminuyen las ventas de oficios en Asturias. No obstante, en 1646 las Cortes evaluaron haberse vendido en arbitrios 1.300 .000 ducados más de los dos millones otorgados por el Reino, de los que 156.000 lo fueron en oficios y jurisdicciones. Aún el rey consigue en 1655 la concesión por las Cortes de ventas de oficios, aunque no nos constan en Asturias ${ }^{60}$. En el reinado de Carlos II se vendieron pocos cargos, aunque algunos de gran valor: En

55 Sobre las ventas de 1630-1636 puede verse A.G.S., D.G.T., lgs 325, 326 y 1292 y C.J.H., Registro, lib. 366, 367 y 368.

56 D. Alvaro era gentilhombre de la boca del rey; se recuerda en el título concedido los servicios hechos a la Monarquía por su tío D. Fernando de Valdés, del Consejo de S.M. y arzobispo de Granada. Entre sus funciones está el ser teniente del gobernador en lo tocante a capitán de guerra de los 500 soldados con que debía servir el Principado. Además de voz y voto en la Junta, se le concede facultad de servirle con teniente; en 1661 al teniente se le van a dar las mismas calidades que al propietario. Los Queipo de Llano van a nombrar teniente en los Doriga y los Bernaldo de Quirós durante el siglo XVII. A.U.O., Casa Queipo de Llano, caja 36.

57 La cédula real para poder vender escribanías y tesorerías de millones permite la puja hasta seis meses después de la toma de posesión.

58 A.G.S., C.J.H., Registros, lib. 369.

59 Por este último cargo pagó Gómez de Angulo la cifra de 19.000 ducados. Sobre estos años pueden verse A.G.S., C.J.H., Registros, lib. 370, 371 y 372.

${ }^{60}$ Aunque no hemos encontrado registro en Simancas, sabemos que se crearon regimientos, así como que se vendieron tenencias a muchos regidores de la ciudad de Oviedo desde fines de los años treinta; de éstas siete se van a resumir en 1653 y otras veintiuna posteriormente. Igualmente se crearon escribanías; según Sangrador, se vendieron dieciséis, la mayoría desde 1640 a 1664. A.M.O, Libro Maestro de Fueros, fols. 107-108 y SANGRADOR, M.: op. cit., p. 152. 
Asturias sólo sabemos que en 1668 se vende el cargo de superintendente de fábrica, montes y plantíos del Principado de Asturias y de las Cuatro Villas de la Costa de la Mar. Las ventas van perdiendo credibilidad y los consumos, con o sin indemnización, van a dominar ya a partir de la Regencia.

Algunos pueblos respaldados por la legislación que permite el consumo de oficios van a acogerse a ella a lo largo de los reinados de Felipe III y Felipe IV; a la villa de Onís se le da consentimiento en 1624 para consumir sus regimientos perpetuos ${ }^{61}$. Pero sobre todo, será la ciudad de Oviedo y la Junta General del Principado quienes van a pleitear, tratando de conseguir la revocación o el tanteo de múltiples cargos, unas veces con éxito y otras no, como luego veremos.

\section{SOCIOLOGÍA DE LOS COMPRADORES}

En los primeros años de las ventas la nobleza trató de evitar la introducción en los gobiernos locales de nuevos elementos procedentes de estratos sociales inferiores, aunque en el caso asturiano - a diferencia de otras zonas de Castilla y Andalucía - no había plebeyos enriquecidos que les hicieran una competencia seria. A nivel general, las quejas sobre esta cuestión, de que se hacen eco las Cortes, fueron abundantes. En Asturias, hubo protestas sobre algunos compradores de alferazgos; Felipe II las va a tener en cuenta y, al menos en los primeros años de gobierno, va a pedir información sobre «la calidad» de los compradores de regidurías ${ }^{62}$. Nos consta que en 1561 el corregidor Pedro López de Mesa propuso para la perpetuación de regimientos a las personas principales de los concejos en la nómina que elaboró por petición de la Corona. Se va a requerir unas condiciones de edad, estado civil y vecindad, pero también un status social ${ }^{63}$. Pedro Argüelles de Meres dice en 1563 que se le concedió uno de los regimientos de Siero de los que S. M. hizo merced a «los hijosdalgo de las parcialidades e linajes del dho. concejo». En los títulos de estos años la Corona

${ }^{61}$ A.G.S., C.J.H., lg. 604.

62 La nobleza presiona en los primeros años de las ventas para evitar que se vendan cargos a personas que no sean «hábiles y suficientes». Así lo requiere en 1544 Diego García de Omaña al alcalde mayor Cangas, ante Lope González, escribano de Somiedo. A.G.H., Archivo Revillagigedo, casa de Omaña.

${ }^{63}$ Algunos solicitantes de estos cargos aducen ante el Consejo de Hacienda ser mayores de 25 años, estar casados en el concejo para el que solicitan y ser hijosdalgos notorios, personas principales y de solar conocido en el mismo. Entre los testigos interrogados por el corregidor está Gabriel Ordóñez que le advierte del peligro de que «podria ser que ydalgos e personas muy prencipales que ay ... quedasen sin oficios y los ubiesen otros que no fuesen de tanta calidad». Por su parte, Antonio de la Ribera, juez ordinario de la ciudad de Oviedo, aduce que en Oviedo los regimientos perpetuados los tenían "personas nobles, ricas y celosas de servir a Dios y a la republica y siendo estos es mejor porque ademas como no salen de sus oficios hay mas paz porque no se descuidan de la gobernacion». A.G.S., C.J.H., lg. 41, fol. 72.

Hispania, LXIII/1, núm. 213 (2003) 75-136 
asocia la quietud con la venta de los regimientos a «las personas mas ydoneas e suficientes y asistirian al gobierno y bien publico con mas asiento y cuidado» ${ }^{64}$.

Era admitido que el gobierno debía ser cosa de la nobleza; como dice Castillo Bovadilla, "poner el consejo y regimiento de la republica en poder de los plebeyos, y no escoger los nobles para ello, es quitar los ojos de la cabeça, y ponerlos en la cola ${ }^{65}$. La importancia del municipio, la categoría del cargo a enajenar y el consiguiente precio del mismo permiten, en gran medida, jerarquizar a la nobleza asturiana. Todos los hidalgos de solar van a aspirar a la compra de algún cargo de poder y, la mayoría lo van a conseguir, sobre todo en los primeros años de las ventas, debido a que los precios fueron más moderados. Hay que tener en cuenta que la compra de cargos traía para los compradores un beneficio económico, así como una mejor consideración social a nivel individual y en su status colectivo.

La demanda de oficios va a ser importante, incluso muchos se endeudan para comprar un cargo y algunos, finalmente, no podían pagarlo ${ }^{66}$. Pero algunos compradores no siempre van a ejercer el cargo. Hay una disociación entre la propiedad y el ejercicio del oficio debido a diversos motivos. A veces por recaer el cargo en una mujer o en un menor, otras debido a la acumulación de oficios (algunas familias compran varios en diversos concejos e, incluso en el mismo), o bien por residir lejos, a veces en la Corte. Además algunos cargos como escribanías, procuradurías o receptorías requerían una capacidad profesional a quien los compraba. Aunque por pragmática de 1589 se prohibe arrendar estos cargos y los propietarios debían servirlos ellos mismos o renunciarlos en el término de sesenta días, otra del año siguiente permite «darlos en confianza» por cierto tiempo. De cualquier modo, a pesar de ello, la cesión por dinero, aunque con subterfugios legales, va a terminar siendo frecuente.

A través de poner los oficios en cabeza de otros, de renuncias temporales o de escrituras de confianza se establecían redes de clientelismo, bien cediendo el cargo a un familiar, bien a "un criado o paniaguado». Muy a menudo las principales familias ponían el cargo en cabeza de una persona de su confianza, tanto regimientos como escribanías, a cambio de apoyo y favor. Felipe IV facilita las ventas ya que va a vender a los regidores la prerrogativa de poder poner teniente - sabemos que se hizo en la ciudad de Oviedo- y los nuevos cargos acrecentados incorporan en su título la calidad de «nombrar persona que le sirva y remo-

${ }^{64}$ A.U.O., Casa Argüelles, caja 47. También debió influir en el rey la recomendación dada por la junta de teólogos reunida por él y que aprobó la venta de oficios con la condición de que los compradores tuvieran las condiciones adecuadas.

65 Libro I, cap. IV, 35, Madrid, 1978, p. 59.

66 El capitán Bernardo de Valdés Alas, señor de la casa y solar del Ferrero, para pagar los 1.995 ducados que le costó en 1636 el alguacilazgo de Avilés y concejos anexos, hipoteca los bienes que tiene en el concejo de Siero de un valor superior a 2.500 ducados y que rentan más de 60 fanegas de pan al año, así como las casas que posee en Oviedo valoradas en más de 3.000 ducados.

Hispania, LXIII/1, núm. 213 (2003) 75-136 
verlo con causas o sin ellas ... con solo el nombramiento del propietario aya de ser admitido a dicho oficio sin necesidad de otro titulo ni despacho alguno».

El corregidor de Oviedo, Dr. Pernia, informa al Consejo de Hacienda en 1581 que

«si pretende vender algunos oficios aunque la tierra es misera y esta fatigada con compras de juridiçiones eclesiasticas que an hecho y otras cosas pero como la gente de su ynclinacion es anbiciosa y an vindicativa unos con otros no dexara de aber algunos conpradores ${ }^{67}$.

De los cargos se obtiene prestigio, influencia y poder, pero también una renta, porque a veces se ceden por dinero ( caso frecuente en el caso de las escribanías). Además los salarios anuales no son tan despreciables como se dice. A la tesorería de alcabalas se le asignan 100 ducados en 1567, la contaduría de millones se vende en 1639 con un salario de 133 ducados, el cargo de alguacil de millones del Principado tiene en 1652 unos 200 ducados anuales, el salario que se da al tesorero de millones en 1636 es de 44 ducados y el del merino y alcaide de la cárcel de Oviedo es de 40 ducados al año percibidos sobre las penas de cámara; por su parte, a los alguaciles mayores se les asigna la mitad de las décimas de las ejecuciones y denuncias, incluso cuando iban ante el gobernador del Principado.

Pero los compradores de oficios tenían además otras intenciones. Nos consta que los abusos fueron frecuentes en el ejercicio de muchos cargos y evitarlos fue la principal causa de los pleitos, tanteos y consumos que iniciaron los pueblos. Las Cortes de 1586 piden el cese de las ventas de regimientos y escribanías

«porque los compradores se hacen dueños absolutos de los pueblos y usurpan los propios, leña, dehesas y pastos comunes, y se aprovechan de los panes y viñas de particulares sin que la gente prove les pueda ir a la mano» 68 .

Castillo Bovadilla ratifica esta situación en Política para corregidores y señores de vasallos cuando dice

«ien qué se funda el que vende toda su hacienda para comprar un regimiento?... Fácil es responder, que lo hace para traer sus ganados por los cotos, para cortar los montes, cazar y pescar libremente ... para ser regatones de los mantenimientos y otras cosas en que ellos ponen los precios; para vender su vino malo por bueno y más caro y primero; para usurpar los propios y pósitos y ocupar los baldíos» ${ }^{69}$.

\footnotetext{
67 A.G.S., C.J.H., lg. 192, fol. 1.

${ }^{68}$ Actas de las Cortes, t. V. Citado por Domínguez OrTiz, A.: «La venta de cargos...», art. cit., p. 113.

69 Bovadilla, C.: op. cit., t. II, lib. III, cap. VIII, 286.
}

Hispania, LXIII/1, núm. 213 (2003) 75-136 
Igualmente Caxa de Leruela dice que

«la mayoría de las licencias para romper dehesas de Propios y Comunes se introducen para pagar los tanteos, compras y consumos de oficios públicos y para otros fines a que se mueven los poderosos por sus particulares intereses, puesto que para sus ganados ha de haber pastos aunque perezcan los demás»70.

Los estratos más altos de la nobleza asturiana compraron oficios por motivo de lustre o vanidad, pero también de provecho. En 1562 el corregidor Pero López de Mesa contesta a S.M. que las quejas de muchas personas no propuestas para la perpetuación de los cargos añales no le sorprenden; dice

«no tengo por cosa nueva que los asturianos se agravien mayormente en negocio que pretenden sacar ynteres y de ninguna cosa que azerca desto se provea se dexaran de agraviar las personas a quien no se dieren los oficios» ${ }^{71}$.

Creemos que uno de los motivos de las compras de regimientos en Asturias fue, sin duda, la posibilidad de aprovecharse de comunales y pastos, especialmente en los concejos de montaña $a^{72}$. Los abusos y situaciones paraseñoriales durante todo el Antiguo Régimen, de las que se quejan los pueblos asturianos, se amparan, en gran medida, en la posesión de oficios de poder por las principales familias. La estrategia, tan frecuente, de comprar cargos en los mismos concejos donde tenían intereses económicos nos ratifica en esta aseveración.

La calidad de los compradores de escribanías no es muy distinta a la de los regimientos, aunque dados sus precios generalmente más bajos, el espectro social es más amplio. La capa alta de la sociedad asturiana es una nobleza media, que compra este cargo que también da influencia y prestigio. Muchos linajes adquieren escribanías, poniéndolas en cabeza de otros o cediéndolas a algún familiar ${ }^{73}$. Aunque algunos de los mayorazgos de las principales casas asturianas eran escribanos, renuncian en otros por ser incompatible este oficio con el de regidor.

La nobleza codicia los oficios porque le facilitan el ascenso social y porque le permiten establecer un poder duradero en el gobierno municipal. Los pueblos van a quedar a expensas de los intereses de unos pocos aún más que antes. Tener un regimiento en la ciudad es el mayor anhelo de las élites locales; en 1544 y años

70 Restauración de la abundancia de España (1632), p. 94, edic. de 1732.

${ }_{71}$ A.G.S., C.J.H., lg. 46, fol. 198.

72 En el título de un regimiento de Caso comprado en 1588 se explicita que si el titular renuncia en otra persona que no sea vecina del concejo, ésta sólo pueda llevar ganado a los pastos como un vecino más. La compra de regimientos en Babia de Yuso y de Suso que tan frecuentemente realizan los Miranda, los Flórez y los Bernaldo de Quirós también hay que interpretarla en este sentido.

${ }_{73}$ Así, por ejemplo, el general Diego Flórez de Valdés, caballero de Santiago, deja en 1595 por testamento la escribanía que tenía en Somiedo a Juan Gómez con la condición de que se casase con la hija de $\mathrm{D}^{\mathrm{a}}$ Catalina de Castro, hermana del testador. A. G. H., Archivo Revillagigedo, casa de Las Morteras, ms. 165, 1. 4, n. 15.

Hispania, LXIII/1, núm. 213 (2003) 75-136 
siguientes los que compran regimientos en Oviedo son los linajes que ya ejercían anteriormente el gobierno como jueces o regidores. Junto con familias tradicionalmente afincadas en Oviedo (la Rúa, los Oviedo) ya consta en estos años la presencia de otras casas con solar en otras zonas asturianas, tales como los Ramírez, los Carreño, los Solís y los Argüelles ${ }^{74}$. El acrecentamiento de regimientos va a permitir el afianzamiento de algunas familias, así como el acceso al gobierno de la ciudad de otras foráneas, proceso que va culminar a mediados del siglo XVII.

Igualmente interesa a la nobleza ejercer oficios con voz y voto en los concejos donde tiene intereses económicos ${ }^{75}$. Esta estrategia que van a practicar algunas familias de la nobleza, sobre todo las que tienen mayor patrimonio económico, va a ser facilitada por la venta de oficios por parte de la Corona. Los más demandados - $-\mathrm{y}$, por tanto, los de precio más alto - son los oficios de la capital y de los concejos de la zona central de Asturias, la de mayor vitalidad económica, pero también son muy codiciados los de los concejos con brañas y abundantes pastos.

Aunque la situación varía en función de estrategias y avatares de las distintas casas a lo largo del tiempo, podemos decir que los Miranda tuvieron cargos municipales en los concejos de Oviedo, Pravia, Avilés, Somiedo (alferazgo), Miranda, Salas, Tineo y Cangas de Tineo; los Bernaldo de Quirós en los municipios de Oviedo, Aller (alferazgo), Lena, Laviana, Somiedo, Avilés, Corvera y Siero; los Argüelles de Meres, aparte de Oviedo, adquirieron cargos en Siero, Gijón, Aller, Lena, Sariego y Caso y los Argüelles de Celles en los de Oviedo, Gijón, Siero, Laviana, Avilés y Valdés ${ }^{76}$. Los Vigil compraron en diversos momentos oficios en Oviedo, Gijón, Villaviciosa, Siero, Nava (alferazgo), Sariego, Aller y Caso; los Menéndez de Avilés contaron con oficios en Oviedo, Avilés, Pravia y Lena; los Doriga en Oviedo, Pravia, Salas y Miranda ${ }^{77}$; los Cienfuegos

${ }^{74}$ D. Pedro de Solís va a comprar en 1558 el alferazgo de Oviedo por 1.000 ducados; aunque la ciudad va a entablar pleito para lograr la supresión de un cargo que tenía preeminencia sobre el resto de los regidores, los Solís van a conseguir mantenerlo. La casa de Solís, con solar en Corvera, va a contar también con regimientos en Corvera y Avilés. El ascenso de esta casa hay que hacerlo partir de D. Pedro de Solís, protonotario del papa Alejandro VI, arcediano de la catedral de Toledo, Deán de la catedral de Oviedo, maestrescuela de la catedral de León, abad de Santa Marta de Astorga y abad de Santa María de Arbás, que funda mayorazgo a favor de su primo Gutierre de Solís en 1510; igualmente hay que tener en cuenta las compras de casas y bienes rústicos del citado $\mathrm{D}$. Pedro y del hijo de Gutierre, Boiso Suárez de Solís.

75 Aquellas casas que tienen su patrimonio rústico más disperso son las que tienden a acumular cargos de distintos concejos. Las que lo tienen más concentrado no ven esa necesidad; es el caso de la casa de Ramírez, que a pesar de su importancia, únicamente tuvo regimientos en Oviedo, Gijón y Siero.

76 En 1635 Diego Argüelles Junco (de la casa de Vega de Poja) tiene incorporado a su mayorazgo un regimiento en Oviedo, dos en Siero (en cabeza de Alonso de Novalín y de Domingo Gutiérrez), dos en Cabranes y medio en Nava y acababa de comprar un regimiento añadido en Nava (lo pone en cabeza de Juan de Palacio de Tiroco) y parte de dos oficios - también añadidos - de Siero (están en cabeza de Bernabé Vigil el viejo y de Bernardo de Asón el mozo). Posee además una escribanía de número y puridad en el concejo de Siero y otra en el de Nava. A.U.O., Casa de Argüelles, caja 1.

77 Fernán García de Doriga paga 712 ducados en 1614 por la perpetuidad de cinco regimientos que tenía (dos en Salas y uno en Oviedo, Pravia y Miranda) y tres escribanías (dos en Grado y una en Salas).

Hispania, LXIII/1, núm. 213 (2003) 75-136 
en Aller, Lena y Pravia; los Carreño en Oviedo, Avilés, Carreño y Castrillón y los Oviedo en Oviedo, Gijón y Siero.

Mientras los linajes y casas citadas tuvieron, gracias a la posesión de oficios poder e influencia en amplias zonas del Principado, otras, en cambio, tuvieron una proyección más local, centrada básicamente en el concejo donde tenían su solar y residencia. Así podemos destacar en Avilés los Alas y los León; en Gijón los Jove, los Llanos y los Valdés; en Villaviciosa, los Hevia y los Solares; en Nava, la casa de Nava; en Pravia, los Cuervo, los Inclán, los Arango y los Salas; en Miranda los Leiguarda ${ }^{78}$, en Salas, las casas de Malleza y de Salas. Los Flórez (casa de Las Morteras) cuentan con oficios en Somiedo, Miranda (alferazgo) y Babia.

En la zona oriental de Asturias destaca, en primer lugar, la casa de EstradaNevares; con solar en Parres, tiene oficios en este concejo y en los de Cangas de Onís y Onís (alferazgo en ambos), Llanes y Colunga; los Caso tienen cargos en Caso (alferazgo), en Piloña y en Ponga y los Junco en'Ribadesella (alferazgo), Colunga (alferazgo) y Parres. Otras casas menores, como los Posada tienen el alferazgo y otros oficios en Llanes, Cabrales y Onís y la de Cutre en Caravia (alferazgo) y Colunga ${ }^{79}$.

En la zona occidental de Asturias podemos destacar a los Avello en Valdés y los Sierra, los García de Tineo, los Queipo de Llano y los Omaña en Cangas de Tineo y Tineo. Los Omaña contaron asimismo con regimientos en los concejos de Somiedo y Pravia, en los que estaban inclusos cotos de su propiedad ${ }^{80}$.

La concesión del oficio de alférez mayor del Principado en 1636 a Alvaro Queipo de Llano, gentilhombre de boca del rey, es un ejemplo de favor real a un noble asturiano con influencia en la Corte, del que se espera que, desde su nuevo cargo, pueda controlar la Junta General ${ }^{81}$. Pero este linaje ya había comprado en los años ochenta del siglo anterior varios regimientos en los con-

78 Varios miembros de la familia compraron en 1583-1584 un regimiento, la depositaría general y una escribanía, oficios perpetuados en 1614 .

79 Tienen su poder establecido en un concejo: los Prieto en Ribadesella, los Covián en Colunga, los Intriago en Cangas de Onís, los Labra y los Cebos en Onís, los Arenas en Cabrales y los Soto en Amieva. A menudo eran escribanos de esos concejos. Hemos cotejado y completado la documentación de Simancas con los archivos particulares de las casas de Labra, González Cutre, Posada Herrera y Estrada-Nevares.

80 Sabemos que la casa tuvo dificultades para pagar a fines del s. XVI. Por cédula real de 1599 se pide a $\mathrm{D}^{\mathrm{a}}$ María Rodríguez, viuda de Arias de Omaña, que pagase 600 ducados que debía por los tres regimientos que quedaron vacantes a la muerte de aquél; ella pide rebaja en el precio. El regimiento de Tineo fue comprado a Ares González del Riego en 300 ducados (año 1616) por D. Lope de Omaña y el alferazgo de Cangas de Tineo pasó en 1585 a Arias de Omaña por renuncia de su suegro Diego Flórez de Valdés. A.G.H., Archivo Revillagigedo, casa de Omaña.

81 Para dificultar los pleitos que pudiera plantearle la Junta General, por provisión del Consejo de Castilla de 1643 se dice que no podrán pagarse con propios y rentas del Principado ni repartiendo dinero entre los vecinos. La posición de poder de su propietario le permitirá mantenerse en el cargo a pesar de los pleitos que la Junta litigó en los años cuarenta y sesenta. Igualmente por otra provisión del Consejo se declara en 1670 no estar incluido el alferazgo en la extinción de oficios decretada el año anterior. A.U.O., Casa Queipo de Llano, caja 36.

Hispania, LXIII/1, núm. 213 (2003) 75-136 
cejos de Tineo y Cangas de Tíneo y en 1640 D. Diego Queipo de Llano y Flórez compra el alguacilazgo mayor de este último concejo ${ }^{82}$.

\section{LOS PRECIOS DE LOS OFICIOS}

La venta de cargos en el Principado de Asturias va a realizarse, ya desde el principio, a unos precios mucho más bajos que en otras zonas de Castilla y Andalucía. Así en 1557 el precio de un regimiento era de 3.200 ducados en Sevilla, 2.200 en Córdoba, 1.800 en Toledo, 1.300 en Burgos y 750 en Madrid, mientras en Oviedo costaba solamente 200 ducados $^{83}$.

La base para el establecimiento del precio era la vecindad e importancia económica del municipio. Así, por ejemplo, los precios de los regimientos oscilan en 1583 entre los 320 ducados en Gijón y los 80 de Piloña o Ponga y las perpetuaciones de 1614 entre los 225 ducados de Oviedo y los 20 de Ponga. El Consejo de Hacienda establecía los precios en base a los últimos vendidos, pero también influye en el valor la demanda que tuviera dicho oficio; se aceptaban pujas y finalmente se remataba el cargo en quien ofreciera el precio más alto. A partir de 1630 se vendieron los regimientos con la condición de no aceptar pujas, a no ser que se doblara la cantidad ofrecida por el primer comprador.

La demanda de cargos fue importante en general y explica la subida de los precios a lo largo del tiempo. Este aumento de los precios es menor en los comienzos de las ventas ${ }^{84}$, pero ya relevante desde comienzos del reinado de Felipe II. Para explicar los bajos precios en las primeras operaciones de venta masiva de oficios realizadas por la Corona hay que tener también en cuenta los escrúpulos reales, que se observan incluso en cómo se facilita a los compradores el pago en Oviedo, tratando de evitar las costas de ir a la Corte. Aunque las pujas hicieron subir mucho el precio de algunos alferazgos en 1558, no obstante el Consejo de Hacienda decide que si lo hacían en demasía no se vendiesen finalmente a nadie ${ }^{85}$. El propio Felipe II reconoce en 1583 que los precios de los oficios habían sido anteriormente demasiado bajos.

Pero a pesar de lo dicho, debemos decir que los precios van subiendo a lo largo del siglo en que se aplicó este arbitrio. Esta evolución se puede apreciar

82 En 1766, procedentes de compras a la Corona o a particulares, cuentan los Queipo, aparte del alferazgo mayor, con el alferazgo de la villa de Cangas, un regimiento en Cangas de Tineo y dos escribanías, una en cada uno de los dos concejos citados. A.U.O., Casa Queipo de Llano, caja 11.

83 A.G.S., C.J.H., lg. 35, fols. 224-226 y 231 bis y lg. 38, fol. 153.

${ }^{84}$ Se puede comprobar, a nivel general, en las respuestas dadas por los corregidores en 1545 , tras averiguar los posibilidades de venta; dicen que no hay dinero y que lo que se ofrecía por los cargos eran cantidades irrisorias. A.G.S., Diversos de Castilla, lg. 47, fol. 33.

85 El alferazgo de Llanes recibió durante 20 días, fecha tope para el remate, diversas posturas por parte de Hernando de Estrada y de Juan de Posada el mozo que le llevó a un precio final de 640 ducados. El Consejo de Hacienda había decidido que si subía de 800 ducados no se vendiera a nadie a ningún precio. A.G.S., C.J.H., lg. 34, fol. 425-426.

Hispania, LXIII/1, núm. 213 (2003) 75-136 
especialmente en la ciudad de Oviedo donde las principales familias desean tener un regimiento; así durante la segunda mitad del siglo XVI los precios pasan de 150 ducados en 1544 a 900 en 1600; mientras en Avilés suben de 150 a 250 entre 1544 y 1594 y en Villaviciosa de 100 a 180 entre 1544 y 1602. Evolución similar puede observarse en los precios de venta de las escribanías y del resto de los oficios.

Las perpetuaciones de la segunda década del siglo XVII (a partir de 1614) se hicieron a aquellos tenentes de cargos renunciables que así lo solicitasen, fijando su valor en la cuarta parte del precio en que se vendían en ese momento los oficios de los citados concejos. Podemos decir, por tanto, que los precios de estas perpetuaciones fueron bajos, razón por la que interesó a muchos poseedores de cargos y las ventas fueron masivas.

A partir del reinado de Felipe IV los precios de los oficios van a subir de modo importante ${ }^{86}$. Además en 1631 se crea la media annata y los compradores de un cargo deben pagar el 2,5\% del precio del mismo. Pero aparte de este tributo en 1635 los precios llegan a su culmen dentro de un ambiente de fuerte demanda y claramente especulativo: los regimientos suben en Oviedo a 2.600, en Avilés a 800 y en Villaviciosa a 600. Del mismo modo, se van a satisfacer fuertes cantidades por cargos creados de gran relevancia: por el alferazgo mayor del Principado pagó D. Alvaro Queipo de Llano 5.280 ducados, por la contaduría de millones, D. Fernando de Valdés 2.540 ducados, por la tesorería de millones, Juan López Leonel 3.301 ducados y por la escribanía de millones de Oviedo, Alonso Balbín 1.450 ducados.

Hay que tener en cuenta que en los años treinta se aceptan únicamente pujas del doble de la cantidad ofrecida por el primer postor; por esta causa los precios pueden llegar a ser altos, pero también muy variables dentro de un mismo concejo y poco proporcionales a los precios a que solía venderse. Así, debido a las pujas, Gregorio de Vigil llega a pagar por el regimiento vendido en Oviedo 2.600 ducados, por el de Cangas de Tineo, Francisco de Sierra de Jarceley 1.066 ducados y por el de Llanes, Francisco de Meneses, guardamantel de S.M., 1.000 ducados; y en Lena se venden en 1635 dos regimientos uno a 500 y otro a 700 ducados; la especulación y las rivalidades entre las diversas familias ayudan a explicar los diversos valores ${ }^{87}$.

A partir de los años cuarenta los precios van a bajar. Hay una menor demanda de oficios que deriva del excesivo número de los ya existentes y de su consiguiente descrédito, en una época en la que, además, se va a ir imponiendo

${ }^{86}$ Con datos de varias ciudades y villas castellanas y andaluzas, J.E. Gelabert confirma la fuerte subida de precios a partir de 1630. "Tráfico de oficios...», en Ciudad y mundo urbano ..., op. cit., pp. 165-167.

87 Así, Pedro Suárez de Tapia compró en 1630 un regimiento de Valdés en 544 ducados, pero pujó Juan García de Castrillón por 1.500 ducados. Igualmente Francisco Bernaldo de Quirós compró la tesorería de millones en 2.200 ducados, pero Juan López Leonel ofreció 3.301, aunque finalmente éste no lo pudo pagar y se remató en Manuel Enríquez en 1.235 ducados.

Hispania, LXIII/1, núm. 213 (2003) 75-136 
el consumo de cargos que culmina con la legislación abiertamente a favor de comienzos del reinado de Carlos II.

\section{MONTO ECONÓMICO DE LAS VENTAS}

En primer lugar, debemos tener en cuenta la evaluación global que sobre la venta de oficios en la corona castellana aportan M. Ulloa y M. Cuartas. Referido al reinado de Felipe II y limitado a 28 años de reinado (entre 1560 y 1597) Ulloa da una cifra de 2.126.582 ducados. M. Cuartas en un arco cronológico más amplio (de 1543 a 1599 y para 40 años) cita unos ingresos totales de 3.274.719 ducados ${ }^{88}$. De cualquier modo, ambos autores consideran que los valores de muchas ventas no ingresaron en la Tesorería General, hecho que hemos podido comprobar. Domínguez Ortiz cita un cálculo hecho en 1600 por el que subirían a unos doce millones de ducados las ventas de oficios realizadas ${ }^{89}$. Asimismo estima en 30.000 el número de propietarios de oficios en 1650. El cálculo de la gran oleada de ventas a partir de 1630 es difícil de realizar por haberse excedido las cantidades concedidas por las Cortes. Sin duda las ventas de los años treinta y cuarenta llegan a valores muy altos. Solo en 1646 se estima en 585 cuentos de maravedís lo vendido en oficios y jurisdicciones.

Nuestra intención ha sido realizar una cuantificación del monto global de las ventas en Asturias. A pesar del importante número de legajos consultados y del cotejo de diversas informaciones no hemos podido encontrar el registro de todas las ventas. Las cifras dadas, tal como se refleja en el cuadro adjunto, están siempre por debajo del valor total de las enajenaciones llevadas a cabo.

De los valores totales que hemos contabilizado de las ventas en Asturias (281.214 ducados) podemos deducir el beneficio que sacó la Corona, sin contrapartidas ni a corto ni a medio plazo desde el punto de vista económico. La provisión de cargos vacantes hasta las perpetuaciones realizadas por Felipe III, así como la percepción de la media annata sobre los cargos vendidos o transmitidos en herencia durante el reinado de Felipe IV van a traer otros ingresos para la Hacienda real. En el cuadro puede verse también de modo cuantificado la diferente utilización del arbitrio de la venta de cargos por los diversos Austrias, mayor con Felipe II y con Felipe IV, tal como ya hemos dicho anteriormente.

En cambio, hay que constatar el perjuicio que trae la salida de estos capitales para la economía del Principado. Además hay que tener en cuenta - aparte de las consecuencias políticas derivadas de la creciente oligarquización- los costes económicos directos e indirectos que trae para el conjunto de la sociedad asturiana. El perjuicio social deriva muy especialmente de los pagos resultantes

${ }_{88}$ UlLOA, M.: La Hacienda real de Castilla en el reinado de Felipe II, Madrid, 1986, p. 656 y CuARTAS, M.: «La venta de oficios públicos en el siglo XVI», art. cit., pp. 258 y 259.

89 «La venta de oficios...", art. cit, p. 131. 
de los pleitos entablados con la Corona y del tanteo y consumo de oficios por parte del Principado, de la ciudad de Oviedo y otros concejos, los salarios que perciben tantos magistrados, abusos de muchos poseedores de cargos, extorsiones que hay que extender a los que compraron cargos «de dinero», que suponen en conjunto cantidades importantes aunque difíciles de contabilizar.

\section{CUADRO 1. MONTO ECONÓMICO DE LAS VENTAS POR REINADOS Y POR OFICIOS}

\begin{tabular}{|l|c|r|r|r|r|}
\hline OfICIO & CARLOS V & FELIPE II & FELIPE III & FELIPE IV* & $\begin{array}{r}\text { TOTALES } \\
\text { (DUCADOS) }\end{array}$ \\
\hline Regimientos & 8.480 & 57.918 & 21.510 & 60.341 & 148.249 \\
\hline Alferazgos & - & 16.435 & - & - & 16.435 \\
\hline Depositarías & - & 6.983 & 2.490 & 296 & 9.769 \\
\hline Alguacilazgos & - & - & - & 14.634 & 14.634 \\
\hline Alcaidías & - & 2.050 & 1.342 & 3.772 & 7.164 \\
\hline $\begin{array}{l}\text { Tesorerías y } \\
\text { receptorías }\end{array}$ & - & 3.035 & 1.700 & 3.301 & 8.036 \\
\hline $\begin{array}{l}\text { Fieldades y } \\
\text { corredurías }\end{array}$ & - & 3.575 & 983 & 1.063 & 5.621 \\
\hline Procuradurías & - & 1.600 & 4.308 & 1.088 & 6.996 \\
\hline Escribanías & 1.030 & 32.006 & 8.034 & 21.540 & 62.610 \\
\hline Otros & - & - & - & 1.700 & 1.700 \\
\hline TOTALES & 9.510 & 123.602 & 40.367 & 107.735 & 281.214 \\
\hline
\end{tabular}

* A falta de datos sobre las tenencias de regimientos de Oviedo vendidas, hemos contabilizado el valor del resumen de esas tenencias (3.398 ds.).

Pero, en base a estos datos, también podemos intuir lo que supuso la venta de oficios para el conjunto de la sociedad castellana. Además a las importantes detracciones a través de este arbitrio vienen a sumarse las realizadas por otras vías. La presión fiscal directa e indirecta fue muy fuerte y tiene unas consecuencias muy negativas para la evolución económica y social y ayuda a explicar el endeudamiento y la decadencia del municipio ${ }^{90}$. La política hegemónica seguida en Europa, a la que va destinado el dinero reucaudado, trajo un esfuerzo sin contrapartida.

${ }^{90}$ La ciudad de Logroño pidió licencia a Felipe III para tomar a censo y echar en sisa 26.000 ducados para consumir 24 regimientos y 1 escribanía, que le fue concedida, aunque finalmente no pudo soportar esta deuda. A.G.S., C.C. Oficios, lg. 18. Igualmente la ciudad de Segovia dio 23.500 ducados en 1616 por varios oficios de corredores y fieles. Estos mismos cargos redimen la ciudad de Burgos y las villas de Pareja, Castro Urdiales y Laredo. A.G.S., C.J.H., lgs. 604 y 548. 


\section{LA OPOSICIÓN A LA ENAJENACIÓN DE OFICIOS}

La perpetuación y acrecentamiento de oficios va a ocasionar una amplia oposición tanto a nivel institucional como social. Tiene muchas implicaciones tanto de carácter político como económico y social: merma atribuciones a las instituciones locales frente al poder central, rompe el equilibrio de poder existente a nivel local, ya de por sí frágil, supone fuertes desembolsos para los compradores y para los municipios y pesa, en definitiva, sobre todos los grupos sociales. Además, los acrecentamientos suponen un perjuicio para los tenentes de oficios, una depreciación de los cargos existentes (sobre todo cuando se dan preeminencias sobre el resto del colectivo o cuando se asignan a esos nuevos cargos atribuciones que ejercían otros) y ocasionan un daño económico, especialmente patente en las escribanías ${ }^{91}$.

Las Actas de las Cortes castellanas son un buen indicador del malestar de la sociedad castellana ante el acrecentamiento y perpetuidad de los cargos municipales. Benjamín González Alonso hace un análisis de esta oposición, que rastrea desde 1544 a 1588 , coincidiendo sobre todo con los momentos álgidos de ventas ${ }^{92}$. La insistente petición de que los pueblos pudieran consumir los oficios fue escasamente atendida por Felipe II $^{93}$.

La Junta General fue un vehículo de oposición del Principado de Asturias a los diversos arbitrios aplicados por los Austrias. Aunque conocemos mejor su actuación en el s. XVII, ya desde comienzo de la venta de oficios se va a pronunciar la Junta. En 1558 y años siguientes fueron especialmente protestadas las ventas de alferazgos; se quiere que cesen y se revoquen las ya hechas.

En 1559 el corregidor D. Hernando de Torres hizo una información a través de testigos y la envió al Consejo de Hacienda. Los argumentos aducidos en ella son varios: que muchos compradores no eran vecinos del concejo donde habían comprado la alferecía, que el pago de su salario era una carga para los vecinos, que algunos eran personas de «poca calidad» y se dedicaban a prácticas comerciales; del comprador del alferazgo de Villaviciosa, Antón Arias, se dice que, además de vender mercadurías prohibidas, era hijo de cristiano nuevo. Igualmente se hace mención al conflicto de competencias que en lo militar había entre los nuevos cargos y la Junta del Principado, así como al desequili-

${ }^{91}$ Las quejas de los escribanos sobre el perjuicio económico que les traía el acrecentamiento de su número son abundantes en el Consejo de Hacienda y crecientes en el tiempo. Los escribanos antiguos deben repartir con los nuevos los derechos que llevaban. Se llegó a un aumento desorbitado en muchos municipios; a veces los poderosos compraban las escribanías que la Corona vendía (otras veces incluso solicitaban el acrecentamiento) como una forma de asegurar su poder en uno o varios concejos y luego las cedían gratuita u onerosamente. Pueden verse quejas de escribanos asturianos en A.G.S., C.J.H., lgs. 87, 94, 105, 119 y 188.

92 "Notas sobre los acrecentamientos de oficios...", art. cit. En realidad, ya en 1523 había habido un intento de ventas, tal como denunciaban las Cortes de ese año.

${ }_{93}$ En 1573 se autoriza el rescate de las fieldades, en 1582 la posibilidad de tantear los alferazgos si sus propietarios accedían y en 1588 que las aldeas puedan tantear los regimientos vendidos.

Hispania, LXIII/1, núm. 213 (2003) 75-136 
brio que se producía en los municipios por la posición superior que habían adquirido respecto al resto de los regidores y que, de hecho, ya había traído manipulación de elecciones y prácticas de corrupción ${ }^{94}$. En este sentido, también se argumenta que «muchos caballeros pobres principales» quedaban sometidos al alférez y ello llevaría a «enojos y odios» ${ }^{95}$.

Efectivamente se produjo un desequilibrio en el reparto del poder municipal y, consecuentemente, una desestabilización, fuente de conflictos. Lógicamente los compradores del cargo no opinan lo mismo que el resto de la capa alta de la hidalguía local, ya que lograron con la compra más prestigio y poder y, por tanto, están a favor de la permanencia de los nuevos cargos. Así Sancho de Miranda considera que el oficio proporciona una mayor estabilidad y un mejor gobierno en los concejos, ya que muchos regidores, dice, no sabían leer ni escribir. Felipe II ante una oposición tan fuerte escribe al corregidor unos días antes de las elecciones de 1559 diciéndole que los concejos del Principado eligen los oficios por suertes y algunos alféreces pretenden elegir por sí mismos sin entrar en suertes, por lo que "podria ser que suçediesen muertes y questiones y otros daños»; por esta razón, manda que ese año no entren los alféreces en las elecciones, sino que se hagan como antes; en 1560 va a prorrogar esta orden ${ }^{96}$.

Pero en vez de suprimir los alferazgos el rey decide perpetuar los regimientos de los concejos donde había alferazgos. Este tema va a ser debatido en la Junta de 21 de febrero de 1561 y la mayoría de los procuradores fue de la opinión de pedir nuevamente la supresión de los alféreces y que no se vendiesen los regimientos; sólo Gutierre de Hevia creía una solución contrarrestar el poder absoluto que tenían aquéllos con la perpetuación de los regimientos ${ }^{97}$.

En 1573 la Junta solicita al rey que suprima los cargos de fieles ejecutores que había creado en la ciudad y que no los provea en el resto de los concejos. En el poder dado para ir a Madrid argumenta que «la tierra es pobre y miserable» y los compradores caballeros y personas principales «de quien los pobres vasallos seran molestados e echoles muchas vexaciones»; también aduce «el odio que entre los particulares ay» y «la gran utilidad e provecho quietud e sosiego vendra a esta ciudad y Principado». La ciudad es quien finalmente se va a hacer cargo de su redención ${ }^{98}$.

${ }_{94}$ El licenciado Valdés pide que se perpetúen los regimientos de Illas y para ello aduce los abusos y prepotencia de Fernando de las Alas, que con el título de alférez de Avilés se entromete en las elecciones del concejo; cree que la perpetuación de los regimientos sería la solución a esta situación. A.G.S., C.J.H., lg. 94, fol. 96.

${ }^{95}$ MENÉndeZ, A.: «La venta de oficios públicos en Asturias en los siglos XVI y XVII», en BIDEA, $112(1984)$

${ }^{96}$ A.G.S., C.C., Ig. 23. A fines de 1558 el rey acepta la petición que le había hecho el concejo de Siero; éste se había quejado del daño que traía que Diego de Santillana, comprador del alferazgo, fuese elector ya que se había confabulado con otros y pedía que se resumiera el oficio. A.U.O., Casa Argüelles, caja 47.

97 A.G.S., C.J.H., lg. 41, fol. 72.

98 A.G.S., C.C., lg. 23 ( sesión de 25-9-1573).

Hispania, LXIII/1, núm. 213 (2003) 75-136 
A lo largo del siglo XVII la venta de oficios fue una preocupación de la Junta, pero también lo fueron otros expedientes utilizados por los reyes para arbitrar dinero. Así entre los años 1609 y 1613 se va a pronunciar en varias ocasiones en contra de la venta de alcabalas y hace diligencias en Madrid para evitarla aduciendo el daño que ocasiona ${ }^{99}$. Igualmente sucede con la pretendida venta de comunes y baldíos en 1618 y con la de hidalguías en $1630^{100}$.

Del mismo modo, la petición continua de soldados desde 1631 a 1663 va a ser motivo de fuertes resistencias y fricciones con la Corona, tal como expresan las Actas. Siempre se utiliza el mismo argumento «la cortedad de la tierra y pobreza della» y se pide una rebaja e, incluso, se les exima de esta carga.

En 1632 el gobernador del Principado apremia a los concejos a repartir 6.000 ducados para el sueldo de cien soldados y llega a presionar a los diputados de la Junta amenazándoles con que, si no lo conceden, cobraría de sus bienes $^{101}$. En 1634 la petición es de 300 infantes armados a costa del Principado; la Junta ofrece 200 y advierte que «no se aya de pedir mas numero dellos ni otra cossa ni por raçon de obligacion o contrato en que el Prinzipado este obligado ni por otra caussa ni accidente que suzeda».

Argumenta la imposibilidad de dar más «por la flaqueza a que se a reduçido toda la sustançia del Principado por la mucha que se a sacado del ultimamente»; también aduce la escasa cosecha de 1633 que originó pobreza y emigración ${ }^{102}$. Igualmente en 1636 los procuradores de la ciudad de Oviedo expresan muy bien las dificultades para pagar y el malestar ante la presión fiscal existente:

«El Prencipado se alla en tanto aprieto y necesidad de dineros con los servicios y donativo que de siete años a esta parte an hecho a su Magestad que ynportan mas de cien mil ducados y tiene de pagar el ultimo donativo ... y con los servicios de millones, bulas y alcabalas y otros tributos sera caso ynpusible poder acudir a la paga de todo por no tener propios ni arbitrios considerables ni otra cosa de que sacar dineros» 103 .

${ }^{99}$ Actas de las Juntas y Diputaciones del Principado de Asturias, transcripción de V.ELASCO, M.L. y Floriano, C., Oviedo, 1949-1964, t. II (1606-1622), pp. 35, 57, 63 y 82-83 (sesiones de 15-91609, 16-4-1611, 19-4-1611 y 3-1-1613).

${ }_{100}$ Actas ..., t. II, op. cit., pp. 216-237 (sesión de 24-10-1618) y t. III (1623-1636), pp. 133137 (sesiones de 21-6-1630 y 22-6-1630). En estas últimas reuniones se dice que el Reino para «ayuda de los grandes gastos que se le ofrecen a S.M. para la defensa de la Religión Catholica», permitió vender cien hidalguías de las que dos correspondían al Principado; algunos diputados, para evitar las ventas, proponen pagar al rey los 4.000 ducados que valía cada una de ellas, aunque finalmente se decide ofrecer 2.000 ducados en total.

${ }^{101}$ Actas ..., op. cit., t. III, pp. 151-158 y 171-176 (sesiones de 16-12-1631 y 5-4-1632).

${ }_{102}$ Actas ..., op. cit., t. III, pp. 196-201 (sesión de 6-4-1634).

${ }_{103}$ Actas ..., op. cit., t. III, pp. 276-277 (sesión de 14-3-1636)

Hispania, LXIII/1, núm. 213 (2003) 75-136 
Nuevamente se aduce la pobreza del Principado en 1643 y 1645 tras la levas solicitadas. En esta última fecha, ante la petición real de aumentar el servicio de 200 a 500 hombres con destino a la guerra de Cataluña, se dice que «la tierra se alla falta de jente por las nezesidades, ambres y muertes que a abido en este Prinzipado, con que se haçe inpusible el cunplimiento de la dicha Real Cedula» ${ }^{104}$. Con el mismo objetivo militar, en 1646 le corresponden al Principado 7.940 ducados; al año siguiente nuevamente la Corona pide 500 soldados, en 1648 solicita 300, en 1649 se le reparten 250 , en 1651 son 244 y en 1652 se suben a 300 . Aunque las quejas son continuas, en este último año la tensión sube de tono:

«no se trate de la conçesion de soldados por la estrecheza y pobreça con que se allan los vecinos deste Principado ... si se continua mucho las dichas levas y no ay reformacion en los exçesos dellos sera causa para despoblarse el Principado»105.

Aún en 1672 el diputado de Oviedo aduce «los grandes aprietos en que se halla por los continuos y considerables servicios que a hecho en todas ocasiones abentaxando en ellos a sus cortas fuerzas» y la Junta suplica nuevamente la exención de milicias ${ }^{106}$.

Igualmente fue larga y continua la oposición a la venta de oficios. Ya en 1597 pidió la Junta que no se vendiesen las alcaidías de cárceles, aunque en 1598 se desentiende de contribuir al consumo de las de Gijón y Siero y dice que las pagasen estos concejos "por ser en pro y aumento suyo». No obstante, en 1600 ante la posible venta de la alcaidía de la fortaleza y cárcel del Principado propone contradecirla y comprarla por el tanto, aduciendo. «los muchos daños e ynconbenientes que de tenerla un particular redunda, especial siendo natural desta tierra, a Su Magestad y a la administración de la justicia como a toda la republica» ${ }^{107}$.

Nuevamente vuelve a tratarse en 1629 lo perjudicial de la privatización de esta alcaidía, comprada por la familia Heredia en 1614; algunos concejos aducen «las grandes molestias y extorsiones que todos los naturales del $<$ Principado > padecen» y proponen consumir el oficio, pero finalmente la Junta no va a tomar la decisión.

La reunión de 8 de julio de 1615 la Junta comenta la actuación de García de Arreondo, juez encargado de la venta de oficios por el Consejo de Hacienda, y la de 16 de mayo de 1616 considera que oficios como alcaidías, almotacenes, corredurías y otros, «atento que no se usaban en este Principado», no deberían

\footnotetext{
${ }^{104}$ Actas ..., op. cit., t. IV, pp. 26-27 y t. V, pp. 90-91 y 95-98 (sesiones de 14-3-1643, 5-41645 y $12-4-1645)$

${ }_{105}$ Actas ..., op. cit., t. VII, p. 21 (sesión de 14-5-1652).

106 Actas ..., op. cit., t. VII, pp. 223-226 (sesión de 23-1-1671).

107 Actas ..., t. I (1594-1605), pp. 119 y 155 (sesiones de $25-7-1598$ y 9-3-1600 y t. III, p. 123 (sesión de 5-8-1629).
}

Hispania, LXIII/1, núm. 213 (2003) 75-136 
venderse ${ }^{108}$. En la sesión de 24 de octubre de 1618 se trata de la venta de comunes, de la de oficios de capitanes de los concejos y puertos de ballenas y se debate si contradecir estas ventas, así como si seguir el pleito sobre la Merindad Mayor del Principado, cargo perpetuado en 1614 a D. Francisco de la Torre ${ }^{109}$. En 1620 se denota en la Junta el gran malestar que produce la venta de doce procuraciones de número, hecha a pesar de que ya anteriormente el Principado había consumido dieciséis y pagado por ellas 4.267 ducados. La Junta decide seguir pleito para tantear las procuradurías, cargos que anteriormente ella proveía cada trienio al igual que hacía con los de Procurador General y Diputados ${ }^{110}$.

En 1635 produce especial malestar la creación y venta de las varas de alguaciles mayores de los concejos, a los que se había dado importantes preeminencias. Duele sobre todo que se vendan, puesto que la Corona tras el servicio de 40.000 ducados había prometido no enajenar más oficios ni regalías; se decide presionar a los compradores para que renuncien, así como ir a la Corte a contradecir la venta de alguacilazgos y otros oficios ${ }^{111}$.

En 1643 se trata sobre el tanteo del Alferazgo Mayor del Principado, cargo con importantes preeminencias en la Junta General; igualmente sobre el del Alguacilazgo de Millones y armazón de ballenas. Tras largos debates se decidió pedir en Madrid el resumen de estos dos oficios. La ciudad de Oviedo llegó a proponer el tanteo de éstos y otros oficios vendidos (Receptor de Millones, Escribanía de Millones, Tesorería de Alcabalas, oficios de la Cruzada), aduciendo que el monto total no llegaba a 16.000 ducados, siendo que sus salarios subían a más de $40.000^{112}$. En 1645 y 1646 se vuelve a tratar el tanteo del Alferazgo Mayor, así como el de Procurador General (que tenía voto en la Junta y en la Diputación) y en 1647 se decide resumir la Contaduría de Millones ${ }^{113}$. El último oficio del que nos consta la decisión de tanteo (en 1671) es el de Juez Superintendente de fábricas, montes y plantíos, que había comprado en 1668 D. Domingo de Herrera de la Concha; habrá pleito con el comprador y con sus herederos posteriormente ${ }^{114}$.

\footnotetext{
${ }^{108}$ Actas..., op. cit., t. II, pp. 120 y 142.

${ }^{109}$ El pleito sobre este oficio va a ser largo; en 1630 por sentencia del Consejo Real la Junta consigue finalmente su supresión. También la ciudad se había implicado en él y había dado poder en 1627 para seguirlo. Actas ..., op. cit., t. II, pp. 216-237 y t. III, pp. 126-129 y A.M.O., Libro Maestro de Fueros, t. I, fol. 125 v.

110 Actas ..., op. cit., t. II, pp. 253 y ss. (sesión de 4-5-1620). Nuevamente el Principado consumirá procuradurías en 1637 , abonando 1.088 ducados

${ }_{111}$ Actas ..., op. cit., t. III, pp. 258-268 (sesiones de $14-5-1.635$ y $15-5-1635$ ).

112 Actas ..., op. cit., t. IV, pp. 44-45, 57-67, y 69-96 (sesiones de 24-4-1643, 14-5-1643, 16-51643 y $18-5-1643)$.

${ }_{113}$ Actas ..., op. cit., t. V, pp. 191-193 y t. VI, pp. 178-181 (sesiones de 8-7-1646 y 27-11647). El pleito sobre el Alferazgo fue fallado en contra del Principado en 1646 (posteriormente se volvió a litigar y se eternizó por la influencia de los Queipo de Llano en la Corte). En cambio, se consiguió el tanteo del Alguacilazgo; la ciudad pidió un censo de 4.000 ducados para satisfacer su precio a D. Diego de Valdés Sorribas.

114 Actas ..., op. cit., pp. 200-205 (sesiones de 17 y 18-3-1671).
} 
La ciudad de Oviedo asume desde el principio, ante la frecuente inhibición y tibieza de la Junta, la responsabilidad de oponerse a las operaciones realizadas por los Austrias con los oficios y se mueve con febril actividad para negociar soluciones en Madrid. La resistencia se centra en contradecir la venta y perpetuación de cargos que anteriormente proveía la ciudad, también el acrecentamiento y la creación de otros de nueva factura; negocian la supresión, y si esto no era posible, el consumo de los oficios. Las cantidades que para ello desembolsó la ciudad a lo largo de más de un siglo fueron muy importantes.

Ya en 1544 el cabildo municipal pide al príncipe Felipe que no se acreciente el número antiguo de regidores y escribanos. Recuerda que el aumento de los regimientos es

«en grande daño desta ciudad por ser la becindad poca e porque añadyendose mas regidores abria en este consystorio opyniones e discordyas en lo qual su magd. no seria servido ni esta ciudad y su republica bien gobernada»115.

En 1570, ante la inminente venta de los oficios de fieles ejecutores, Oviedo va en dos ocasiones ante el Consejo de Hacienda aduciendo el daño y que «especialmente los pobres seran muy bejados y molestados». Expresa la escasa vecindad de la ciudad (300 vecinos) y el excesivo número de regidores ya existentes, así como que el aprecio de los mantenimientos no era función de los dos fieles que había sino de los regidores ${ }^{116}$. Finalmente en 1573 la ciudad de Oviedo decide redimir los dos fielazgos de la ciudad, ya vendidos a Pedro y a Juan de Argüelles, pagando los 1.600 ducados que les habían costado. Justifican su pretensión diciendo que, dadas las preeminencias que se da a estos fieles;

«siendo como la tierra es tan pobre y la gente tan poco hacendada ... se despoblara mucha parte della porque antes querran los vezinos dexar sus bienes e tratos e salirse della que no ser opremidos de ningun particular y zesando los tratos zesan las alcabalas de su magestad y la nobleza y poblacion» ${ }^{117}$.

115 A.M.O., Libro de Acuerdos 1541-1550.

116 Dice que hasta ese momento los fieles sólo son porteros en el ayuntamiento y llaman a los emplazados ante la justicia. La venta de fieldades va a crear conflictos y ser muy contestada en todas partes, ya que quitaba atribuciones a los regidores, especialmente las posturas en los mantenimientos y los derechos que sobre ellos llevaban. El consumo o tanteo de las fieldades, al igual que las procuradurías de número, va a ser general. A.G.S., C.J.H., lg. 105, fols. 5-7.

117 Los pone en cabeza de los regidores Rodrigo Bernardo de Miranda y licenciado Cifuentes. Para poder pagar solicita se le dé licencia para echar en sisa y hacer repartimiento entre los vecinos en los tratos y comercio. A.G.S., C.C., lg. 23. Las personas nombradas para el cargo (del linaje de los Argüelles) fue uno de los motivo para la toma de esta decisión por algunos regidores rivales, como se deduce de uno de los argumentos utilizados: «seria como añadir rexidores en la ciudad y aumentar las diferencias parcialidades y divisiones que ya hay»; éstas, siguen diciendo, "tomarian nuevas fuerzas al introducir personas de otras parcialidades de las que hay en dicho reximiento». 
Ante la venta masiva de regimientos y escribanías la actividad desplegada para evitar los acrecentamientos fue especialmente importante a comienzos de los años ochenta. En 1581 la ciudad aduce su pobreza, acrecentada por los gastos que traía el resumen de los procuradores de número y de los fieles ejecutores y la compra de jurisdicciones eclesiásticas que acababa de realizar; ésta última ascendía nada menos que a 20.337 ducados. En 1583 recuerda al rey que, a pesar de que en la ciudad había una vecindad de 400 vecinos, disponía de veintidós regidores, lo que era un número excesivo; en 1584 nuevamente se queja aduciendo que para los 500 vecinos que había los regidores ya ascendían a veinticuatro (el número antiguo era de ocho) y alegan «la confusion que abria de tantos regidores y votos dentro del dho. Ayuntamiento" si la Corona aumentaba aún más el número de las regidurías. Igualmente las escribanías se habían acrecentado hasta catorce (anteriormente había solamente ocho escribanos de número); se recuerda a la Corona que, por costumbre inmemorial y por carta ejecutoria, las proveía la ciudad, tanto en caso de vacante como de renuncia, y en las de puridad otorgaba también el título y protesta de que no le respete estos derechos. Estas actividades de la ciudad van a conseguir que desde 1581 a 1587 - años de ventas masivas en Asturias - no se enajenen más regimientos y escribanías en Oviedo.

En estos años la ciudad estaba en pleito con D. Pedro Solís sobre el alferazgo mayor y, al mismo tiempo, se va a oponer a la venta de la alcaidía de la cárcel del Principado. Protesta diciendo que «no es justo que se de lugar a tantos daños e inconvinientes como resultaran"; 'una vez consumada la venta, pide que se revoque el título dado, mostrándose dispuesta a servir con lo que había costado. Mientras la ciudad considera que el alcaide sólo debería tener jurisdicción dentro de la cárcel y que debería proveerlo ella con las atribuciones tradicionales, el rey justifica que el frecuente trato injusto, bien de «rigor y aspereza», bien de «largueza y licencia» se solucionaba nombrando persona que lo ejerciera de modo vitalicio; asigna al alcaide un salario de 40 ducados anuales que debería pagar el Principado y le da jurisdicción dentro y fuera de la cárcel $^{118}$. El coste de todas estas actividades (comisionados enviados a la Corte ${ }^{119}$, pleitos, consumo de oficios, compra de jurisdicciones eclesiásticas) es alto para la ciudad, siendo que además eran años difíciles para el Principado desde el punto de vista económico ${ }^{120}$.

118 A.G.S., C.J.H., lg. 188, fol. 1 y A.M.O., C-10. Había dos cárceles en Oviedo: una la del merino para los presos de la ciudad (era la casa particular del merino) y otra la cárcel-fortaleza donde iban los presos hechos por el corregidor. Es ésta última la que se vende ahora.

119 Toribio de Ribera estuvo durante varios meses en Madrid en 1581, gastando durante su estancia 447 ducados; igualmente permaneció en 1584 un total de 163 días, subiendo a 395 ducados entre salario y costas. En 1583 el regidor Rodrigo Bernardo había gastado por los mismos conceptos 506 ducados.

${ }^{120}$ En 1590 los mercaderes y tratantes de paños de la ciudad pleitean en el Consejo Real contra la ciudad por las sisas que echó para la compra de jurisdicciones. A.M.O., C-10.

Hispania, LXIII/1, núm. 213 (2003) 75-136 
También en el siglo XVII la ciudad de Oviedo va a luchar contra las ventas de oficios a través de pleitos, tanteos y consumos. La perpetuación de la $\mathrm{Me}-$ rindad Mayor del Principado en 1614, no sólo preocupó a la Junta sino también al cabildo municipal. En ese mismo año el rey privatizó la Merindad de la ciudad, despachando título de alcaide de la cárcel, pero la ciudad se avino con su comprador, D. Alonso de Solares ${ }^{121}$.

Nuevamente la ciudad va a ofrecer una fuerte resistencia ante el incremento de la venta de oficios en los años treinta; la repugnancia a que algunos cargos estén en manos de particulares es fruto de una larga y dolorosa experiencia. Así en 1637 va a Madrid a pedir el tanteo de la Alcaidía Mayor de Oviedo, comprada por Pedro de Leiguarda con voz y voto en el ayuntamiento; al mismo tiempo va a pleitear por el Alguacilazgo Mayor de Oviedo, adquirido por D. Sebastián Bernaldo de Quirós ${ }^{122}$. La venta del oficio de Contador de Millones a D. Fernando de Valdés, residente en Corte, va a crear un hondo malestar; algunos regidores dicen en 1639, que «a su magd. no le consta de los daños que resultan del usso y el ejercicio del» $y$ proponen su consumo ya que

«no es mas que vender en cierta forma todo este Principado y ponerle en la subjecion y dominio del particular que pretende comprarle que es zierto que con la mano que con el habra de tener y el dinero que abra de llebar por ser la jente con quien a de tratar lo mas dello pobre y miserable, lo uno los tuviera a todos subjetos y lo otro acabara de istinguir las pocas fuerças con que a quedado este Prindo de los servicios hechos por los derechos que ha de llebar y la libertad con que es çierto a de proceder en ellos»'123.

Accediendo a una petición de las Cortes, una real cédula de 17 de junio de 1647 suprimió las plazas de Contadores de Millones por ser los más dañosos de los que se habían vendido, pero la indemnización a los compradores debía ser a cargo de las ciudades ${ }^{124}$.

La ciudad va a seguir intentando en los años cuarenta y cincuenta consumir cargos enajenados por la Corona; en 1645 se debate, con división en el cabildo municipal, sobre la posibilidad de tantear o resumir los oficios de Escribano de la Gobernación y Procurador General en la Junta del Principado que estaban

121 En 1627 se compromete a pagarle por ella 2.800 ducados. No obstante, este cargo se va a volver a vender definitivamente a la casa de Heredia. A.M.O., Libro Maestro de Fueros, t. I, fol. 125. Sabemos que en 1614 también se consume una escribanía y se paga por ella 900 ducados a Alonso de Heredia. A.M.O., Libro de Acuerdos, 1614-1619.

${ }^{122}$ La ciudad dio poder para este pleito con el Alguacil Mayor, siendo que además éste pretendía nombrar un juez o alguacil de vagamundos. A.M.O., Libro Maestro de Fueros, t. I, fol. 102 v.

123 Son palabras del regidor D. Antonio de Heredia, al que apoyan Toribio de Rivera, Juan de Valdés Prada y D. Martín Menéndez de Avilés, entre otros. A.M.O., Libro de Acuerdos 1637 a 1640, fols. 362-364.

124 No obstante, en 1657 aún se pagaba el salario de Contador a D. Fernando de Valdés. A.M.O., Libro Maestro de Fueros, t. I, fol. $101 \mathrm{v}$.

Hispania, LXIII/1, núm. 213 (2003) 75-136 
vendidos a particulares en 8.500 ducados, así como el cargo de montero mayor de la ciudad. La decisión fue tantear éste último y que fuera la Junta General la que tomara postura sobre los otros dos ${ }^{125}$. Aparte del tanteo del Alguacilazgo Mayor de Millones para el que la ciudad pidió un censo de 4.000 ducados, va a pleitear con D. Francisco Javier Balbín y finalmente consigue en 1646 tantear la Escribanía de Millones, satisfaciendo los 1.450 ducados que le había costado ${ }^{126}$. Igualmente va a pagar para resumir la calidad que muchos regidores habían comprado desde 1636 de tener derecho a poner teniente que ejerciera el cargo ${ }^{127}$.

No sólo la ciudad de Oviedo sino otros concejos tratan de evitar la compra de oficios desde un principio. Así nos consta hizo el concejo de Siero en los años sesenta del siglo XVI; tras la concesión real en 1562 de título de regidor a Hernando de Somonte, residente en Corte y criado del rey, el ayuntamiento se opone a darle la posesión; se argumenta que en este concejo siempre hubo ocho regimientos y que se acababan de acrecentar otros seis (además del alferazgo), cifra excesiva para los 812 vecinos que tenía y que, dada la escasez de propios, recaería su salario sobre los pobres, los cuales «seran cada dia mas tributarios y mas fatigados» ${ }^{128}$.

Tras la perpetuación de las regidurías en los años sesenta y setenta, los vecinos de Siero expresan su malestar al rey diciendo que «andavan mal gobernados y los vecinos del muy vejados y molestados a causa de que los rexidores del dho. concejo heran perpetuos»; por ello le piden poder elegir cada año un procurador del común «que mirase y procurase lo que a la republica del dho. concejo conbeniese». Ante esta petición, el rey manda en 1577 al corregidor que vaya a Siero y en concejo abierto se informe sobre si había o no consentimiento de todos los vecinos para ello, así como si había habido anteriormente este cargo, cómo podría ser elegido y sobre la utilidad o daño que podría traer su creación ${ }^{129}$.

También en los años noventa fueron contestadas varias ventas hechas por el rey. Considera el concejo que la alcaidía de la cárcel, comprada por Gonzalo Argüelles de Celles en 1596, traería «muchas molestias y bejaciones», que co-

${ }_{125}$ A.M.O., Libro de Acuerdos 1644-1645, fols. 599-606.

126 A.M.O., Libro Maestro de Fueros, t. I, fol. 120.

${ }_{127}$ Nos consta que pagó por las tenencias 1.874 ducados en 1654 y 1.524 en fechas posteriores. A.M.O., Libro Maestro de Fueros, t. I, fols. 107-108. En 1642 el rey había apremiado a la ciudad para que diera posesión al regidor Toribio de Árgüelles, que había pagado 100 ducados por la facultad de poder poner teniente; aquélla se había negado aduciendo que ello significaría multiplicar aún más el número de regidores (ya había treinta y siete). A.U.O., casa Argüelles, caja 47.

${ }_{128}$ Alonso de Huergo, en nombre del comprador, critica la desobediencia al mandato del rey como «incierta y frivola y por persuasion» de personas que usan el oficio de regidores a través de otros, siendo que algunos tienen los oficios «encoraçados por otras personas que entran en el dho. ayuntamiento sin ser vzs. ni casados». Considera que, aparte de que no se llamó a concejo pleno, Hernando de Somonte es persona adecuada para el cargo, ya que es principal del concejo, con casa, hacienda y jurisdicción de gran valor (era nieto de García Menéndez de Valdés, señor del coto de Marcenado). A.U.O., Casa de Argüelles, caja 47.

129 A.U.O., Casa Argüelles, caja 47. 
metería abusos y que «por ser persona de mucha potencia» y los jueces «hombres aldeanos» no obedecería sus mandatos. Pide se le conceda consumir el oficio pagando al comprador lo que le costó; para ello, también solicita poder echar sisa en los mantenimientos, ya que un repartimiento sería más perjudicial dada la pobreza de los vecinos ${ }^{130}$. Ese mismo año los vecinos vuelven a insistir al rey que «ay muchos regidores y que despues que los mando perpetuar son los vecinos della muy vejados y molestados», por lo que piden que se consuman estos oficios dándoles arbitrios para poderlos pagar.

Igualmente la lucha por el control de los cargos concejiles entre los Vigil y los Argüelles hace que en 1596 éstos últimos encabecen la oposición a la creación de una tercera escribanía de puridad en el concejo, que había sido concedida a Jácome de Vigil. Aparte del excesivo número de escribanías que ya había en Siero (trece de número y tres de puridad para 800 vecinos), Gabriel de Argüelles argumenta que el nuevo escribano es un hombre poderoso que sustenta bandos en el concejo, con muchos parientes y amigos en el ayuntamiento. Finalmente el rey acepta que se consuma dicho oficio.

Del mismo modo, años después (en 1604), unos 200 vecinos del concejo de Nava intentan el consumo de todos los oficios pagando a sus propietarios lo que les había costado (había diez regimientos, un alferazgo y dos escribanías de ayuntamiento). Aducen que los jueces y regidores eran hombres ricos y poderosos de fuera del concejo, los cuales «hazian muchos agrabios y bexaciones tiniendo los officios en cabeza de criados hombres miserables sin atender al bien publico sino solo a sus pasiones y particulares intereses». Pero otros vecinos contradicen el consumo de cargos (movidos -según sus contrarios- por algunos interesados en ello); aducen que hay en el concejo 626 vecinos y, por tanto, más de los permitidos para poder resumir los oficios ${ }^{131}$.

\section{A MODO DE CONCLUSIÓN}

La demanda de oficios fue importante, ya que su posesión resultaba rentable para los compradores. Algunos cargos tenían un salario nada despreciable, pero sobre todo los privilegios, el prestigio, la influencia y el poder que aportaba el cargo era de diversos modos la antesala de beneficios económicos y favorecía el ascenso social (decidir en los asuntos económicos del municipio a su favor, posibilidad de hacerse oír en la Junta General, enlaces matrimoniales ventajosos, etc. ).

130 Se queja de que prevalecerá su interés particular y, sobre todo, llevará muchos derechos a los presos (frente a los 6 mrs. que pagaban hasta ahora); también de que no los dejará salir por venderles allí los mantenimientos, cosa que no sucedía hasta ahora, ya que el alcaide era puesto por la justicia y regimiento. A.U.O., Casa de Argüelles, caja 47.

131 La otra parte decía que no eran más de 310 , con lo cual podían acogerse al consumo permitido a los núcleos de población de menos de 500 vecinos. A.U.O., Casa de Argüelles, caja 47. 
A pesar de los tanteos y consumos en algunos municipios se produjo una saturación de cargos que, en gran medida, va a traer un desprestigio y un perjuicio para los demás ${ }^{132}$. Especialmente en el caso de los escribanos, sus ingresos dependían del número de competidores que tuvieran y lógicamente el acrecentamiento de oficios les perjudicó de modo importante y se degradó mucho su profesión ${ }^{133}$.

La venta de oficios trae la inversión en rentas fijas, en bienes improductivos, llegando a ser preferida — vista como más lucrativa - la compra de cargos a la de censos y juros. Un oficio generaba una renta, servía de medio de pago y podía darse en dote y transmitirse en herencia ${ }^{134}$. Pero desde el punto de vista del interés general, inmoviliza capitales que podían haber sido mejor empleados, no se crea riqueza. El mismo efecto produce la compra de alcabalas y de jurisdicciones que también van a realizar algunas casas nobles asturianas ${ }^{135}$. En el mismo sentido hay que interpretar la frecuencia del gasto en mantener o mejorar su status, tales como la adquisición de hábitos o títulos, así como otros gastos improductivos tendentes al lujo y la ostentación.

También la venta de oficios va a ser un buen negocio para la Monarquía. La importante cantidad de dinero recaudada por esta vía (unos 300.000 ducados) va a servir para paliar los agobios financieros de los Austrias y ayudarles a mantener su política hegemónica, siendo que, además, a diferencia de otros arbitrios utilizados, no tiene contrapartidas económicas a medio o a largo plazo. Al contrario, debemos tener en cuenta el dinero que la Corona va a ingresar posteriormente por provisión de oficios vacos, por consumos y por derechos sobre transmisiones.

132 En 1678 se plantea en la Junta General el consumo de oficios de regimiento de la ciudad de Oviedo porque era excesivo su número para una población que no pasaba de 2.000 vecinos: había 61 (de los que 30 eran antiguos y 31 creados posteriormente a 1630). Además muchos regidores habían comprado el derecho a poner teniente. Junta de 1-6-1678. MENÉNDEZ, A.: «La venta de oficios públicos ...», art. cit., p. 702.

${ }_{133}$ A fines del s. XVII, según datos de A. Menéndez, en 30 concejos que contaban con regimientos perpetuos (cuya vecindad ascendía a 27.942 vecinos) había un total de 264 escribanías de número; de esta estimación se deduce que a cada escribano le correspondían una media de 105,8 vecinos. MENÉnDEZ, A.: «La venta de oficios públicos ...», art. cit., p. 707. Solamente la ciudad de Oviedo cuenta a fines del XVII con veintinueve escribanías (trece anteriores a 1640 y dieciseis posteriores a esta fecha). SANGRADOR, M.: Historia de la administración de justicia y del antiguo gobierno del Principado de Asturias, Oviedo, 1866, p. 152.

${ }_{134}$ En este sentido, va ser objeto de numerosos pleitos entre herederos.

135 En el siglo XVII compran las alcabalas de algunos concejos asturianos D. Pedro Menéndez de Avilés, D. Benito Trelles, D. Gabriel Flórez Osorio, D. Antonio de Heredia, D. Fernando Queipo de Llano, D. Pedro Fernández Leiguarda, D. Antonio de Estrada y D. Baltasar de Ribera Prada. Tras la venta de jurisdicciones eclesiásticas, iniciada por Felipe II a comienzos de los años ochenta, igualmente intentaron comprar un señorío muchas casa nobles, aunque finalmente esta intención quedó abortada con la redención casi general de los pueblos. Finalmente sólo compraron un coto Rodrigo Bernardo de Miranda, Gonzalo Ruiz de Junco y Diego García de Tineo; el monto del pago a la Corona ascendió en conjunto a 5.470 ducados. 
Sin embargo, las consecuencias para los municipios van a ser muy negativas; este expediente va a influir de modo directo en su endeudamiento. Por un lado, aumenta el gasto público al tener que mantener tantos oficios; además pleitos, tanteos, consumos, costas en pagos de comisionados a la Corte y abogados son detracciones importantes para las arcas de los concejos, que están en la base de la decadencia de la institución municipal y, especialmente, del declive de las ciudades y grandes villas de la Corona castellana ${ }^{136}$. Éstas, al contrario de lo que sucedió, tendrían que haber sido un puntal básico para el desarrollo económico y social. No podemos despreciar el coste social, ya que evitar los graves daños de la venta de oficios se traduce, en última instancia, en imponer sisas o tomar censos, que debía soportar, al mismo tiempo que otras muchas cargas e impuestos, el conjunto de la sociedad.

La venalidad de oficios, al igual que el resto de los arbitrios utilizados por los Austrias y, en general, la excesiva fiscalidad directa e indirecta a que estuvo sometida la población asturiana en los siglos XVI y XVII fue realmente nefasta para la economía del Principado y para la mayor parte de la población ${ }^{137}$.

Las repercusiones políticas de la venalidad de cargos municipales fueron importantes, ya que a nivel municipal se decidían muchas cuestiones; los intereses públicos, al quedar a expensas de unas pocas familias, van a quedar muy perjudicados. La participación de la comunidad en la vida municipal que permitían los cargos electivos queda definitivamente anulada por completo y la posibilidad de confrontación, de oposición y, en definitiva, de defensa de los intereses generales suprimida. Unido a la venta de cargos tiene lugar un proceso de patrimonialización de lo público y de oligarquización de la vida municipal. Se forman cuerpos cerrados de regidores, base para el abuso y la corrupción.

No debemos olvidar que la provisión y venta de oficios da al rey un patronazgo directo sobre los nuevos cargos. Pero, al mismo tiempo, se produce una dignificación de la minoría dirigente a nivel local que, en definitiva, trae una identidad de intereses con la Corona. Al menos, no hay una confrontación con la política seguida por los Austrias y la oposición fue puntual y débil, especialmente por lo que se refiere a la Junta General del Principado. También tiene lugar una definición y una clarificación del grupo social dominante, el cual se va distanciando cada vez más del cuerpo social y afirmando unos valores y, sobre todo, un comportamiento económico muy negativos para la evolución económica del Principado.

Además, como muy bien observa Domínguez Ortiz, el que hubiera muchos propietarios de cargos absentistas y que los servían con sustitutos hace que la

\footnotetext{
136 Otros arbitrios aplicados por los Austrias tienen parecidos efectos. La ciudad de Oviedo compra un concejo y cinco cotos eclesiásticos por los que debe asumir el pago de 20.337 ducados. Ya dijimos como en 1590 los mercaderes y tratantes de paños entablaron pleito contra la ciudad ante el Consejo Real por la sisa puesta para el pago de la cantidad citada.

137 Sólo por vía de venta de jurisdicciones eclesiásticas van a salir de Asturias en los años ochenta del siglo XVI un total de 210.746 ducados.
} 
degradación del municipio como órgano representativo sea aún más completa $^{138}$. En este sentido, tampoco hay que olvidar que muchas competencias de los municipios (especialmente en cuanto a provisión de cargos) quedan mermados, en manos de la Corona y de los propietarios de los cargos. Estos últimos a lo largo del tiempo de utilización de este arbitrio van a verse sometidos a un proceso de selección, de tal modo que las élites locales van a ser sustituidas poco a poco en muchos concejos por las principales familias del Principado, algunos de cuyos miembros viven en la ciudad e incluso en la Corte. Los municipios van a verse así subordinados a los intereses de esa élite provincial, en detrimento de los intereses de los pueblos e, incluso de las élites locales. El tráfico de oficios va a permitir la acumulación de cargos de los diversos concejos en algunas familias, que extienden su poder a amplias zonas de Asturias, el cual utilizan para la defensa de sus particulares intereses económicos.

138 Domínguez ORTIZ, A.: «La venta de cargos...», art. cit., p. 135.

Abreviaturas: A.G.H. (Academia de Genealogía y Heráldica); A.G.S. (Archivo General de Simancas); A.M.O. (Archivo Municipal de Oviedo); C.C. (Cámara de Castilla); C.J.H. (Consejo y Juntas de Hacienda); D.G.T. (Dirección General del Tesoro).

Hispania, LXIII/1, núm. 213 (2003) 75-136 


\section{CUADRO 2. REGIMIENTOS VENDIDOS EN ASTURIAS DURANTE LOS SIGLOS XVI Y XVII}

\begin{tabular}{|c|c|c|c|}
\hline AÑO & CONCEJO & COMPRADOR & $\begin{array}{l}\text { PRECIO } \\
\text { (DUCADOS) }\end{array}$ \\
\hline \multirow[t]{7}{*}{1544} & Oviedo & $\begin{array}{l}\text { Luis González de Oviedo, Alonso González de la } \\
\text { Rúa, Andrés de Prada, Licdo. Alonso Ramírez, } \\
\text { Juan de Carrio, Licdo. Guimaran, Antonio Carreño } \\
\text { y Juan de Argüelles } \\
\end{array}$ & $(8 x) 150$ \\
\hline & Avilés & $\begin{array}{l}\text { Pedro de León, Luis Alonso de León, Pedro de } \\
\text { Valdés, Menen Pérez de Valdés, Juan Cuervo, } \\
\text { Pedro Esteban de las Alas, Gonzalo de Grado, } \\
\text { Hernando de las Alas y García de Torres }\end{array}$ & $(9 x) 150$ \\
\hline & Gijón & $\begin{array}{l}\text { Juan de Llanos, Juan Morán de Lavandera el viejo, } \\
\text { Juan de Valdés, Bartolomé González de Cornella- } \\
\text { na, Fabián García Jove, Diego González de Llanos, } \\
\text { Diego de Valdés y Gonzalo de Tineo } \\
\end{array}$ & $(8 \mathrm{x}) 120$ \\
\hline & Colunga & $\begin{array}{l}\text { Gonzalo Ruiz de Junco, Alvaro Díaz de Nava, } \\
\text { Hernando de Covián de Pobladura, Gonzalo de } \\
\text { Rivero, Diego de Vega, Rui Sánchez }\end{array}$ & $(6 x) 100$ \\
\hline & Villaviciosa & $\begin{array}{l}\text { Bernardino de Busto, Diego de Valdés Miruega, } \\
\text { Gutierre de Hevia, Pedro Díaz de Peón, Hernán } \\
\text { García de la Pinilla, Min Montes, Hernando de } \\
\text { Valdés, Diego de Valdés y Gonzalo de Hevia } \\
\end{array}$ & $(9 x) 110$ \\
\hline & Pravia & $\begin{array}{l}\text { Garci González Barbón, Lope de Omaña, Hernan- } \\
\text { do de Miranda, Gutierre González Cienfuegos, } \\
\text { Alvaro Peláez, Juan Núñez de Avilés, Gómez Arias } \\
\text { y Hernando de Arango }\end{array}$ & $(8 x) 110$ \\
\hline & Gozón & $\begin{array}{l}\text { Marcos de Verdasquera, Juan García del Herrero, } \\
\text { Rui González de la Pola de Avengo y Hernando de } \\
\text { Bango }\end{array}$ & $(4 x) 100$ \\
\hline \multirow[t]{2}{*}{1545} & Avilés & Diego Pacheco y Francisco de Pareja & $(2 x) 150$ \\
\hline & Gozón & Esteban de la Vega y Alonso González de la Reguera & $(2 \mathrm{x}) 100$ \\
\hline \multirow[t]{2}{*}{1546} & Avilés & $\begin{array}{l}\text { Doctor Cristóbal de Viana y doctor Francisco de la } \\
\text { Fuente }\end{array}$ & $(2 x) 120$ \\
\hline & Colunga & Rodrigo de Junco y Sancho de Estrada & $(2 x) 100$ \\
\hline \multirow[t]{4}{*}{1549} & Avilés & Alonso de Carreño y Juan Bernaldo de Quirós & $(2 \mathrm{x}) 150$ \\
\hline & Gijón & Juan de Mieres y Pedro de Llanos & $(2 x) 120$ \\
\hline & Oviedo & Capitán Lope de Estrada y bachiller Min de Valdés & $(2 x) 200$ \\
\hline & Villaviciosa & Julián García del Busto y Rodrigo de Hevia & $(2 x) 110$ \\
\hline 1557 & Avilés & $\begin{array}{l}\text { Pedro Menéndez de Avilés, Alvar Sánchez de Avi- } \\
\text { lés, Juan de Paredes, Bartolomé de León, Alonso } \\
\text { Carreño el mozo y Diego de Valdés y Simón de } \\
\text { León }\end{array}$ & $(6 x) 200$ \\
\hline
\end{tabular}




\begin{tabular}{|c|c|c|c|}
\hline AÑ & CONCEJO & COMPRADOR & $\begin{array}{c}\text { PRECIO } \\
\text { (DUCADOS) }\end{array}$ \\
\hline \multirow[t]{3}{*}{1557} & Gijón & Alonso Ramírez & 180 \\
\hline & Gozón & Sin datos (dos) & $(2 x) 100$ \\
\hline & Oviedo & $\begin{array}{l}\text { Alonso de la Ribera, Diego González de la Rúa, } \\
\text { Diego Carreño, Francisco Carreño, Gaspar de Avi- } \\
\text { lés, Pedro de Carrio, lcdo. Rodrigo de Miranda, } \\
\text { Pedro Menéndez de Oviedo, D. Pedro de Solís y } \\
\text { Menendo de Marines }\end{array}$ & $(10 x) 200$ \\
\hline \multirow[t]{2}{*}{1558} & Gijón & Gregorio García de Jove & 180 \\
\hline & Oviedo & Gaspar de Avilés & 300 \\
\hline 1560 & Oviedo & Licdo. Juan de Nora & 300 \\
\hline 1561 & Gozón & Pedro de Prendes & 150 \\
\hline \multirow[t]{9}{*}{$\begin{array}{l}1562- \\
1563^{*}\end{array}$} & Aller & $\begin{array}{l}\text { Francisco Bernaldo, Sancho Ordóñez, Diego Solís, } \\
\text { Juan Castañón, Miguel Ordóñez de Caborana, } \\
\text { Miguel Bernaldo, Fabián Ordoñez y Juan de Robles }\end{array}$ & $(8 x) 66$ \\
\hline & Cabranes & $\begin{array}{l}\text { Gutierre de Hevia, Pedro de Escobedo, Fernán } \\
\text { García de la Pinilla, Gonzalo de los Corrales el viejo } \\
\text { y Juan del Llagar }\end{array}$ & $(5 x) 40$ \\
\hline & Cangas de Onís & $\begin{array}{l}\text { Fernán Suárez de Labra, Juan de Soto, Alonso } \\
\text { Fernández del Cueto, Diego Fernández de Labra, } \\
\text { Gutierre Alonso de Intriago y Juan del Cueto de } \\
\text { Margolles }\end{array}$ & $(6 x) 40$ \\
\hline & Caravia & $\begin{array}{l}\text { Gonzalo de Suero Díaz, Juan de Rui Gutierrez, } \\
\text { Juan de Cofiño y Alonso del Valle }\end{array}$ & $(4 x) 40$ \\
\hline & Carreño & $\begin{array}{l}\text { Benito Carreño, Pedro de Prendes, Alvaro Carreño } \\
\text { de Avilés, Pedro Díez de Valdés, Melchor de Val- } \\
\text { dés de Candás, Alonso de Carreño el mozo, Pedro } \\
\text { de Carrio y Rodrigo de Carreño }\end{array}$ & $(8 x) 64$ \\
\hline & Castrillón & $\begin{array}{l}\text { Pedro García del Cueplo, Juan Fernández del Cue- } \\
\text { to de Somió, Diego Fernández de Junco, Juan } \\
\text { Cuervo de Quirós y Juan Fernández de Vega de } \\
\text { Castrillón }\end{array}$ & $(5 x) 40$ \\
\hline & Corvera & $\begin{array}{l}\text { Boiso Suárez de Solís, Martín de Bango, Suero de } \\
\text { Bango, licenciado Solís, Pedro de León y Juan } \\
\text { Bernaldo de Quirós }\end{array}$ & $(5 x) 50$ \\
\hline & Laviana & $\begin{array}{l}\text { Pedro de Hevia, Nicolás de Hevia, Alonso Fernán- } \\
\text { dez de la Ferrera, Pedro Moniz de Nava, Juan } \\
\text { Moniz del Condado y Marcos Suárez de la Pola }\end{array}$ & $(6 x) 50$ \\
\hline & Lena & $\begin{array}{l}\text { Sebastián Bernaldo, Diego de Miranda, Gutierre de } \\
\text { Campomanes el viejo, Diego Alvárez de Ronzón, } \\
\text { Diego González de Quirós, Alonso de las Alas, } \\
\text { Gabriel Ordóñez, Juan de Argüelles de la Puente, } \\
\text { Juan de Campomanes de la Frecha y Rodrigo de } \\
\text { Hevia de Piedraceda }\end{array}$ & $(10 x) 80$ \\
\hline
\end{tabular}




\begin{tabular}{|c|c|c|c|}
\hline AÑO & CONCEJO & COMPRADOR & $\begin{array}{l}\text { PRECIO } \\
\text { (DUCADOS) }\end{array}$ \\
\hline \multirow[t]{6}{*}{$\begin{array}{l}1562- \\
1563 *\end{array}$} & Onís & $\begin{array}{l}\text { Pedro González de Teleña, Fernán García de Ce- } \\
\text { bos, Pedro Fernández de Labra, Sancho Díez de } \\
\text { Menes, Gómez de Quilana }\end{array}$ & $(5 x) 40$ \\
\hline & Parres & $\begin{array}{l}\text { Bernardo de Estrada, Pedro Sánchez Topete, Juan } \\
\text { de Cofiño de la Cuesta, Martín de Villar, Gonzalo } \\
\text { López de Pandiello y Pedro de Otero }\end{array}$ & $(6 x) 40$ \\
\hline & Piloña & $\begin{array}{l}\text { Fernando de Valdés el viejo, Juan de Caso, Gutierre } \\
\text { Bernaldo, Juan Alonso de la Piñera, Juan Moniz de } \\
\text { Lozana, Gabriel de Valdés, bachiller Junco y Pedro } \\
\text { de Alvaro Suarez }\end{array}$ & $(8 x) 66$ \\
\hline & Ribadesella & $\begin{array}{l}\text { Gonzalo Ruiz de Junco, Gonzalo Prieto, Alonso de } \\
\text { la Vega, Sancho de Estrada, Rodrigo de Junco el } \\
\text { mozo, Pedro de Labra y Juan Prieto }\end{array}$ & $(7 x) 58$ \\
\hline & Sariego & $\begin{array}{l}\text { Alonso de Caso, Gonzalo de Riva, Gonzalo de } \\
\text { Friera, Juan de Valvidares y licenciado Bueres }\end{array}$ & $(5 x) 40$ \\
\hline & Siero & $\begin{array}{l}\text { Juan de Vigil, Francisco de Vigil, Gonzalo de Ar- } \\
\text { güelles, el soldado, Rodrigo de Argüelles de Gran- } \\
\text { da, Diego de Argüelles de Palacio, Francisco de } \\
\text { Hevia, Pablo de Hevia, Urbano de Guergo, Mateo } \\
\text { de Agüera, Lope de Argüelles de Vega de Poja, } \\
\text { Alonso de Argüelles, Pedro Díaz del Coto (en con- } \\
\text { franza de } P^{\circ} \text { de Argüelles de Meres) y Hernando de } \\
\text { Somonte }\end{array}$ & $(13 x) 80$ \\
\hline \multirow[t]{3}{*}{1564} & Colunga & Alvaro Rodríguez Vitorero & 100 \\
\hline & Gijón & Alvaro de Llanos y Gonzalo García Jove & $(2 \mathrm{x}) 120$ \\
\hline & Pravia & Alonso de Inclán y Suero González de Inclán & $(2 x) 110$ \\
\hline 1565 & Pravia & Diego Menéndez de Acellana & 110 \\
\hline \multirow[t]{6}{*}{1566} & Aller & Sebastián Bernaldo de Quirós & 90 \\
\hline & Gijón & $\begin{array}{l}\text { Pedro Sánchez de Cifuentes y capitán Jordán de } \\
\text { Valdés }\end{array}$ & $(2 \mathrm{x}) 120$ \\
\hline & Oviedo & $\begin{array}{l}\text { Gabriel de Perlin (renuncia en } 1567 \text { en Fernando } \\
\text { Alvarez de Ribera) }\end{array}$ & 200 \\
\hline & Pravia & Martín de Quirós & 100 \\
\hline & Siero & Pedro de León & 130 \\
\hline & Villaviciosa & Pedro Sánchez de Peón & 110 \\
\hline \multirow[t]{3}{*}{1568} & Oviedo & Lcdo. Juan de Cifuentes & 200 \\
\hline & Villaviciosa & Jácome de Costales & 110 \\
\hline & Pravia & Gutierre Bernaldo & 110 \\
\hline 1569 & Pravia & Toribio Suárez de la Cuesta & 110 \\
\hline 1571 & Lena & Diego de Pantiga Hevia & 80 \\
\hline \multirow[t]{2}{*}{1572} & Avilés & Pedro del Busto & 146 \\
\hline & Corvera & Alonso de Calienes & 110 \\
\hline
\end{tabular}




\begin{tabular}{|c|c|c|c|}
\hline AÑO & CONCEJO & COMPRADOR & $\begin{array}{c}\text { PRECIO } \\
\text { (DUCADOS) }\end{array}$ \\
\hline \multirow[t]{2}{*}{. } & Pravia & Jácome González de Avilés & 80 \\
\hline & Siero & Diego Suárez & 130 \\
\hline \multirow[t]{3}{*}{1573} & Corvera & Antonio Vázquez de Quirós & 80 \\
\hline & Lena & Diego de la Ribera & 90 \\
\hline & Pravia & Alonso de Calienes & 110 \\
\hline 1574 & Lena & Hernando de Malleza & 80 \\
\hline 1581 & Oviedo & Alvaro de Salas & 300 \\
\hline \multirow{17}{*}{$\begin{array}{l}1583- \\
1584\end{array}$} & Aller & Martín de Robles del Pino, el mozo & 150 \\
\hline & Amieva & $\begin{array}{l}\text { Juan de Soto, Cosme García, Julián de Vega, Juan } \\
\text { García de Vega y Diego García de Cirieno }\end{array}$ & $(5 x) 101$ \\
\hline & Avilés & Alvaro de Carreño y Nicolás de Carreño & $(2 x) 300$ \\
\hline & Carreño & Luis de Valdés y Juan de Prendes & $(2 x) 200$ \\
\hline & Castrillón & $\begin{array}{l}\text { Nicolás de Llano de Ponte y Juan González de } \\
\text { Sandamies }\end{array}$ & $(2 \mathrm{x}) 100$ \\
\hline & Cabrales & $\begin{array}{l}\text { Pedro Díaz de Arenas el viejo, Pedro de Posada, } \\
\text { Diego de Posada, Gonzalo Pérez de Puerta, Gonza- } \\
\text { lo de Villar y Francisco García }\end{array}$ & $(6 x) 130$ \\
\hline & Cangas de Onís & $\begin{array}{l}\text { Pedro de Sobrecuevas, Pedro Sánchez de Intriago, } \\
\text { Juan de Villar de Margolles y Juan González de } \\
\text { Cabiellas }\end{array}$ & $(4 x) 250$ \\
\hline & Colunga & Juan Alonso de Covián & 130 \\
\hline & Gijón & $\begin{array}{l}\text { Juan de Cifuentes, Alonso Ramírez el mozo, Mi- } \\
\text { guel García Jove y Hernando de Valdés Bernardo }\end{array}$ & $(4 x) 320$ \\
\hline & Gozón & $\begin{array}{l}\text { Pedro Alvarez de Valdés y Diego de Valdés Váz- } \\
\text { quez }\end{array}$ & $(2 x) 221$ \\
\hline & Lena & Doctor Juan de Faes & 300 \\
\hline & Miranda & $\begin{array}{l}\text { Arias de Begega, el viejo, García de Begega. Arias } \\
\text { de Begega el mozo, Juan González de Leiguarda }\end{array}$ & $(4 x) 110$ \\
\hline & Nava & $\begin{array}{l}\text { Juan de Faes, Pedro Díaz de la Pola, Pedro Díaz } \\
\text { del Espineda, Lope de Nava, Juan de Nava y Alva- } \\
\text { ro de Nava }\end{array}$ & $(6 x) 110$ \\
\hline & Onís & Juan de Labra & 130 \\
\hline & Parres & $\begin{array}{l}\text { Juan de Estrada de Nevares y Pedro de Nava de } \\
\text { San Min }\end{array}$ & $(2 x) 130$ \\
\hline & Piloña & Alonso Osorio y Pedro de Valdés Estrada & $80+220$ \\
\hline & Ponga & $\begin{array}{l}\text { Juan Alonso de Barades el viejo, Juan Caso de Sorri- } \\
\text { bas, Pedro del Cueto de Tajanes y Alonso Osorio }\end{array}$ & $(4 \mathrm{x}) 80$ \\
\hline & Pravia & Nicolás de Llano de Ponte y García de Doriga & $(2 x) 195$ \\
\hline & Ribadesella & $\begin{array}{l}\text { Gonzalo Ruiz de Junco, Pedro Sánchez de Junco y } \\
\text { Gutierre Peláez }\end{array}$ & $(3 x) 220$ \\
\hline
\end{tabular}




\begin{tabular}{|c|c|c|c|}
\hline AÑO & CONCEJO & COMPRADOR & $\begin{array}{l}\text { PRECIO } \\
\text { (DUCADOS) }\end{array}$ \\
\hline \multirow[t]{6}{*}{$\begin{array}{l}1583- \\
1584\end{array}$} & Salas & $\begin{array}{l}\text { Hernando de Malleza, García de Doriga, Hernando } \\
\text { García de Doriga (hijo), Alvaro de Salas, Juan de } \\
\text { Marinas, Gonzalo de Malleza, Alvaro de Valdés y } \\
\text { Alonso de Francos }\end{array}$ & $(8 x) 150$ \\
\hline & Sariego & Fernán Suárez de Pedrosa y Bernabé de Vigil & $(2 x) 92$ \\
\hline & Siero & Doctor Juan de Faes & 300 \\
\hline & Tineo & $\begin{array}{l}\text { Lope de Miranda, García de Valdés, Juan Marcos } \\
\text { de Rojas, Juan Queipo de Tineo, Diego García del } \\
\text { Riego, Pedro Núñez de Tuña, Doctor Gonzalo } \\
\text { Solís de Meras, Alvaro García Caballero }\end{array}$ & (8x) 255 \\
\hline & Valdés & $\begin{array}{l}\text { Diego de Paredes, Alonso García, Juan García de } \\
\text { Paredes, Lope García de Canedo, licdo. Lope García } \\
\text { Avello, Gonzalo Fuertes de Sierra, Sancho Melén- } \\
\text { dez Avello, Pedro Rico de Luarca }\end{array}$ & $(8 x) 200$ \\
\hline & Villaviciosa & $\begin{array}{l}\text { Diego Montes Vigil, Sebastián Fernández de la } \\
\text { Espriella, Toribio de Valdés, Alonso Alvarez Sola- } \\
\text { res, Diego de Valdés }\end{array}$ & $(5 x) 300$ \\
\hline \multirow{5}{*}{$\begin{array}{l}1585- \\
1586\end{array}$} & Cabrales & Pedro Díaz de Arenas & 130 \\
\hline & Cangas de Tineo & Arias de Omaña y D. Arias de Omaña, hijo & $(2 x) 400$ \\
\hline & Llanes & $\begin{array}{l}\text { Toribio Alonso de Arenas, Gómez de Posada, Her- } \\
\text { nando de Posada y Juan González de Posada }\end{array}$ & $(4 x) 200$ \\
\hline & Salas & Rodrigo de Miranda de Linares & 150 \\
\hline & Siero & Diego de la Ribera & 300 \\
\hline \multirow{6}{*}{$\begin{array}{l}1587- \\
1588\end{array}$} & Aller & Juan de Robles del Pino, el mozo & 150 \\
\hline & Cangas de Tineo & $\begin{array}{l}\text { García de Valdés, Alonso de Llano, Juan Flórez de } \\
\text { Valdés, Juan Queipo de Llano, capitán Suero Queipo } \\
\text { de Llano, Suero Queipo de Llano el viejo, Luis Alon- } \\
\text { so de Bimeda, Alonso de Monco, Juan de Rojas de } \\
\text { Tineo, Diego García de Tineo, Juan de Tineo }\end{array}$ & $(11 x) 400$ \\
\hline & Caso & $\begin{array}{l}\text { Diego de Caso del Campo, Alvaro de Caso, Ber- } \\
\text { nardo de Caso, Gutierre Bernaldo de Caso, Alonso } \\
\text { de Caso de los Cobos y Suero de Caso }\end{array}$ & $(6 x) 133$ \\
\hline & Laviana & Juan de Robles & 100 \\
\hline & Llanes & $\begin{array}{l}\text { García González de la Madrid, D.Antonio de Es- } \\
\text { trada, Pedro de Posada de Mere, lcdo. Juan de } \\
\text { Barreda del Corro, Juan del Castillo, Juan de Posa- } \\
\text { da Turanzas, Fernando de Valdés Junco, Juan de } \\
\text { Mendoza de Andrín }\end{array}$ & (8x) 250 \\
\hline & Salas & $\begin{array}{l}\text { Sancho de Inclán, Pedro Longoria, Juan Avello y } \\
\text { Luis Fernández de Fogueiras }\end{array}$ & $(4 x) 200$ \\
\hline
\end{tabular}




\begin{tabular}{|c|c|c|c|}
\hline AÑO & CONCEJO & COMPRADOR & $\begin{array}{l}\text { PRECIO } \\
\text { (DUCADOS) }\end{array}$ \\
\hline \multirow{5}{*}{$\begin{array}{l}1587- \\
1588\end{array}$} & Onís & Pedro Gutierrez de Nevares & 150 \\
\hline & Oviedo & $\begin{array}{l}\text { Fernán Alvarez de la Ribera y Fernando Montes de } \\
\text { Vigil }\end{array}$ & $600+700$ \\
\hline & Siero & Diego Suárez de Meres & 375 \\
\hline & Somiedo & Diego Flórez de Valdés & 125 (est.) \\
\hline & Tineo & Gaspar Bernardo y Francisco Bernardo & $(2 x) 275$ \\
\hline \multirow[t]{5}{*}{$\begin{array}{l}1590- \\
1591\end{array}$} & Grado & $\begin{array}{l}\text { Fernando Alvarez de la Ribera el viejo, García de la } \\
\text { Ribera de Nores, Fernando Alvarez de la Ribera el } \\
\text { mozo, Toribio Alvarez de Nalón, Lope Fernández de } \\
\text { Panizal, Pedro de Canedo, Juan Arias de Tolinas, } \\
\text { Fernando de Miranda, Fernando Alvarez de Santia- } \\
\text { nes, Diego Alvarez de Motas, Alvaro Díez de San } \\
\text { Min, Gabriel Fernández de Santianes, Gonzalo de } \\
\text { Aldonza de Santianes, Alonso Martínez de Grado, } \\
\text { Fernando Alvarez el viejo, Gonzalo Arias de la Mota, } \\
\text { Min Fernández del Prado y Alonso González del Río }\end{array}$ & $(18 x) 500$ \\
\hline & Miranda & Pedro de Longoria y Diego de Canedo & $(2 \mathrm{x}) 200$ \\
\hline & Pravia & Tomás Bernardo de Miranda y Luis de Entrago & $(2 x) 400$ \\
\hline & Siero & Mateo de la Villa de Hevia & 400 \\
\hline & Somiedo & Pedro Bernaldo y Gabriel Sierra & $(2 x) 125$ \\
\hline \multirow[t]{3}{*}{$\begin{array}{l}1592- \\
1593\end{array}$} & Illas (Avilés) & $\begin{array}{l}\text { Juan Fernández de la Peral, Esteban González de } \\
\text { San Roman y Sebastián Velázquez }\end{array}$ & $(3 x) 83$ \\
\hline & Oviedo & Bernabé de Vigil & 900 \\
\hline & Sariego & Toribio Argüelles de Meres y Quiñones & 200 \\
\hline \multirow{6}{*}{$\begin{array}{l}1594- \\
1596\end{array}$} & Avilés & Pedro Menéndez de Avilés & 250 \\
\hline & Cangas de Tineo & Doctor Juan de Llanos Valdés & 400 \\
\hline & Laviana & Juan Mirón y Fabián Díaz del Acebal & $(2 x) 200$ \\
\hline & Lena & $\begin{array}{l}\text { Martín González de Cienfuegos, Sebastián Bernal- } \\
\text { do de Quirós y D. Baltasar de Cienfuegos, gentil- } \\
\text { hombre de la casa de SM }\end{array}$ & $\begin{array}{r}(2 \mathrm{x}) 300+ \\
400\end{array}$ \\
\hline & Nava & Juan de Otur & 60 \\
\hline & Siero & $\begin{array}{l}\text { Martín de Vigil de Santaolalla y Pedro Argüelles de } \\
\text { Meres }\end{array}$ & $450+500$ \\
\hline $\begin{array}{l}1597- \\
1598\end{array}$ & Nava & Alonso de Benegas y Toribio de Nava & $200+300$ \\
\hline 1599 & Oviedo & Diego de Carreño. & 900 \\
\hline \multirow[t]{2}{*}{1600} & Lena & Gabriel Ordóñez de Ujo & 300 \\
\hline & Oviedo & Sancho de Inclán Arango & 900 \\
\hline 1602 & Villaviciosa & Juan Fernández de la Venta & 181 \\
\hline
\end{tabular}




\begin{tabular}{|c|c|c|c|}
\hline AÑO & CONCEJO & COMPRADOR & $\begin{array}{l}\text { PRECIO } \\
\text { (DUCADOS) }\end{array}$ \\
\hline 1603 & Avilés & Sin datos & 300 \\
\hline \multirow[t]{2}{*}{1604} & Carreño & Bernardo de Valdés & $(2 x) 200$ \\
\hline & Piloña & Juan de la Villa & 230 \\
\hline 1608 & Castrillón & Sebastián de Inclán & 100 \\
\hline \multirow[t]{13}{*}{$1614^{*}$} & Aller & $\begin{array}{l}\text { D. Francisco Bernaldo de Quirós y Toribio de } \\
\text { Argüelles }\end{array}$ & (2x) 37 \\
\hline & Amieva & Toribio de Antayo & 25 \\
\hline & Avilés & $\begin{array}{l}\text { Gonzalo Alvarez de Bandujo, Pedro Menéndez de } \\
\text { Avilés, Pedro Menéndez de León Quirós, Pedro } \\
\text { Carrio, Pedro Alvarez de Valdés y Alvaro Peláez } \\
\text { Arango, Juan Martínez de Ponte, Andrés Alonso } \\
\text { de León, Juan de Valdés, Pedro Martínez de Puma- } \\
\text { rino y Melchor de Valdés y Da Inés de Grado }\end{array}$ & $(12 x) 75$ \\
\hline & Cangas de Tineo & $\begin{array}{l}\text { Diego García de Tineo y Llano y D. Suero Queipo } \\
\text { de Llano }\end{array}$ & $(2 \mathrm{x}) 100$ \\
\hline & Caso & $\begin{array}{l}\text { Andrés de Caso, Juan de Ceñal, Francisco Sánchez, } \\
\text { Juan Capa y Bernabé de Vigil el viejo (dos) }\end{array}$ & $(6 x) 33$ \\
\hline & Carreño & $\begin{array}{l}\text { Gabriel de Carrio, Diego González, Andrés Alonso, } \\
\text { Gabriel Bernardo y Miguel de Mendaño }\end{array}$ & $(5 x) 50$ \\
\hline & Castrillón & $\begin{array}{l}\text { Diego de Castrillón, Gonzalo Alvarez de Bandujo, } \\
\text { Pedro Galán de San Min, Pedro González Muñoz, } \\
\text { Luis Carvallo y Pedro Martínez Pumarino }\end{array}$ & $\begin{array}{r}(3 \mathrm{x}) \\
50+25+20 \\
+80 \\
\end{array}$ \\
\hline & Gijón & $\begin{array}{l}\text { Gregorio García de Tineo, Miguel Alvarez, Toribio } \\
\text { Argüelles de Celles, Alonso García Jove, Toribio de } \\
\text { Morán de Lavandera, Gonzalo Fernández, Fabián } \\
\text { Jove, Juan Vigil de Caldón, Julián García Jove y } \\
\text { Luis Carvallo }\end{array}$ & $(10 x) 80$ \\
\hline & Gozón & $\begin{array}{l}\text { Pedro Alvarez de Valdés, Rodrigo García de Puma- } \\
\text { rín, Juan González Romadonga y Domingo de la } \\
\text { Pola }\end{array}$ & $(4 x) 53$ \\
\hline & Laviana & D. Francisco Bernaldo de Quirós & 50 \\
\hline & Lena & $\begin{array}{l}\text { Gabriel de Argüelles, Diego de Argüelles de Vigil, } \\
\text { Sebastián Bernaldo de Quirós, Juan de Malleza, } \\
\text { Pedro Menéndez de Avilés, D. Rodrigo González } \\
\text { de Cienfuegos, D. Baltasar González de Cienfue- } \\
\text { gos, Alonso de Heredia, D. Fernando de Quirós, D. } \\
\text { Francisco Bernaldo, doctor Cosme de Valdés y Juan } \\
\text { de Valdés y Gabriel de Posada }\end{array}$ & $\begin{array}{r}(4 x) 100+ \\
(7 x)+75+ \\
(1 x) 67\end{array}$ \\
\hline & Miranda & $\begin{array}{l}\text { Juan Peláez de Leiguarda, Arias de Begega, Alonso } \\
\text { Cuervo de Llamero y Fernán García Doriga }\end{array}$ & $(4 x) 50$ \\
\hline & Parres & Toribio de Antayo y Lope de Junco & (2x) 32,5 \\
\hline
\end{tabular}

Hispania, LXIII/1, núm. 213 (2003) 75-136 


\begin{tabular}{|c|c|c|c|}
\hline AÑo & CONCEJO & COMPRADOR & $\begin{array}{c}\text { PRECIO } \\
\text { (DUCADOS) }\end{array}$ \\
\hline \multirow[t]{13}{*}{$1614 *$} & Oviedo & $\begin{array}{l}\text { Juan de Santiso Alvear, Andrés Carreño, licdo. } \\
\text { Julián de Miranda, Diego de Argüelles de Vega, } \\
\text { Alonso Bernardo de la Rúa, Gabriel de Argüelles, } \\
\text { Pedro de Quirós, Juan de Miranda, Toribio Argüe- } \\
\text { lles de Celles, Juan de Valdés Prada, Bernardo de } \\
\text { Heredia, Juan de Nora, Diego Carreño, doctor } \\
\text { Alonso de Solares, Lope Alvarez de Oviedo, doctor } \\
\text { Morán Bernardo, Luis Carvallo, Luis González de } \\
\text { Ribera, Alvaro de Salas y Fernán García de Doriga }\end{array}$ & $(20 x) 225$ \\
\hline & Piloña & $\begin{array}{l}\text { Juan González Manjón, Toribio Antayo, Tomás de } \\
\text { Caso, Diego de Caso de la Trapiella, Juan de Lada } \\
\text { y Pedro de Bada, Juan de la Villa, Domingo Sán- } \\
\text { chez Camargo y Juan de Pando }\end{array}$ & $\begin{array}{r}(5 x) 57+ \\
(4 x) 45\end{array}$ \\
\hline & Ponga & Tomás de Caso & 20 \\
\hline & Pravia & $\begin{array}{l}\text { Fernán García Doriga, Alvaro de Salas, Alonso } \\
\text { Cuervo Ponte, Alvaro Peláez Arango, Fernán Cuer- } \\
\text { vo de la Vimera y Pedro Menéndez de Avilés }\end{array}$ & $(6 x) 100$ \\
\hline & Ribadesella & $\begin{array}{l}\text { Juan de Bada, Pedro de Bada, Juan de Pando de } \\
\text { Sebreño y Domingo Sánchez de Camango }\end{array}$ & $(4 x) 55$ \\
\hline & Salas & $\begin{array}{l}\text { Fernan García de Doriga, Juan de Tuñón, Juan de } \\
\text { Malleza, Alvaro de Salas, Domingo Pérez de Dori- } \\
\text { ga, Juan Avello de Acellana, Alonso Méndez, Fer- } \\
\text { nando de Salas de Villamayor y Alonso de Francos }\end{array}$ & $(9 x) 50$ \\
\hline & Sariego & $\begin{array}{l}\text { Juan de Santiso Alvear y Bernabé de Vigil el viejo } \\
\text { (tres) }\end{array}$ & $(4 x) 50$ \\
\hline & Siero & $\begin{array}{l}\text { Juan de Santianes, capitán Bartolomé de Argüelles, } \\
\text { Gabriel de Argüelles, Lope Alvarez de Oviedo, } \\
\text { doctor Juan de Faes Valdés, Bernabé de Vigil, } \\
\text { Alonso Guergo de Valdés, Diego González Guer- } \\
\text { go, Toribio de Argüelles el soldado, Rodrigo de } \\
\text { Hevia, Juan de Nora, Luis González de Riera, } \\
\text { Bernabé de Vigil el viejo (dos) y Diego Argüelles de } \\
\text { Vega (dos) }\end{array}$ & $(12 x) 125$ \\
\hline & Somiedo & Alonso Cuervo del Lamero y D. Lope de Omaña & $(2 x) 31$ \\
\hline & Valdés & Toribio Argüelles de Celles & 50 \\
\hline & Villaviciosa & Juan Fernández de la Venta & 181 \\
\hline & Villaviciosa & Gonzalo de Peón y Bernabé de Vigil el viejo & $97+173$ \\
\hline & Villaviciosa & $\begin{array}{l}\text { Doctor Alonso de Solares, Rodrigo de Solares, } \\
\text { Pedro de Posada, Cosme de Solares, Gonzalo de } \\
\text { Peón y Gerónimo de Valdés }\end{array}$ & $(5 x) 75$ \\
\hline \multirow[t]{3}{*}{1615} & Cangas de Tineo & D. Lope de Omaña y D. Baltasar González & $(2 \mathrm{x}) 100$ \\
\hline & Colunga & Toribio Rodríguez de Bada & 39 \\
\hline & Oviedo & Alonso López de Oviedo & 225 \\
\hline
\end{tabular}




\begin{tabular}{|c|c|c|c|}
\hline AÑo & CONCEJO & COMPRADOR & $\begin{array}{l}\text { PRECIO } \\
\text { (DUCADOS) }\end{array}$ \\
\hline \multirow[t]{4}{*}{1615} & Pravia & D. Lope de Omaña & 100 \\
\hline & Ribadesella & Juan González Prieto & 55 \\
\hline & Somiedo & D. Lope de Omaña & 31 \\
\hline & Tineo & D. Lope de Omaña & 68 \\
\hline 1616 & Laviana & Miguel de León y Tomás García & $(2 x) 50$ \\
\hline \multirow[t]{18}{*}{1617} & Aller & $\begin{array}{l}\text { Sebastián Ordóñez del Pino y Fernando Ordóñez } \\
\text { del Pino }\end{array}$ & $(2 x) 37$ \\
\hline & Avilés & Lope de Miranda y Pedro Menéndez de Valdés & $(2 x) 75$ \\
\hline & Cabranes & $\begin{array}{l}\text { Diego de Argüelles de Vega y Alonso de Vega de } \\
\text { Nava }\end{array}$ & $(2 x) 13$ \\
\hline & Cangas de Onís & Juan de Labra & 62,5 \\
\hline & Cangas de Tineo & Diego García de Tineo & 100 \\
\hline & Carreño & Pedro de la Riba & 50 \\
\hline & Castrillón & Pedro de León Pola & 20 \\
\hline & Colunga & Gaspar de Valdés & 45 \\
\hline & Corvera & Sin datos & $(3 x) 25$ \\
\hline & Gozón & $\begin{array}{l}\text { D. Bernardo de Valdés (dos) y Domingo Suárez de } \\
\text { Hortal }\end{array}$ & $(3 x) 53$ \\
\hline & Lena & Toribio Alvárez de Cortina & 100 \\
\hline & Miranda & Lope de Miranda & 50 \\
\hline & Oviedo & Fernando de Valdés Bernardo y Lope de Miranda & $(2 x) 225$ \\
\hline & Pravia & $\begin{array}{l}\text { Diego García de Tineo, Gómez Arias de Ponte, } \\
\text { Diego Méndez de Acellana y Lope de Miranda }\end{array}$ & $\begin{array}{r}100+(2 x) \\
75+50\end{array}$ \\
\hline & Somiedo & Lope de Miranda (dos) & $(2 x) 31$ \\
\hline & Tineo & D. Lope de Omaña & 69 \\
\hline & Valdés & Antonio de Ron & 50 \\
\hline & Villaviciosa & Gaspar de Valdés & 75 \\
\hline \multirow{9}{*}{1618} & Carreño & Domingo Suárez de Hortal & 50 \\
\hline & Colunga & Juan de Faes Valdés & 45 \\
\hline & Grado & Rodrigo Ponce de Miranda & 38 \\
\hline & Laviana & Gonzalo de Argüelles de Celles & 50 \\
\hline & Lena & Martín Bernardo de Campomanes & 100 \\
\hline & Onís & Pedro de Posada & 37,5 \\
\hline & Oviedo & Fernando de Valdés Bernardo y Diego de Garín & $225+900$ \\
\hline & Siero & Lcdo Juan de Vigil & 125 \\
\hline & Valdés & Juan Avello y Pedro Avello de Trevías & $50+47,5$ \\
\hline \multirow[t]{4}{*}{1619} & Cangas de Tineo & Hernando García de Valcárcel & 100 \\
\hline & Carreño & Domingo de Valdés y Juan Muñiz Carreño & $(2 x) 50$ \\
\hline & Laviana & Gabriel de Argüelles & 50 \\
\hline & Nava & Francisco de Vigil y Juan de Castañeda & (2x) 28 \\
\hline
\end{tabular}

Hispania, LXIII/1, núm. 213 (2003) 75-136 


\begin{tabular}{|c|c|c|c|}
\hline AÑo & CONCEJO & COMPRADOR & $\begin{array}{l}\text { PRECIO } \\
\text { (DUCADOS) }\end{array}$ \\
\hline \multirow[t]{3}{*}{1619} & Ponga & Alonso Moniz y Juan Alonso Moniz & $(2 x) 20$ \\
\hline & Valdés & Lope Rico de Luarca & 50 \\
\hline & Villaviciosa & Gonzalo de Peón & 75 \\
\hline \multirow[t]{2}{*}{1620} & Colunga & Cosme Díaz de Cutre y Fernando de Covian de Briones & $(2 x) 45$ \\
\hline & Lena & Fabián Ordóñez de Ujo & 100 \\
\hline \multirow{6}{*}{$\begin{array}{l}1621- \\
1624\end{array}$} & Avilés & Toribio Argüelles de Celles & 85 \\
\hline & Colunga & Alonso Pérez del Rivero & 45 \\
\hline & Nava & Alvaro de Nava & 28 \\
\hline & Siero & Toribio Argüelles de Celles y Pedro Suárez de la Villa & $136+125$ \\
\hline & Valdés & Gómez Pertierra de Paredes & 50 \\
\hline & Gijón & $\begin{array}{l}\text { Francisco de Llanos, Alvaro de Valdés Llanos y } \\
\text { Juan de Valdés de Veranes }\end{array}$ & $80+(2 x) 88$ \\
\hline \multirow[t]{3}{*}{1625} & Nava & Domingo Alvarez de Nava (tres) y Bartolomé González & $(4 x) 75$ \\
\hline & Pravia & Sancho Inclán Arango & 120 \\
\hline & Siero & Mateo de Palacios y Santiago de Argüelles & $(2 \mathrm{x}) 150$ \\
\hline \multirow[t]{5}{*}{1630} & Avilés & Pedro Menéndez de León Quirós & 1.285 \\
\hline & Corvera & D. Boiso Suárez de Solís & 300 \\
\hline & Gijón & Licdo. Juan de Valdés & 1.836 \\
\hline & Oviedo & D. Francisco Bernaldo de Quirós & 2.700 \\
\hline & Tineo & Pedro de Francos de Arganza & 1.116 \\
\hline \multirow[t]{5}{*}{1631} & Corvera & D. Boiso Suarez de Solís & 30 \\
\hline & Pravia & D. Diego de Miranda & 700 \\
\hline & Ribadesella & D. Antonio de Estrada Manrique & 450 \\
\hline & Siero & Gregorio López Madera & 600 \\
\hline & Valdés & Juan García de Castrillón & 1.500 \\
\hline \multirow[t]{2}{*}{1632} & Aller & D. Francisco Bernaldo de Quirós & 400 \\
\hline & Aller & Fabián Ordóñez & 45 \\
\hline \multirow[t]{6}{*}{1633} & Cabranes & Toribio de Ribera & 100 \\
\hline & Cangas de Tineo & $\begin{array}{l}\text { D. Sancho de Miranda y D. Diego García de Tineo } \\
\text { y Llano }\end{array}$ & $220+1.000$ \\
\hline & Miranda & D. Sancho de Miranda & 520 \\
\hline & Onís & Pedro de Inguanzo & 87 \\
\hline & Somiedo & D. Sancho de Miranda & 220 \\
\hline & Villaviciosa & D. Pedro de Peón & 620 \\
\hline \multirow[t]{5}{*}{1634} & Amieva & Francisco de Meneses, guardamantel de S.M. & 272 \\
\hline & Cangas de Onís & Francisco de Meneses, guardamantel de S.M. & 500 \\
\hline & Nava & Bernabé de Vigil & 80 \\
\hline & Oviedo & Gregorio de Vigil & 2.600 \\
\hline & Salas & D. García de Doriga & 550 \\
\hline
\end{tabular}




\begin{tabular}{|c|c|c|c|}
\hline AÑO & CONCEJO & COMPRADOR & $\begin{array}{l}\text { PRECIO } \\
\text { (DUCADOS) }\end{array}$ \\
\hline 1634 & Valdés & Toribio Argüelles de Celles & 453 \\
\hline \multirow{25}{*}{$\begin{array}{l}1635- \\
1636\end{array}$} & Aller & D. Sebastián Bernaldo de Quirós & 400 \\
\hline & Avilés & D. Alvaro Flórez & 800 \\
\hline & Cabrales & Toribio González de Buerdo & 400 \\
\hline & Cabranes & D. Gutierre de Hevia & 180 \\
\hline & Cangas de Onís & $\begin{array}{l}\text { Pedro de Inguanzo, Fernando de Solís y Francisco } \\
\text { de Meneses }\end{array}$ & $(3 x) 500$ \\
\hline & Cangas de Tineo & Francisco de Sierra de Jarceley & 1.066 \\
\hline & Carreño & Licdo. D. Alvaro Flórez & 272 \\
\hline & Caso & Domingo de Piloña y Juan Alvarez de la Puente & $240+272$ \\
\hline & Colunga & Diego de Valdés Sorribas y Juan de la Villa & $(2 x) 280$ \\
\hline & Corvera & D. Pedro Menéndez León Quirós & 300 \\
\hline & Gijón & Bernabé de Vigil y capitán D. Pedro de Valdés & $(2 x) 600$ \\
\hline & Laviana & Juan Alvarez de la Puente & 317 \\
\hline & Lena & $\begin{array}{l}\text { D. Francisco Bernaldo de Quirós y D. Diego Ber- } \\
\text { naldo de Quirós }\end{array}$ & $500+700$ \\
\hline & Llanes & Francisco de Meneses, guardamantel de S.M. & 1.000 \\
\hline & Miranda & D. García de Doriga & 525 \\
\hline & Nava & $\begin{array}{l}\text { Juan de Palacios de Tiroco, Domingo Alvarez de } \\
\text { Nava y Lope de Junco }\end{array}$ & $\begin{array}{r}350+330 \\
+300 \\
\end{array}$ \\
\hline & Piloña & D. Pedro Duque de Estrada & 550 \\
\hline & Parres & Sebastián de Asiego & 260 \\
\hline & Ponga & Mateo de Argüelles y D. Juan de Caso & $(2 x) 136$ \\
\hline & Ribadesella & Lope de Junco y Juan de Palacios de Tiroco & $300+368$ \\
\hline & Salas & D. Sancho de Miranda Ponce & 600 \\
\hline & Sariego & Juan de Argüelles de Meres & 280 \\
\hline & Siero & D. Diego Bernaldo de Quirós & 901 \\
\hline & Somiedo & D. Sancho de Miranda Ponce & 220 \\
\hline & Villaviciosa & Alonso Balbín & 600 \\
\hline 1637 & Valdés & Licenciado D. Juan Avello y Valdés & 450 \\
\hline 1638 & Oviedo & D. Bartolomé Leiguarda & 3.300 \\
\hline \multirow[t]{5}{*}{1639} & Aller & Gregorio de Vigil & 400 \\
\hline & Avilés & Juan de León Falcón & 500 \\
\hline & Gijón & D. Pedro de Oviedo Valdés & 600 \\
\hline & Oviedo & D. Pedro Menéndez de León Quirós & 2.500 \\
\hline & Somiedo & Arias González y D. Sancho de Miranda & $(2 x) 250$ \\
\hline \multirow[t]{3}{*}{ 1640* } & Cangas de Tineo & Francisco de Sierra de Jarceley & 800 \\
\hline & Oviedo & D. Alonso Ramírez Jove & 1.815 \\
\hline & Valdés & D. Juan Avello y Valdés & 454 \\
\hline
\end{tabular}




\begin{tabular}{|c|c|c|c|}
\hline AÑo & CONCEJO & COMPRADOR & $\begin{array}{l}\text { PRECIO } \\
\text { (DUCADOS) }\end{array}$ \\
\hline \multirow[t]{3}{*}{1641} & Cabrales & Pedro de Mestas (dos) & $(2 x) 300$ \\
\hline & Oviedo & Toribio de Argüelles & 100 \\
\hline & Siero & Toribio Argüelles de Meres & 400 \\
\hline \multirow[t]{7}{*}{1642} & Avilés & $\begin{array}{l}\text { D. Antonio Díaz de Campomanes, Juan Falcón de } \\
\text { Arango, Diego de Valdés Bango, y Diego de Pren- } \\
\text { des Pola }\end{array}$ & $\begin{array}{r}400+454 \\
+500+545\end{array}$ \\
\hline & Carreño & $\begin{array}{l}\text { Félix de Prendes, Bernardo de Valdés Alas y Ber- } \\
\text { nardo de Valdés León }\end{array}$ & $\begin{array}{r}(2 \mathrm{x}) 200+ \\
362\end{array}$ \\
\hline & Gijón & Baltasar de Hevia Quiñones & 363 \\
\hline & Oviedo & Fernando de Valdés & 500 \\
\hline & Parres & Gonzalo Méndez & 280 \\
\hline & Ribadesella & D. Antonio de Estrada Manrique & 410 \\
\hline & Valdés & Fernando de Valdés & 500 \\
\hline \multirow[t]{2}{*}{1644} & Cabrales & García de Arenas & 150 \\
\hline & Oviedo & Pedro Cañedo Miranda & 1.045 \\
\hline \multirow[t]{4}{*}{1645} & Caravia & Gonzalo de Suero Díaz & 100 \\
\hline & Oviedo & $\begin{array}{l}\text { D. Alvaro de Faes y Valdés y Bartolomé Fernández } \\
\text { Ladreda }\end{array}$ & $(2 \mathrm{x}) 800$ \\
\hline & Parres & D. Francisco de Estrada & 273 \\
\hline & Ponga & $\begin{array}{l}\text { José de Caso, Juan Rato, Juan de Caso y Toribio de } \\
\text { Caso de Ponga }\end{array}$ & $(4 x) 100$ \\
\hline 1646 & Ribadesella & Consumo por la villa & 150 \\
\hline 1653 & Gijón & Juan Blanco & 600 \\
\hline 1654 & Cabranes & $\begin{array}{l}\text { Domingo González de la Fuente y Miguel Fernán- } \\
\text { dez de Bulnes }\end{array}$ & $(2 \mathrm{x}) 150$ \\
\hline
\end{tabular}

* 1562-1563. Las perpetuaciones de esta fecha fueron hechas a las personas propuestas por el corregidor del Principado, tras petición de la Corona. Ésta, para evitar costas a los compradores, mandó que se hicieran todos los trámites en Oviedo. No hemos encontrado registro de estas ventas en las secciones de Simancas y es posible que se produjera alguna variación mínima respecto a la nómina enviada por el corregidor, dado que hubo algunas protestas de agraviados por no estar en ella, así como peticiones de exclusión de algunos de los propuestos. Entre 1566 y 1581 nos consta que también compró un regimiento en Aller Alvaro Díaz de Bernaldo, 90 ducados.

* 1614. Algunos de los que constan como compradores de las perpetuaciones realizadas en este año y siguientes no lo son propiamente. Así, por ejemplo, cuatro de los regimientos de Caso no son propiedad de las cuatro personas que aparecen como titulares (Andrés de Caso, Juan de Ceñal, Francisco Fernández y Juan Capa), sino de Diego Caso de la Trapiella, que los tiene en su cabeza.

* En los años cuarenta y cincuenta se vendió a muchos regidores de Oviedo la calidad de poner tenientes, aunque no nos consta precio ni fecha. Sabemos que en 1654 la ciudad resumió siete tenencias en 1.874 ds. (las de D.Antonio Ramírez de Jove, D.Toribio Argüelles, D.Francisco de Llanos Jove, D.Domingo Alvarez Nalón, D.Fernando de Valdés, D.Baltasar de Prada y D.Bernabé de Vigil). Años después se resumen otras veintiuno, cuyo gasto se estimó en 1.524 ds.: son las del marqués de Camposagrado (dos), D.Antonio Flórez, D.Alonso A. de Heredia, D.Francisco de Hevia, D.Francisco de Peón, D.Pedro Alvarez Santianes, conde de Peñalba, D.Gaspar González de Candamo, D.Toribio Carbajal, D.Juan Alvarez de Grado, D.Alvaro de Hevia, D.Sancho de Inclán, D.Baltasar de Caso, marqués de Valdecarzana, D.Lázaro Cañedo, D.Diego Dasmarinas, D.Felipe Bernardo Ladreda, D.Pedro Solís, D.Felipe Rato y D.Francisco de Llanes. 


\section{CUADRO 3. OTROS OFICIOS VENDIDOS EN ASTURIAS DURANTE LOS SIGLOS XVI Y XVII}

\begin{tabular}{|c|c|c|c|c|}
\hline AÑO & CONCEJO & OFICIO & COMPRADOR & $\begin{array}{l}\text { PRECIO } \\
\text { (DUCADOS) }\end{array}$ \\
\hline \multirow[t]{2}{*}{1557} & $\begin{array}{l}\text { Candamo (alfoz } \\
\text { de Grado) }\end{array}$ & $\begin{array}{l}\text { Alférez } \\
\text { perpetuo }\end{array}$ & Lope de Estrada & 200 \\
\hline & Grado & Id. & D. Hernando de Valdés & 250 \\
\hline \multirow[t]{22}{*}{1558} & Aller & Id. & Capitán Pedro Bernaldo de Quirós & 300 \\
\hline & Avilés & Id. & Martín de las Alas & 700 \\
\hline & Cabranes & Id. & Hernando de Valdés & 350 \\
\hline & Cangas de Onís & Id. & Hernando de Estrada & 300 \\
\hline & Caravia & Id. & Juan de Cutre (renuncia en Jo de Suero Díaz) & 300 \\
\hline & Carreño & Id. & Alonso Carreño & 300 \\
\hline & Castrillón & Id. & Alvaro Carreño & 300 \\
\hline & Colunga & Id. & Rodrigo de Junco & 300 \\
\hline & Corvera & Id. & Martín de Bango & 300 \\
\hline & Gijón & Id. & Juan García de Jove & 400 \\
\hline & Gozón & Id. & $\begin{array}{l}\text { Pedro García de Jove (pasó a Rui Gonzá- } \\
\text { lez de la Pola) }\end{array}$ & 375 \\
\hline & Lena & Id. & Rodrigo Bernaldo de Miranda & 300 \\
\hline & Onís & Id. & Juan de Estrada & 300 \\
\hline & Oviedo & Id. & D. Pedro de Solís & 1.000 \\
\hline & Parres & Id. & Rodrigo de Nevares & 300 \\
\hline & Piloña & Id. & Alvar Pérez de Espinaredo & 330 \\
\hline & Pravia & Id. & Garci González Barbón & 330 \\
\hline & Ribadesella & Id. & Rodrigo de Junco, criado de S.M. & 300 \\
\hline & Sariego & Id. & Menendo de Marines & 300 \\
\hline & Siero & Id. & Diego de Santillana & 300 \\
\hline & Somiedo & Id. & Sancho de Miranda & 300 \\
\hline & Villaviciosa & Id. & $\begin{array}{l}\text { Francisco de la Loma, criado del secreta- } \\
\text { rio Juan Vázquez de Molina }\end{array}$ & 330 \\
\hline $\begin{array}{l}1562- \\
1563\end{array}$ & Oviedo & $\begin{array}{l}\text { Procurado- } \\
\text { res de } \\
\text { número }\end{array}$ & $\begin{array}{l}\text { Gonzalo de Vigil, Bartolomé de San } \\
\text { Miguel, Andrés Rodríguez de la Roza, } \\
\text { Pedro de Pravia, Martín de Uceda, Ga- } \\
\text { briel de Hevia, Pedro García de Soto, } \\
\text { Andrés de Barrio, Fernán Menéndez de } \\
\text { Posada y Andrés Suárez }\end{array}$ & Sin datos \\
\hline 1563 & Oviedo & $\begin{array}{l}\text { Depositario } \\
\text { general }\end{array}$ & Nicolás de Ania & 750 \\
\hline $1566 *$ & Avilés & $\begin{array}{l}\text { Depositario } \\
\text { gral y recep- } \\
\text { tor de penas } \\
\text { de cámara }\end{array}$ & Rodrigo de las Alas & 200 \\
\hline
\end{tabular}

Hispania, LXIII/1, núm. 213 (2003) 75-136 


\begin{tabular}{|c|c|c|c|c|}
\hline AÑo & CONCEJO & OfICIO & COMPRADOR & $\begin{array}{c}\text { PRECIO } \\
\text { (DUCADOS) }\end{array}$ \\
\hline \multirow[t]{7}{*}{$1566^{*}$} & Carreño & Id. & Benito Carreño & 130 \\
\hline & Gijón & Id. & D. Pedro de Valdés & 130 \\
\hline & Cangas de Onís & Id. & Gutierre Alonso de Intriago & 100 \\
\hline & Lena & Id. & Sebastián Bernaldo de Quirós & 130 \\
\hline & Onís & Id. & $\begin{array}{l}\text { Pedro González de Villar (pasó a Diego } \\
\text { Hernández de Intriago) }\end{array}$ & 86 \\
\hline & Pravia & Id. & Hernando Cuervo & 173 \\
\hline & Siero & Id. & Lcdo. Juan de Estrada & 130 \\
\hline \multirow[t]{5}{*}{1567} & Corvera & Id. & Luis Alonso de León & 80 \\
\hline & Gozón & Id. & Simón de León de Quirós & 133 \\
\hline & Sariego & Id. & Pedro Sánchez del Valle & 80 \\
\hline & Ribadesella & Id. & Gonzalo de Junco & 120 \\
\hline & Villaviciosa & Id. & Martín Montes de Vigil & 150 \\
\hline 1567 & Principado & $\begin{array}{l}\text { Tesorero de } \\
\text { las rentas } \\
\text { reales }\end{array}$ & $\begin{array}{l}\text { Juan de Robles (pasó a Juan de Carrio } \\
\text { Valdés y luego a Fernando.de Valdés } \\
\text { Bernardo }\end{array}$ & 2.035 \\
\hline 1572 & Principado & $\begin{array}{l}\text { Procurador } \\
\text { de número }\end{array}$ & Ǵonzalo Pantiga & 150 \\
\hline \multirow[t]{5}{*}{1573} & Onís & $\begin{array}{l}\text { Depositario } \\
\text { general. }\end{array}$ & Juan González Cebos & 60 \\
\hline & Oviedo & \begin{tabular}{|l}
$\begin{array}{l}\text { Fieles eje- } \\
\text { cutores }\end{array}$ \\
\end{tabular} & Ocho (tanteados por la ciudad en 1578 ) & $(8 \times 200)$ \\
\hline & Oviedo & $\begin{array}{l}\text { Procurado- } \\
\text { res de } \\
\text { número } \\
\end{array}$ & $\begin{array}{l}\text { Diego Martínez de Casamayor, Diego } \\
\text { Alvarez de Lena y Tomás de Avilés }\end{array}$ & $(3 x) 150$ \\
\hline & Oviedo & $\begin{array}{l}\text { Fieles eje- } \\
\text { cutores }\end{array}$ & $\begin{array}{l}\begin{array}{l}\text { Pedro de Argüelles y Juan de Argüelles } \\
\text { (tanteados por la ciudad) }\end{array} \\
\end{array}$ & $(2 x) 800$ \\
\hline & Carreño & $\begin{array}{l}\text { Fiel ejecu- } \\
\text { tor }\end{array}$ & Juan de Argüelles (lo resume el concejo) & 375 \\
\hline 1581 & Oviedo & $\begin{array}{l}\text { Alcaide de } \\
\text { la cárcel }\end{array}$ & Toribio de la Ribera & 1.500 \\
\hline \multirow[t]{4}{*}{$\begin{array}{l}1583- \\
1584\end{array}$} & Cabrales & $\begin{array}{l}\text { Alférez } \\
\text { mayor }\end{array}$ & García Sánchez de Bárzana & 700 \\
\hline & Salas & Id. & $\begin{array}{l}\text { D. Hernando Osorio de Valdés, señor de } \\
\text { Valdonquillo }\end{array}$ & 500 \\
\hline & Tineo & Id. & Diego García de Tineo & 750 \\
\hline & Valdés & Id. & Alvaro Pérez de Navia y Arango & 600 \\
\hline \multirow[t]{3}{*}{$\begin{array}{l}1583- \\
1584\end{array}$} & Aller & $\begin{array}{l}\text { Depositaría } \\
\text { general }\end{array}$ & Gutierre Bernaldo de Quirós & 250 \\
\hline & Cabrales & Id. & Gómez Pérez de Arenas el mozo & 201 \\
\hline & Carreño & Id. & Benito Carreño & 150 \\
\hline
\end{tabular}




\begin{tabular}{|c|c|c|c|c|}
\hline AÑO & CONCEJO & Oficio & COMPRADOR & $\begin{array}{l}\text { PRECIO } \\
\text { (DUCADOS) }\end{array}$ \\
\hline \multirow{8}{*}{$\begin{array}{l}1583- \\
1584\end{array}$} & Castrillón & Id. & Juan de León Falcón & 100 \\
\hline & Colunga & Id. & Josepe Alonso Rivero & 140 \\
\hline & Laviana & Id. & Diego Morán el mozo & 120 \\
\hline & Parres & Id. & Bernardo de Estrada de Nevares & 140 \\
\hline & Salas & Id. & García de Valdés & 180 \\
\hline & Somiedo & Id. & Alvaro Flórez & 110 \\
\hline & Tineo & Id. & Juan García de Tineo & 350 \\
\hline & Valdés & Id. & Sancho Méndez el mozo & 300 \\
\hline \multirow[t]{7}{*}{$\begin{array}{l}1585- \\
1586\end{array}$} & Avilés & $\begin{array}{l}\text { Alférez } \\
\text { mayor }\end{array}$ & Juan de Aguirre & 150 \\
\hline & Llanes & \begin{tabular}{|l|}
$\begin{array}{l}\text { Depositaría } \\
\text { general }\end{array}$ \\
\end{tabular} & Hernando de Posada & 250 \\
\hline & Llanes & $\begin{array}{l}\text { Alférez } \\
\text { mayor }\end{array}$ & Juan de Posada & 600 \\
\hline & Miranda & Id. & Diego Flórez de Valdés & 430 \\
\hline & Nava & Id. & Bernabé Vigil & 330 \\
\hline & Miranda & \begin{tabular}{|l|} 
Depositaría \\
\end{tabular} & Fernando Alvarez de Leiguarda & 100 \\
\hline & Piloña & Id. & Juan de Mones & 200 \\
\hline \multirow[t]{3}{*}{$\begin{array}{l}1587- \\
1588\end{array}$} & $\begin{array}{l}\text { Cangas de } \\
\text { Tineo }\end{array}$ & $\begin{array}{l}\text { Alférez } \\
\text { mayor }\end{array}$ & D. Hernando Osorio de Valdés & 3.000 \\
\hline & Caso & Id. & Gutierre Bernaldo de Caso & 400 \\
\hline & Oviedo & $\begin{array}{l}\begin{array}{l}\text { Depositaría } \\
\text { general }\end{array} \\
\end{array}$ & Pedro Alonso de Ania & 400 \\
\hline \multirow[t]{2}{*}{$\begin{array}{l}1587- \\
1588\end{array}$} & $\begin{array}{l}\text { Cangas de } \\
\text { Tineo }\end{array}$ & Depositario & Capitán Diego García de Sierra & 450 \\
\hline & Nava & Id. & $\begin{array}{l}\text { Antonio de Argüelles (vacó en } 1597 \text { y la } \\
\text { compró Francisco de Nevares en } 200 \text { ds.) }\end{array}$ & 150 \\
\hline 1590 & Ponga & $\begin{array}{l}\text { Alférez } \\
\text { mayor }\end{array}$ & Alvaro de Caso & 460 \\
\hline 1593 & Principado & \begin{tabular}{|l|} 
Tesorero de \\
alcabalas y \\
tercias
\end{tabular} & Gabriel Valenciano & 1.000 \\
\hline 1596 & Pravia & Depositario & Fernando de Salas & 500 \\
\hline 1596 & Siero & \begin{tabular}{|l|}
$\begin{array}{l}\text { Alcaide } \\
\text { cárcel }\end{array}$ \\
\end{tabular} & Gonzalo de Argüelles de Celles & 300 \\
\hline 1597 & Gijón & Id. & Diego de Valdés Miranda & 250 \\
\hline \multirow[t]{2}{*}{1597} & Caso & Depositario & Pedro de Buyeres & 200 \\
\hline & Nava & Depositario & Francisco de Nevares & 200 \\
\hline 1600 & Principado & $\begin{array}{l}\text { Tesorero } \\
\text { rentas reales }\end{array}$ & Simón de Vigil & 1.700 \\
\hline
\end{tabular}




\begin{tabular}{|c|c|c|c|c|}
\hline AÑO & CONCEJO & OFICIO & COMPRADOR & $\begin{array}{c}\text { PRECIO } \\
\text { (DUCADOS) }\end{array}$ \\
\hline 1608 & Principado & $\begin{array}{l}\text { Tesorero } \\
\text { rentas } \\
\text { reales } \\
\end{array}$ & Sebastián Inclán & 1.700 \\
\hline 1608 & Pravia & $\begin{array}{l}\text { Alcaide } \\
\text { cárcel }\end{array}$ & Sebastián de Inclán & 100 \\
\hline 1611 & Piloña & $\begin{array}{l}\text { Alcaide } \\
\text { cárcel }\end{array}$ & Fernando de Covián & 300 \\
\hline \multirow[t]{2}{*}{1612} & Oviedo & $\begin{array}{l}\text { Depositario } \\
\text { de fuentes } \\
\text { y puentes }\end{array}$ & Juan Rato de Argüelles (sin voz ni voto) & 400 \\
\hline & Siero & Depositario & Antonio de Estrada & 250 \\
\hline 1613 & Ribadesella & $\begin{array}{l}\text { Alcaide } \\
\text { cárcel }\end{array}$ & Gaspar de Covián & 180 \\
\hline \multirow[t]{12}{*}{1614} & Aller & Depositario & $\begin{array}{l}\text { Gutierre Bernaldo de Quirós, señor casa } \\
\text { de Quirós }\end{array}$ & 187 \\
\hline & Colunga & Id. & Alonso de Heredia & 226 \\
\hline & Laviana & Id. & Sebastián Bernaldo de Quirós & 250 \\
\hline & Lena & Id. & D. Francisco Bernaldo de Quirós & 500 \\
\hline & Oviedo & $\begin{array}{l}\text { Alcaide } \\
\text { cárcel y } \\
\text { fortaleza del } \\
\text { Principado }\end{array}$ & Doctor Bernardo de Heredia & 287 \\
\hline & Piloña & $\begin{array}{l}\text { Fiel almo- } \\
\text { tacen }\end{array}$ & Toribio de Antayo & 86 \\
\hline & Piloña & $\begin{array}{l}\text { Corredor } \\
\text { perpetuo }\end{array}$ & Toribio de Antayo & 50 \\
\hline & Piloña & $\begin{array}{l}\text { Procurador } \\
\text { del concejo }\end{array}$ & Toribio de Antayo (dos) & 132 \\
\hline & Principado & $\begin{array}{l}\text { Merino } \\
\text { mayor del } \\
\text { Principado }\end{array}$ & D. Francisco de la Torre & Sin datos \\
\hline & Ribadesella & Depositario & Juan González Prieto & 120 \\
\hline & Siero & Depositario & Antonio de Estrada & 95 \\
\hline & Villaviciosa & Alcaide & Gonzalo de Peón & Sin datos \\
\hline \multirow[t]{5}{*}{1617} & Colunga & Depositario & Alonso de Heredia & 226,5 \\
\hline & Gijón & $\begin{array}{l}\text { Procurador } \\
\text { de causas }\end{array}$ & $\begin{array}{l}\text { Gregorio García de Tineo y Andrés } \\
\text { García de Castro }\end{array}$ & $(2 x) 50$ \\
\hline & Miranda & Depositario & Casa de Leiguarda & Sin datos \\
\hline & Oviedo & $\begin{array}{l}\text { Fieles eje- } \\
\text { cutores }\end{array}$ & $\begin{array}{l}\text { Sin datos (tanteados por la ciudad de } \\
\text { Oviedo) }\end{array}$ & 400 \\
\hline & Oviedo & $\begin{array}{l}\text { Alcaide } \\
\text { cárcel y } \\
\text { merindad }\end{array}$ & Dr. D. Alonso de Solares & 200 \\
\hline
\end{tabular}




\begin{tabular}{|c|c|c|c|c|}
\hline AÑo & CONCEJO & OfICIO & COMPRADOR & $\begin{array}{c}\text { PRECIO } \\
\text { (DUCADOS) }\end{array}$ \\
\hline \multirow[t]{3}{*}{1617} & Piloña & $\begin{array}{l}\text { Procurado- } \\
\text { res de } \\
\text { causas }\end{array}$ & Alonso de Heredia y Toribio de Antayo & $(2 \mathrm{x}) 125$ \\
\hline & Piloña & $\begin{array}{l}\text { Fiel almo- } \\
\text { tacén }\end{array}$ & Alonso Gómez de Caso & 87 \\
\hline & Pravia & $\begin{array}{l}\text { Fiel almo- } \\
\text { tacén }\end{array}$ & Alvaro Peláez de Arango & 60 \\
\hline \multirow[t]{2}{*}{1618} & Siero & $\begin{array}{l}\text { Alcaide } \\
\text { cárcel }\end{array}$ & D. Gonzalo Argüelles de Celles & 75 \\
\hline & Villaviciosa & $\begin{array}{l}\text { Procurado- } \\
\text { res }\end{array}$ & $\begin{array}{l}\text { Cosme de Peón (dos) ( renuncia a favor } \\
\text { del concejo) }\end{array}$ & $(2 \mathrm{x}) 100$ \\
\hline \multirow[t]{4}{*}{1619} & Gijón & $\begin{array}{l}\text { Procurado- } \\
\text { res }\end{array}$ & $\begin{array}{l}\text { Alejandro del Busto y Andrés García de } \\
\text { Castro }\end{array}$ & $(2 x) 50$ \\
\hline & Oviedo & $\begin{array}{l}\text { Almotace- } \\
\text { nes }\end{array}$ & Ciudad de Oviedo & 300 \\
\hline & Oviedo & $\begin{array}{l}\text { Procurado- } \\
\text { res }\end{array}$ & $\begin{array}{l}\text { Toribio Fernandez del Villar, Domingo } \\
\text { Rodríguez de la Torre, Gabriel de Posa- } \\
\text { da, Gabriel de Buelga, Alvaro García de } \\
\text { Riaño, Simón de Vigil, Juan Rato Argüe- } \\
\text { lles, Gabriel González Valle, Juan Rodrí- } \\
\text { guez de la Torre, Alonso de Llamas, Blas } \\
\text { de Pravia y Gabriel de Argüelles }\end{array}$ & $\begin{array}{c}(12 \mathrm{x}) \\
275\end{array}$ \\
\hline & Salas & $\begin{array}{l}\text { Fiel ejecu- } \\
\text { toría }\end{array}$ & El concejo & 40 \\
\hline \multirow[t]{4}{*}{1620} & Avilés & Procurador & La villa & 100 \\
\hline & \begin{tabular}{|l|} 
Cangas de \\
Tineo \\
\end{tabular} & $\begin{array}{l}\text { Procurado- } \\
\text { res }\end{array}$ & El concejo & 226 \\
\hline & Oviedo & Depositario & Juan Rato de Argüelles & 100 \\
\hline & Ribadesella & $\begin{array}{l}\text { Fiel almo- } \\
\text { tacén }\end{array}$ & Toribio Rodríguez & 82,5 \\
\hline \multirow[t]{2}{*}{1621} & Avilés & Corredor & La villa & 100 \\
\hline & Avilés & $\begin{array}{l}\text { Fiel almo- } \\
\text { tacen }\end{array}$ & La villa & 150 \\
\hline \multirow[t]{3}{*}{$\begin{array}{l}1622- \\
1623\end{array}$} & Avilés & $\begin{array}{l}\text { Depositario } \\
\text { general. }\end{array}$ & Luis de Carvallo (por una vida) & 160 \\
\hline & Gijón & Receptor & Juan de Valdés & 88 \\
\hline & Gozón & Id. & Sebastián Alvarez de Valdés & 53 \\
\hline 1628 & Llanes & $\begin{array}{l}\text { Alcaide } \\
\text { fortaleza }\end{array}$ & $\begin{array}{l}\text { D. Fernán Duque de Estrada (se le per- } \\
\text { petuó en 1636) }\end{array}$ & $\begin{array}{r}0 \\
\text { (merced) } \\
\end{array}$ \\
\hline 1630 & Pravia & $\begin{array}{l}\text { Alcaide } \\
\text { fortaleza }\end{array}$ & $\begin{array}{l}\text { D. Diego de Miranda (perpetuada a su } \\
\text { hijo D. Sancho de Miranda en 1633) }\end{array}$ & 200 \\
\hline
\end{tabular}




\begin{tabular}{|c|c|c|c|c|}
\hline AÑO & CONCEJO & OFICIO & COMPRADOR & $\begin{array}{c}\text { PRECIO } \\
\text { (DUCADOS) }\end{array}$ \\
\hline \multirow[t]{2}{*}{1631} & Amieva & $\begin{array}{l}\text { Fiel almo- } \\
\text { tacen }\end{array}$ & Toribio de Antayo & 30 \\
\hline & Pravia & Receptor & D. Sancho de Miranda & 700 \\
\hline 1634 & Ribadesella & $\begin{array}{l}\text { Alguacil } \\
\text { mayor }\end{array}$ & Capitán D. Pedro de Valdés Junco & 362 \\
\hline \multirow[t]{9}{*}{1635} & Aller & $\begin{array}{l}\text { Alguacil } \\
\text { mayor }\end{array}$ & $\begin{array}{l}\text { Juan Fernandez Mirón (criado de Sebas- } \\
\text { tián Bernaldo de Quirós) }\end{array}$ & 600 \\
\hline & Colunga & Id. & Capitán D. Alonso de Balbín & 480 \\
\hline & Gijón & Id. & D. Juan de Valdés Tineo & 900 \\
\hline & Laviana & Id. & Gabriel González de Valdés & 650 \\
\hline & Lena & Id. & Diego Bernaldo de Quirós & 1.150 \\
\hline & Oviedo & Id. & D. Sebastián Bernaldo de Quirós & 3.000 \\
\hline & Piloña & Id. & Juan Alvarez de Coya & 950 \\
\hline & Siero & Id. & $\begin{array}{l}\text { Bernardo de Asón Hevia (renuncia en Lope } \\
\text { de Argüelles Vega y Quiñones en 1637) }\end{array}$ & 1.000 \\
\hline & Villaviciosa & Id. & Diego de Valdés de Sorriba & 1.441 \\
\hline \multirow[t]{4}{*}{1636} & Oviedo & $\begin{array}{l}\text { Tesorero de } \\
\text { millones }\end{array}$ & Juan López Leonel & 3.301 \\
\hline & $\begin{array}{l}\text { Avilés y sus } \\
\text { concejos }\end{array}$ & $\begin{array}{l}\text { Alguacil } \\
\text { mayor }\end{array}$ & Capitán Bernardo de Valdés Alas & 1.995 \\
\hline & Caso & $\begin{array}{l}\text { Alguacil } \\
\text { mayor }\end{array}$ & Bernardo de Asón Hevia & 600 \\
\hline & Principado & $\begin{array}{l}\text { Alférez } \\
\text { mayor del } \\
\text { Principado }\end{array}$ & D. Alvaro Queipo de Llano & 5.280 \\
\hline 1637 & Oviedo & $\begin{array}{l}\text { Alcaide } \\
\text { mayor }\end{array}$ & Pedro de Leiguarda & 3.300 \\
\hline 1637 & Principado & $\begin{array}{l}20 \text { Procu- } \\
\text { radores }\end{array}$ & Consumo por el Principado & 1.088 \\
\hline \multirow[t]{4}{*}{1639} & Carreño & $\begin{array}{l}\text { Alguacil } \\
\text { mayor }\end{array}$ & D. Alonso Carreño de las Alas & 362 \\
\hline & Caso & $\begin{array}{l}\text { Alguacil } \\
\text { mayor }\end{array}$ & Bernardo de Asón Hevia & 600 \\
\hline & Oviedo & $\begin{array}{l}\text { Contador } \\
\text { de millones }\end{array}$ & $\begin{array}{l}\text { D. Fernando de Valdés, cartero mayor de } \\
\text { las estafetas de Castilla y Andalucía }\end{array}$ & 2.540 \\
\hline & Pravia & Id. & D. Alonso Carreño de las Alas & 1.000 \\
\hline \multirow[t]{2}{*}{1640} & $\begin{array}{l}\text { Cangas de } \\
\text { Tineo }\end{array}$ & Id. & D. Diego Queipo de Llano y Flórez & 1.632 \\
\hline & Parres & $\begin{array}{l}\text { Alguacil } \\
\text { mayor }\end{array}$ & $\begin{array}{l}\text { Francisco Rodríguez de Acevedo (se } \\
\text { ejecutó por impago y compró } \mathrm{D}^{\mathrm{a}} \text { Isabel } \\
\text { de Valdés, viuda de D. Diego de Estrada } \\
\text { en } 401 \text { ducados) }\end{array}$ & 544 \\
\hline
\end{tabular}

Hispania, LXIII/1, núm. 213 (2003) 75-136 


\begin{tabular}{|c|c|c|c|c|}
\hline AÑ̃ & CONCEJO & OfICIO & COMPRADOR & $\begin{array}{c}\text { PRECIO } \\
\text { (DUCADOS) }\end{array}$ \\
\hline 1641 & Avilés & $\begin{array}{l}\text { Alcaide de } \\
\text { las dos } \\
\text { fortalezas }\end{array}$ & $\begin{array}{l}\text { D. Martín Menéndez de Avilés (perpe- } \\
\text { tuado en 1644) }\end{array}$ & $\begin{array}{r}0 \\
\text { (merced) }\end{array}$ \\
\hline \multirow[t]{6}{*}{1642} & Avilés & Depositario & D. Sancho de Miranda & 136 \\
\hline & Gijón & $\begin{array}{l}\text { Procurador } \\
\text { gral., síndi- } \\
\text { co y } \\
\text { personero }\end{array}$ & Gonzalo Tineo Solís & 400 \\
\hline & Parres & $\begin{array}{l}\text { Alcaide } \\
\text { cárcel }\end{array}$ & D. Francisco de Estrada & 272 \\
\hline & Siero & $\begin{array}{l}\text { Procurador } \\
\text { gral., síndi- } \\
\text { co y } \\
\text { personero }\end{array}$ & Juan Argüelles de Meres & 1.000 \\
\hline & Carreño & $\begin{array}{l}\text { Fiel ejecu- } \\
\text { tor }\end{array}$ & D. Baltasar de Villabona & 200 \\
\hline & Oviedo & Alcalde & Juan Covián & 181 \\
\hline \multirow[t]{2}{*}{1646} & $\begin{array}{l}\text { Cangas de } \\
\text { Tineo }\end{array}$ & $\begin{array}{l}\text { Fiel ejecu- } \\
\text { tor y guar- } \\
\text { da del } \\
\text { campo } \\
\end{array}$ & D. Arias de Omaña & 500 \\
\hline & Parres & $\begin{array}{l}\text { Alguacil } \\
\text { mayor }\end{array}$ & Diego de Valdés & 418 \\
\hline 1664 & Parres & $\begin{array}{l}\text { Contador } \\
\text { de parti- } \\
\text { ciones }\end{array}$ & Toribio González de los Corrales & Sin datos \\
\hline 1668 & $\begin{array}{l}\text { Prdo. Asturias } \\
\text { y Cuatro Villas } \\
\text { Costa de la Mar }\end{array}$ & $\begin{array}{l}\text { Superint. } \\
\text { de fábrica, } \\
\text { montes y } \\
\text { plantíos }\end{array}$ & D. Domingo Herrera de la Concha & 27.000 \\
\hline
\end{tabular}

* Entre 1566 y 1581 se vendió también la depositaría de Parres a Juan de Estrada en 40 ds. 